Nevada

Environmental

Restoration

Project

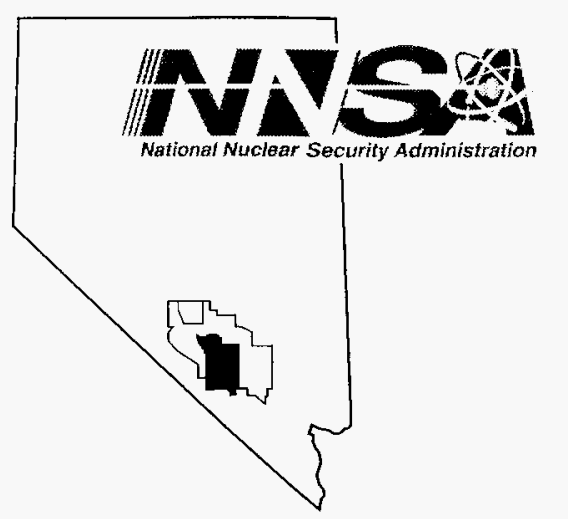

Post-Closure Inspection and Monitoring Report for Corrective Action Unit 110: Area 3 WMD U-3ax/bl Crater, Nevada Test Site, Nevada For the Period July 2004 June 2005

Controlled Copy No.:

Revision: 0

August 2005

Environmental Restoration

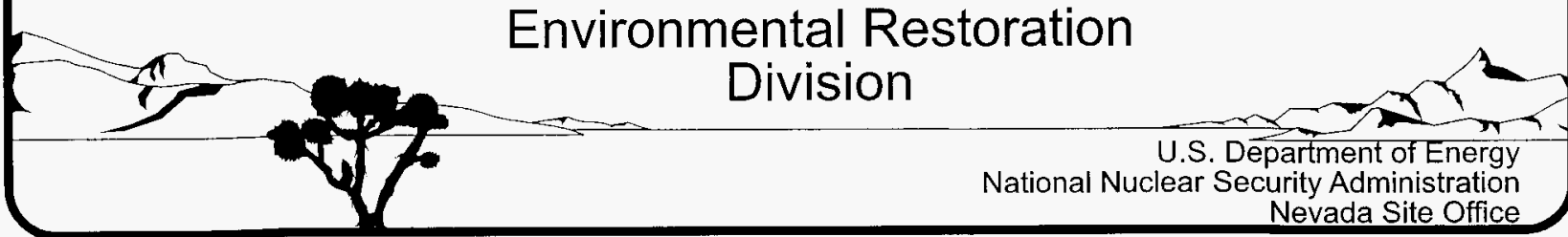




\section{DISCLAIMER}

Reference herein to any specific commercial product, process, or service by trade name, trademark, manufacturer, or otherwise, does not necessarily constitute or imply its endorsement, recommendation, or favoring by the United States Government or any agency thereof or its contractors or subcontractors.

This report has been reproduced directly from the best available copy.

Available for sale to the public from:

U.S. Department of Commerce

National Technical Information Service

5285 Port Royal Road

Springfield, VA 22161-0002

Telephone: (800) 553-6847

Fax: (703) 605-6900

E-mail: orders@ntis.gov

Online ordering: http:/www.ntis.gov/ordering.htm

Available electronically at http://www.osti.gov/bridge.

Available for a processing fee to the U.S. Department of Energy and its contractors, in paper, from:

U.S. Department of Energy

Office of Scientific and Technical Information

P.O. Box 62

Oak Ridge, TN 37831-0062

Telephone: (865) 576-8401

Fax: (865) 576-5728

E-mail: reports@adonis.osti.gov 


\title{
POST-CLOSURE INSPECTION AND MONITORING REPORT FOR CORRECTIVE ACTION UNIT 110: \\ AREA 3 WMD U-3ax/bl CRATER, NEVADA TEST SITE, NEVADA
}

\author{
FOR THE PERIOD \\ JULY 2004 - JUNE 2005
}

\author{
U.S. Department of Energy \\ National Nuclear Security Administration \\ Nevada Site Office \\ Las Vegas, Nevada
}

Controlled Copy No.

Revision: 0

August 2005 


\section{THIS PAGE INTENTIONALLY LEFT BLANK}




\title{
POST-CLOSURE INSPECTION AND MONITORING REPORT FOR CORRECTIVE ACTION UNIT 110: AREA 3 WMD U-3ax/bl CRATER, NEVADA TEST SITE, NEVADA
}

\author{
FOR THE PERIOD \\ JULY 2004 - JUNE 2005
}

Approved By: Sabine Cortis Date: 8/23/05 Industrial Sites Project

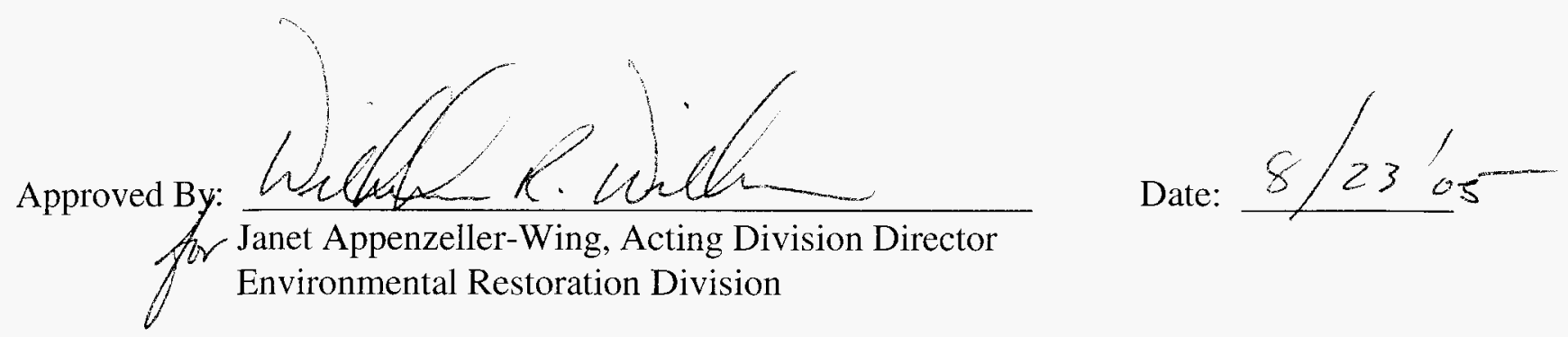


THIS PAGE INTENTIONALLY LEFT BLANK 


\section{TABLE OF CONTENTS}

ACRONYMS AND ABBREVIATIONS ……..................................................................... vii

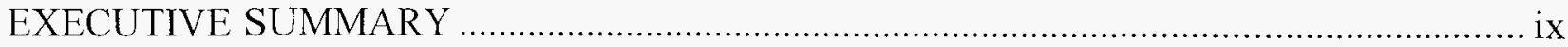

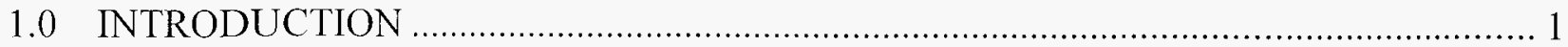

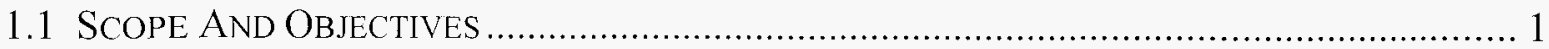

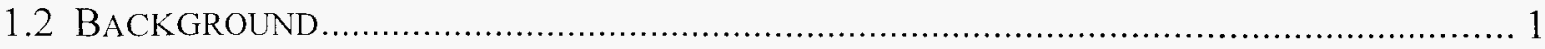

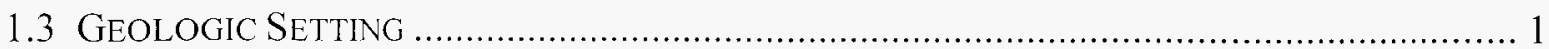

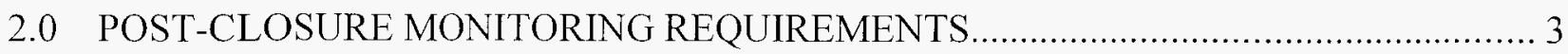

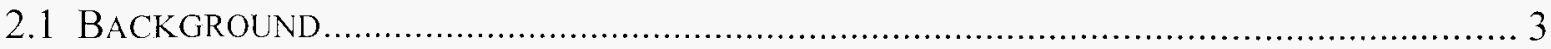

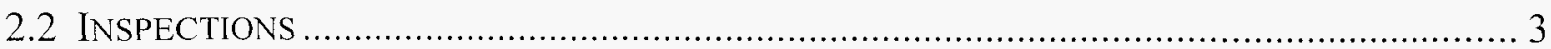

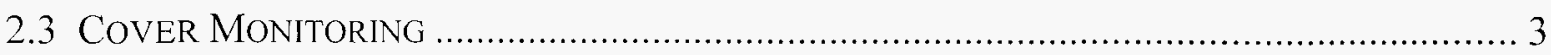

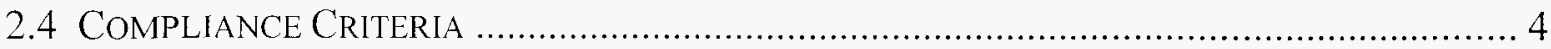

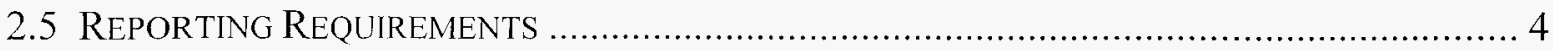

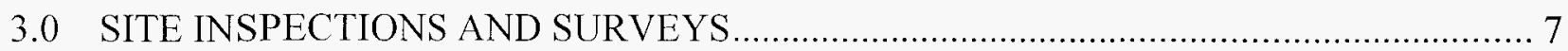

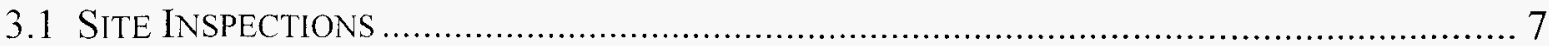

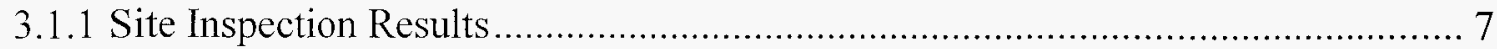

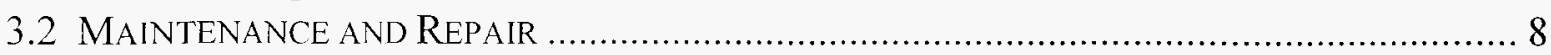

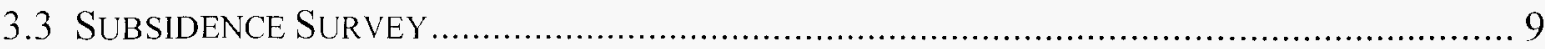

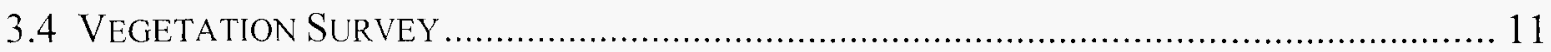

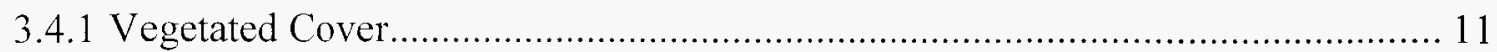

3.4.2 Conclusions and Recommendations ........................................................... 11

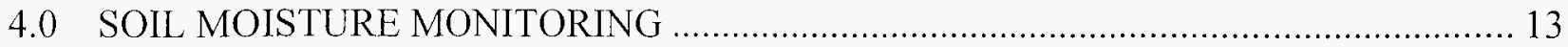

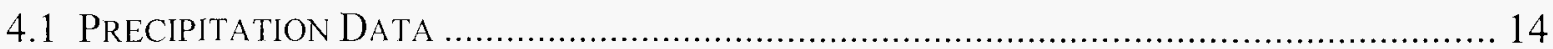

4.2 Soll Moisture Monitoring Results ……………....................................... 14

4.2.1 Discussion of Analytical Data Trends .......................................................... 14

5.0 SUMMARY, CONCLUSIONS, AND RECOMMENDATIONS .................................... 21

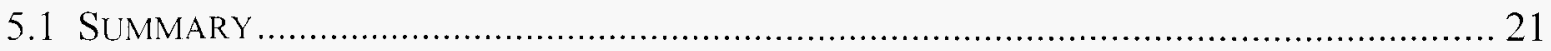

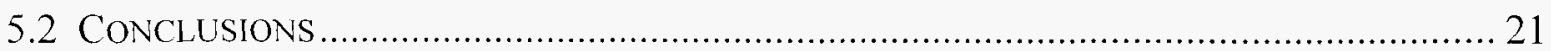

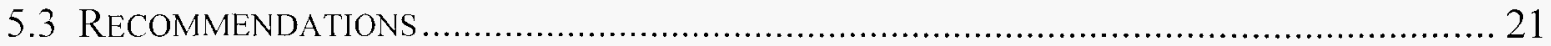

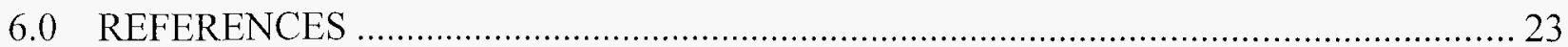




\section{TABLE OF CONTENTS (continued)}

\section{FIGURES}

Figure 1. Location OF CAU 110: AREA 3 WMD U-3AX/BL CRATER ..................................... 2

Figure 2. Plan View Of CAU 110, U-3ax/Bl Cover Time Domain Reflectometry Nest and

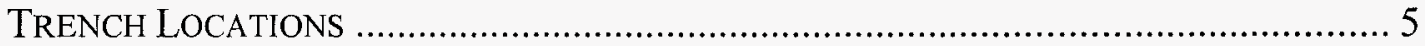

Figure 3. Time Domain ReFlectometry InStallation Diagram...................................... 6

Figure 4. Precipitation Data for Meteorological Station Buster Jangle Y ............... 15

FIGURE 5. EAST TDR NEST A SOIL MOISTURE CONTENT ....................................................... 16

FIgURE 6. EAST TDR NEST B SOIL MOISTURE CONTENT …................................................. 17

Figure 7. WEST TDR NEST A SoIL MOISTURE CONTENT .................................................. 18

Figure 8. West TDR Nest B Soil Moisture Content .................................................. 19

\section{TABLES}

Table 1. U-3ax/Bl Subsidence Monument Elevations and Subsidence Results ............ 10

Table 2. CAU 110 Average Percent Cover Estimates.................................................. 11

\section{APPENDICES}

Appendix A. Inspection Checklists, Field Notes, And Photographs

ApPendix B. Subsidence Monument Location Plat

ApPendix C. Vegetation Monitoring RePort - Spring 2005

APPENDIX D. PRECIPITATION RECORDS

LIBRARY DISTRIBUTION LIST 


\section{ACRONYMS AND ABBREVIATIONS}

\begin{tabular}{|c|c|}
\hline BJY & Buster Jangle Y \\
\hline $\mathrm{CAU}$ & Corrective Action Unit \\
\hline $\mathrm{cm}$ & centimeter(s) \\
\hline CFR & Code of Federal Regulations \\
\hline DOE & U.S. Department of Energy \\
\hline $\mathrm{DOE} / \mathrm{NV}$ & U.S. Department of Energy, Nevada Operations Office \\
\hline EPA & U.S. Environmental Protection Agency \\
\hline FFACO & Federal Facility Agreement and Consent Order \\
\hline $\mathrm{ft}$ & foot (feet) \\
\hline in & $\operatorname{inch}(\mathrm{es})$ \\
\hline $\mathrm{m}$ & meter(s) \\
\hline $\mathrm{m}^{2}$ & square meter(s) \\
\hline NDEP & Nevada Division of Environmental Protection \\
\hline NNSA/NV & U.S. Department of Energy, National Nuclear Security Administration \\
\hline \multirow{3}{*}{ NNSA/NSO } & Nevada Operations Office \\
\hline & U.S. Department of Energy, National Nuclear Security Administration \\
\hline & Nevada Site Office \\
\hline NTS & Nevada Test Site \\
\hline RCRA & Resource Conservation and Recovery Act \\
\hline RWMS & Radioactive Waste Management Site \\
\hline SM & subsidence monument(s) \\
\hline TDR & Time Domain Reflectometry \\
\hline VMC & Volumetric Moisture Content \\
\hline WMD & Waste Management Division \\
\hline
\end{tabular}


Post-Closure Report - CAU 110

Revision: 0

Date: August 2005

\section{THIS PAGE INTENTIONALLY LEFT BLANK}




\section{EXECUTIVE SUMMARY}

This Post-Closure Inspection and Monitoring report provides the results of inspections and monitoring for Corrective Action Unit (CAU) 110, Area 3 Waste Management Division (WMD) $\mathrm{U}-3 \mathrm{ax} / \mathrm{bl}$ Crater. This report includes an analysis and summary of the site inspections, repairs and maintenance, meteorological information, and soil moisture monitoring data obtained at CAU 110, for the annual period July 2004 through June 2005.

Site inspections of the cover were performed quarterly to identify any significant changes to the site requiring action. The overall condition of the cover, cover vegetation, perimeter fence, and use restriction warning signs was good. Settling was observed that exceeded the action level as specified in Section VII.B.7 of the Hazardous Waste Permit Number NEV HW009 (Nevada Division of Environmental Protection, 2000). This permit states that cracks or settling greater than 15 centimeters $(\mathrm{cm})$ ( 6 inches [in]) deep that extend 1.0 meter $(\mathrm{m})(3$ feet $[\mathrm{ft}])$ or more on the cover will be evaluated and repaired within 60 days of detection.

An area of settling along the east edge of the cover that was repaired previously in August 2003, December 2003, and May 2004 was observed during the September 2004 inspection to again be above the action level and required repair. This area and another area along the southeast edge of the cover that was first observed during the March 2004 inspection were repaired in October 2004. New cracks around these areas were observed during the June 2005 inspection, but were below the action level. These areas will be monitored closely for additional settling.

The semiannual subsidence surveys were done in September 2004 and March 2005. No significant subsidence was observed in the survey data. Monument 5 shows the greatest amount of subsidence $(-0.015 \mathrm{~m}[-0.05 \mathrm{ft}]$ compared to the baseline survey of 2000$)$. This amount is negligible and near the resolution of the survey instruments, and it does not indicate that subsidence is occurring on the cover.

Soil moisture results obtained to date indicate that the CAU 110 cover is performing as expected. At shallow depths, Time Domain Reflectometry (TDR) data indicated a significant increase in soil moisture due to heavier than normal precipitation, drying to less than 10 percent Volumetric Moisture Content (VMC) by the end of June. At $2.4 \mathrm{~m}(8 \mathrm{ft})$ below the cover surface, TDR data show a soil moisture content between 10 and 15 percent VMC. The wetting front on the West TDR Nest A has caused a loss of signal due to the high soil moisture content (greater than 30 percent VMC) in conductive soil. It is expected that data for this probe will recover as evapotranspiration causes the moisture content to decrease and the probe returns to its normal operating range.

During this reporting period, the cover has been subjected to above average precipitation and is currently reaching equilibrium from these events. It is expected that by the end of the next reporting period the soil moisture compliance level can be established. 
Post-Closure Report - CAU 110

Revision: 0

Date: August 2005

\section{THIS PAGE INTENTIONALLY LEFT BLANK}




\subsection{INTRODUCTION}

\subsection{SCOPE AND OBJECTIVES}

Corrective Action Unit (CAU) 110, Area 3 Waste Management Division (WMD) U-3ax/bl Crater, is located in Area 3 of the Nevada Test Site (NTS) in Nye County, Nevada. This report provides an analysis and summary of site inspections, repair and maintenance activities, subsidence surveys, vegetation monitoring, meteorological information, and soil moisture monitoring data obtained at CAU 110 for the period July 2004 through June 2005. This report has been prepared in accordance with the Federal Facility Agreement and Consent Order (FFACO) of 1996.

Inspections of CAU 110 are conducted quarterly to determine and document the physical condition of the U-3 ax/bl Crater cover and any unusual conditions that could impact the proper operation of the waste unit cover.

The objective of the soil moisture monitoring program is to monitor the stability of soil moisture conditions within the upper 2.4 meters $(\mathrm{m})(8$ feet [ft]) of the cover and detect changes that may indicate moisture movement exceeding the cover's designed performance expectations.

\subsection{BACKGROUND}

The U-3ax/bl Crater is a historic radioactive disposal unit located within the Area 3 Radioactive Waste Management Site (RWMS) on the NTS (Figure 1). The unit, which was formed by excavating the area between two subsidence craters (U-3ax and U-3bl), was operationally closed in 1987 under the Resource Conservation and Recovery Act (RCRA) as a hazardous waste landfill.

The U-3ax/bl Crater was identified as a historic RCRA site and was closed in accordance with the RCRA Part B Permit issued by the Nevada Division of Environmental Protection (NDEP), Permit Number NEV HW009 (NDEP, 2000). This permit specified that the unit would be closed under Title 40 Code of Federal Regulations (CFR) Part 265 (U.S. Environmental Protection Agency [EPA], 1996) closure requirements for interim status facilities. Additional closure requirements included U.S. Department of Energy (DOE) Order 5820.2A (DOE, 1988) and DOE Order 435.1 (DOE, 1999).

\subsection{GeOlogic SetTing}

Area 3 is located in Yucca Flat, within the northeast quadrant of the NTS. The Yucca Flat watershed is a structurally closed basin encompassing an area of approximately 780 square kilometers ( 300 square miles). The structural geomorphology of Yucca Flat is typical of the Basin and Range Physiographic Province. Yucca Flat lies in one of the most arid regions of the country. Water balance calculations for Area 3 indicate that it is continuously in a state of moisture deficit. 


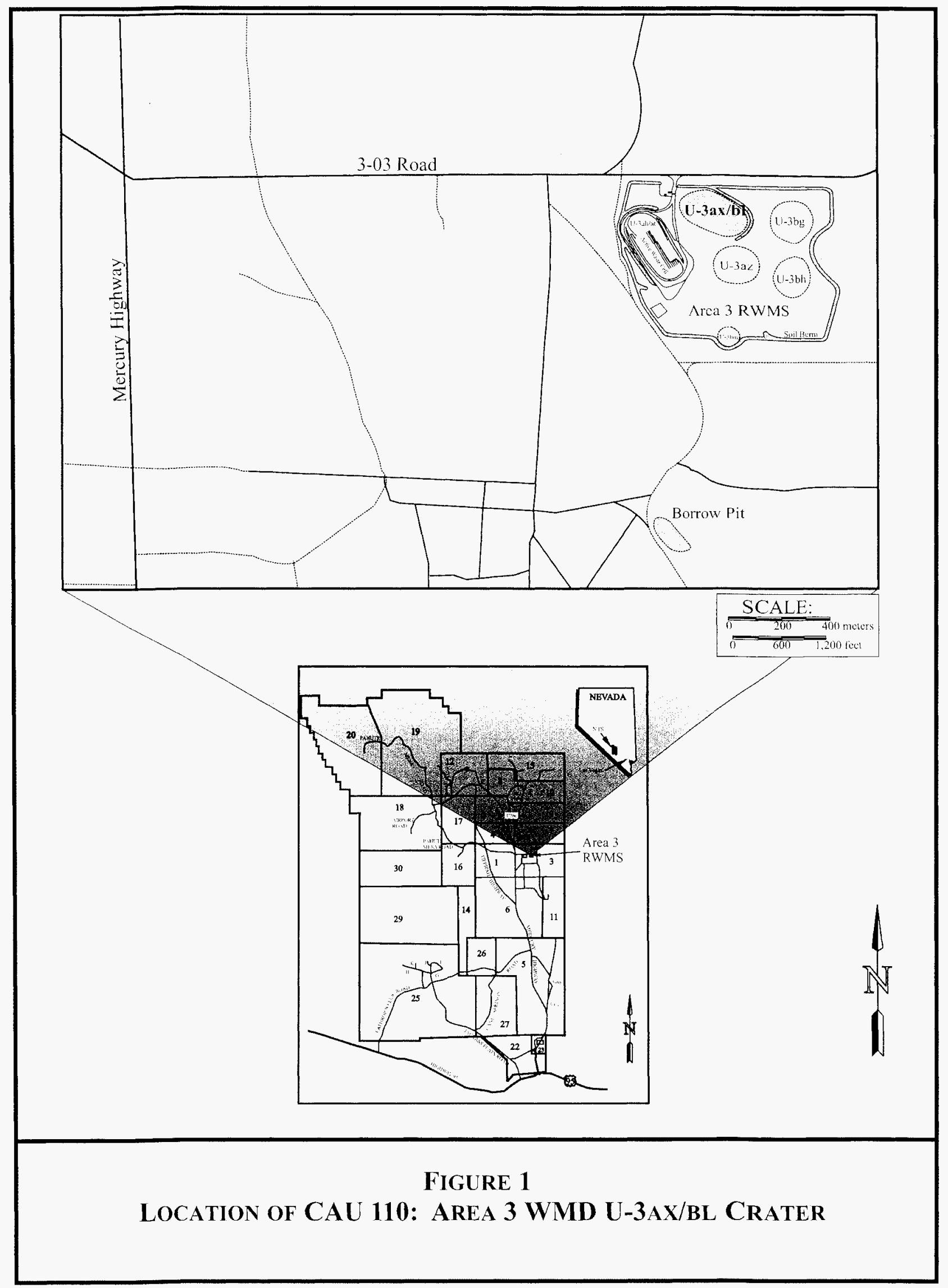




\subsection{POST-CLOSURE MONITORING REQUIREMENTS}

\subsection{BACKGROUND}

Post-closure monitoring requirements for CAU 110 are described in Closure Report for Corrective Action Unit 110 (U.S. Department of Energy, National Nuclear Security Administration Nevada Operations Office [NNSA/NV], 2001).

\subsection{INSPECTIONS}

Inspections are done quarterly, and consist of visual observations to inspect the condition of the cover and to document the status of use restriction warning signs and site fencing. Each site inspection is documented on a site inspection form, and copies of these are included in Appendix A of this report.

The post-closure inspection consists of the following:

- The perimeter of the cover fencing is walked by the inspector, and the condition of the fencing, warning signs, entrance gate, and lock is documented.

- The seven survey subsidence markers located on the cover are inspected. In addition, the elevations of all seven survey markers are surveyed twice a year and compared to baseline elevations collected in 2000 to determine if the cover has subsided.

- During each inspection, any changes in the condition of the cover, warning signs, or fenced area are documented. Specific changes noted on the current condition of the cover include, but are not limited to, trash/debris within the fenced compound, animal burrows/nesting activity, or erosion of the cover.

- Cracks or areas of settling less than 15 centimeters $(\mathrm{cm})(6$ inches [in]) deep on the cover are documented and scheduled for repair on an annual basis. Larger cracks or areas of settling are immediately evaluated and repaired within 60 days.

- All repair work will preserve the original cover "as built" design. If the cover repair requires modification of the cover design, U.S. Department of Energy, National Nuclear Security Administration Nevada Site Office (NNSA/NSO) will present a formal design modification request to the NDEP prior to making the design modification.

\subsection{COVER Monitoring}

The CAU 110 cover is designed to limit infiltration of precipitation into the disposal unit by evapotranspiration of vegetation on the cover. The cover performance is monitored using Time

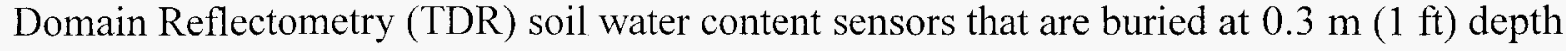
intervals up to $2.4 \mathrm{~m}$ ( $8 \mathrm{ft}$ ) within the waste cover to provide water content profile data. TDR probes are installed at a distance of $50.3 \mathrm{~m}(165 \mathrm{ft})$ from the southern edge of the cover. A profile of eight probes (a stack) is repeated at four locations across the cover (Figures 2 and 3 ). The soil water content profile data are used to determine whether the cover is functioning as designed. Soil moisture content data from the TDR moisture probes are recorded daily and stored on a datalogger. The data are downloaded remotely over a radio/telephone link. 


\subsection{Compliance Criteria}

The CAU 110 cover boundary is defined by the fence installed around the cover, which is approximately 3.0 hectares ( 7.5 acres). The point of compliance is at the deepest TDR soil

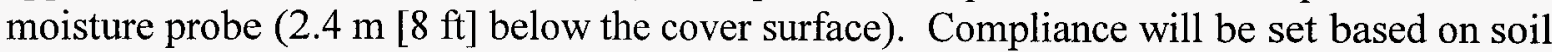
moisture content; however, the specific criteria will not be established until enough data have been collected during average site conditions to establish a realistic compliance level. Once the soil moisture content within the cover reaches equilibrium under normal or above average precipitation conditions, soil moisture compliance values will be agreed upon with the NDEP. During this monitoring period, the response of the cover under above average precipitation conditions was observed and compared to predicted performance. Once the cover reaches equilibrium, which is expected to occur during the next reporting period, a compliance level can be set.

The following compliance criteria have been established:

1. Notify the NDEP of noncompliance within 14 days of determining that the cover is not operating according to the established compliance criteria.

2. Compile a list of non-critical maintenance activities (cracks or settling imperfections equal to or less than $15 \mathrm{~cm}$ [6 in] deep on the cover) and address them in the following fiscal year.

3. Evaluate and repair cracks or settling features greater than $15 \mathrm{~cm}(6$ in) deep which extend $1 \mathrm{~m}(3 \mathrm{ft})$ or more on the cover within 60 days of detection.

\subsection{REPORTING REQUIREMENTS}

All inspection and maintenance activities conducted during the year will be documented and submitted to the NDEP. The annual post-closure inspection and monitoring report will be provided on or before August 31 of each year. The proposed duration of post-closure inspections is five years. After five years of post-closure inspections and monitoring, the NNSA/NSO may submit a request to the NDEP to reevaluate the monitoring program and/or schedule.

The annual post-closure report will include the following information:

- Brief summary of each inspection

- Inspection checklists, field notes, and site photographs

- Subsidence survey results

- Monthly precipitation records for the Buster Jangle Y (BJY) meteorological station

- Periodic reports on the health of cover vegetation

- Soil moisture content profiles for the reported monitoring period

- Maintenance and repair documentation (if any)

- Specific recommendations for nonstandard maintenance or changes in post-closure monitoring 
Post-Closure Report - CAU 110

Revision: 0

Date: August 2005

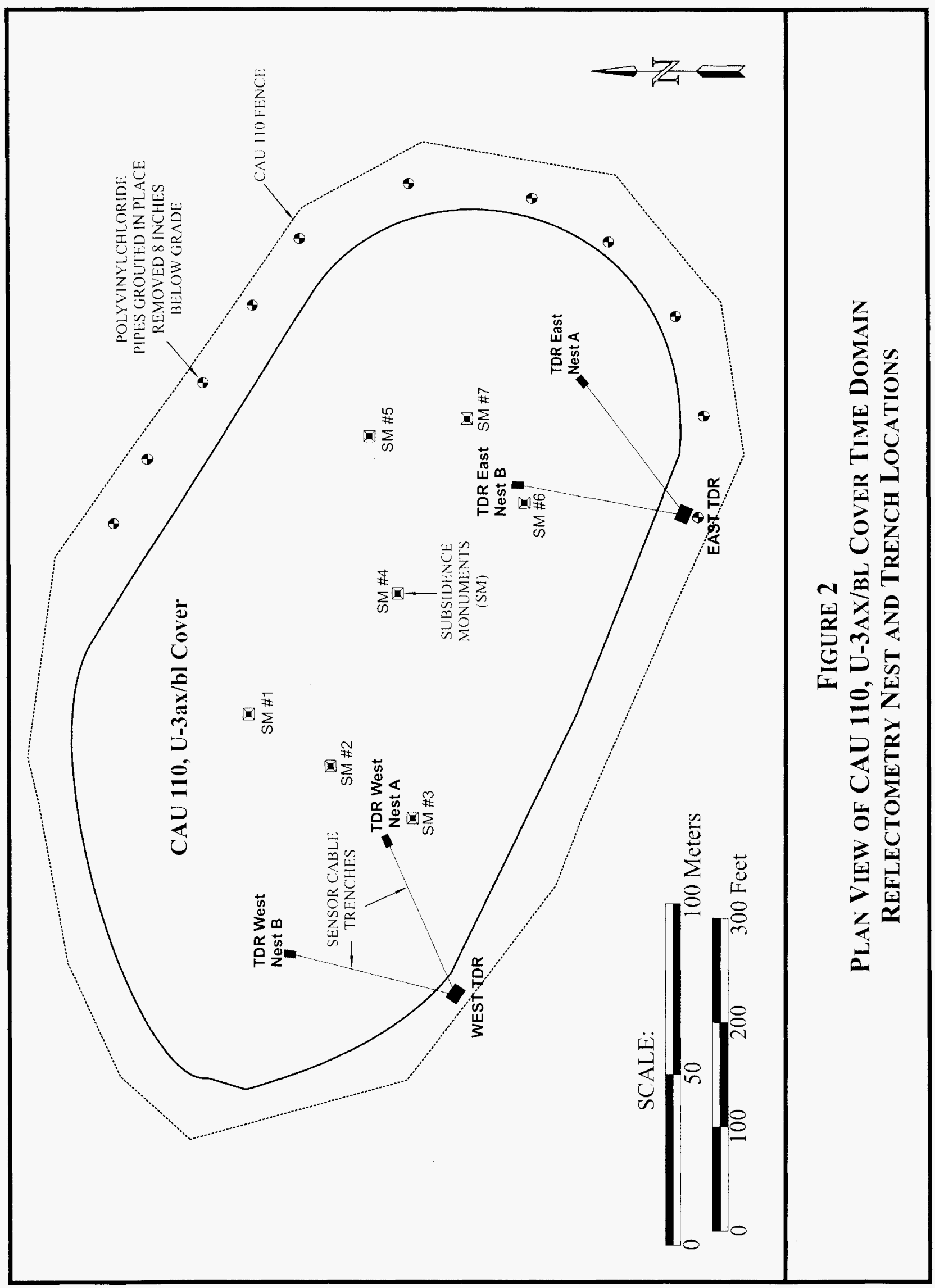




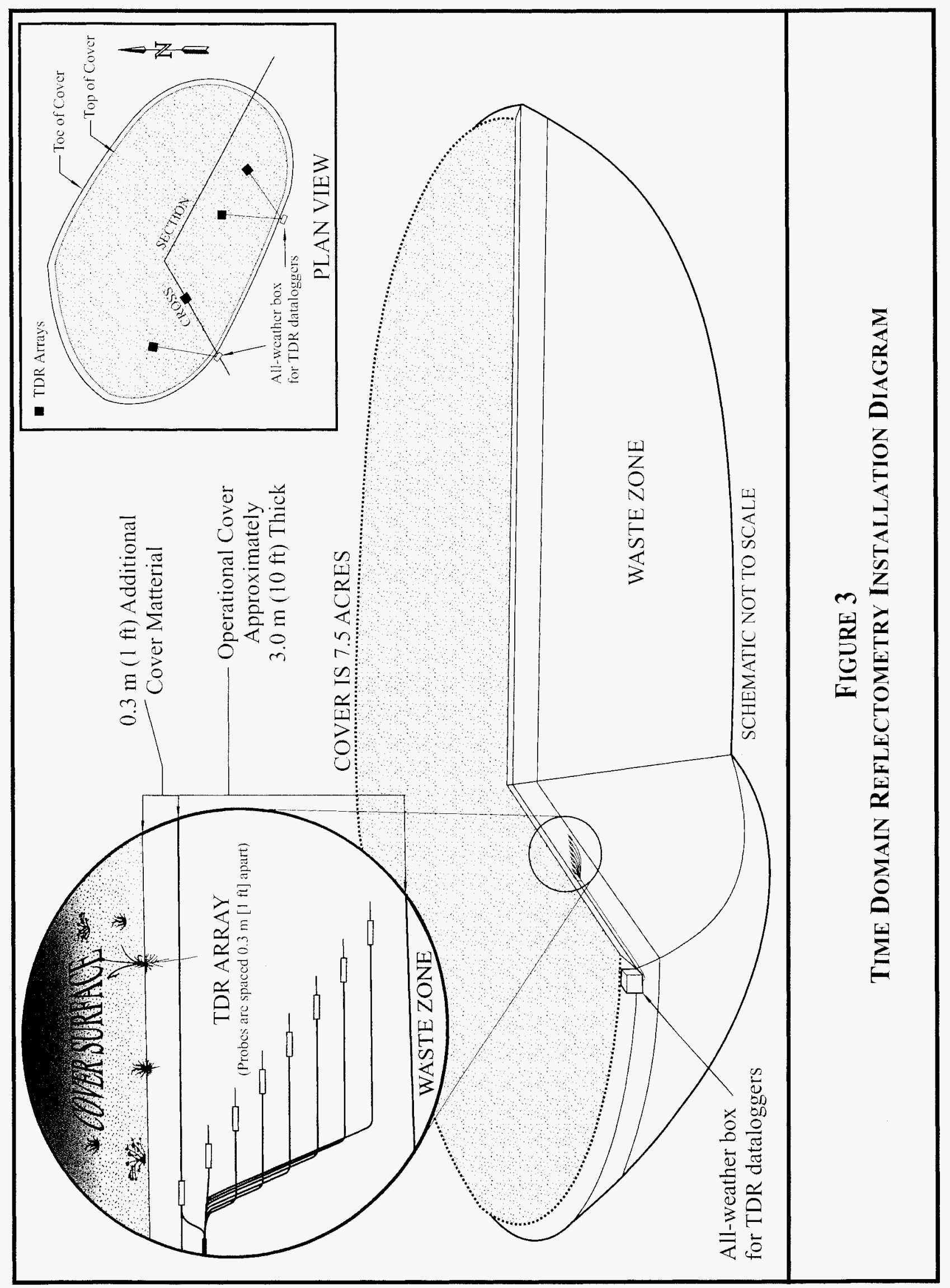




\subsection{SITE INSPECTIONS AND SURVEYS}

\subsection{SITE INSPECTIONS}

Site inspections are conducted in March, June, September, and December. The inspections are completed to evaluate and document the performance and maintenance needs of CAU 110 in accordance with the requirements of Title 40 CFR \$265.15, the RCRA Part B Permit (NDEP, 2000), and the CAU 110 Closure Report (NNSA/NV, 2001). Site inspection documentation includes copies of the inspection checklists, field logbook notes, and site photographs. Copies of the inspection checklists and associated field notes for September 2004, December 2004, March 2005, and June 2005, as well as site photographs, are included in Appendix A.

\subsubsection{Site Inspection Results}

September 14, 2004, Inspection

- Two areas of cracking and settling (one along the east side of the cover and one along the southeast side of the cover) were at actionable levels. The area along the east side of the cover had been repaired on three previous occasions.

- Animal burrows were noted on the cover.

- The condition of warning signs, fencing, subsidence monuments (SMs), and cover vegetation was good.

Conclusions/Recommendations:

- Continue inspections as scheduled.

- Repair the two areas of cracking and settling.

December 14, 2004, Inspection

- The two areas of cracking and settling were repaired on October 25, 2004, and were in good condition during this inspection, with no indication of further cracking or settling.

- Animal burrows were noted on the cover.

- The condition of warning signs, fencing, SMs, and cover vegetation was good.

Conclusions/Recommendations:

- Continue inspections as scheduled.

- Monitor repaired areas for evidence of further settling.

March 21, 2005, Inspection

- The previously repaired areas were in good condition with no indication of cracking or settling.

- Animal burrows were noted on the cover.

- The condition of warning signs, fencing, SMs, and cover vegetation was good. 
Conclusions/Recommendations:

- Continue inspections as scheduled.

- Trap and relocate small mammals in approximately April, June, and September of 2005.

- Monitor repaired areas for evidence of further settling.

June 21, 2005, Inspection

- Minor cracks were observed around the previously repaired areas, but they did not exceed the settling compliance criterion.

- Animal burrows were noted on the cover, but fewer were observed than during previous inspections.

- The condition of warning signs, fencing, SMs, and cover vegetation was good.

Conclusions/Recommendations:

- Continue inspections as scheduled.

- Perform an inspection in August 2005 to follow up and evaluate the cracking around the previously repaired areas and the possible need for repair.

\subsection{MAINTENANCE AND REPAIR}

Site maintenance and cover repairs were made in October 2004, April 2005, and June 2005 as a result of observations made during site inspections.

\section{October 25, 2004, Repairs}

During the September 14, 2004, inspection, two areas of settling (one along the east side of the cover and one along the southeast side of the cover) exceeded the settling compliance criterion. The area along the east side of the cover had been repaired on three previous occasions. The two areas were repaired on October 25, 2004. A portable, gas-powered tamper was used to collapse the cracks and open up the void spaces to the surface. The areas were then backfilled with clean soil using wheelbarrows and shovels, and compacted using the tamper. During the repair, a third system of cracks was noticed near the area along the southeast side of the cover. This area was also repaired during this time. Field notes for this repair are included in Appendix A.

April 17, 2005, Power Failure of West TDR

On January 3, 2005, a connection from the solar panel to the battery failed, allowing the storage battery to completely discharge and resulting in the data logger failing to collect data on the West TDR nests from January 3 through April 16, 2005. The problem was identified on April 16, repaired on April 17,2005, and the battery replaced on April 21, 2005. The East TDR nests were unaffected. 


\section{April 19-21, 2005, Mammal Trapping}

During the March 21, 2005, site inspection, it was recommended to trap and relocate small mammals on the cover during three sessions in 2005 . This activity was first performed on April 19-21, 2005. A total of 130 deer mice, kangaroo rats, and other small mammals were trapped and relocated from the cover.

\section{June 14-16, 2005, Mammal Trapping}

The second session of mammal trapping was performed on June 14-16, 2005. During this second round of trapping, 26 small mammals were trapped and relocated from the cover. The third session of mammal trapping is planned for September or October of 2005.

\section{June 30, 2005, TDR Calibration}

On June 30, 2005, an inspection of the TDR system and calibration were performed to determine if a partial loss of signal at the 1.5-m (5-ft) depth was due to a calibration shift of the TDR waveform, or if it was due to signal loss due to high conductivity of the soils from increased soil moisture content. The individual TDR waveforms were examined and found to be correctly registered for each multiplexer setting and showed no shift in position. The TDR instrumentation was found to be operating within its specifications, and the loss of signal was attributed to high soil moisture levels outside the calibration range of the TDR probes.

The general increase in soil moisture content that occurred after April 2002 at the East TDR Nest B noted in the previous report was not the result of an instrumentation problem but is due to the soil in that nest reaching equilibrium.

\subsection{SUBSIDENCE SURVEY}

Seven SMs were installed on the cover to provide elevation control and to determine if subsidence of the cover occurs. The SM location map is provided in Appendix B. The initial baseline subsidence survey was done on December 14,2000. Subsequent surveys are done twice a year and are compared to the December 2000 baseline survey results. During this monitoring period, the subsidence surveys were done on September 9, 2004, and March 14, 2005.

The subsidence survey results are tabulated in Table 1. No significant subsidence is observed in the survey data. Monument 5 shows the greatest decrease in elevation $(-0.015 \mathrm{~m}[-0.05 \mathrm{ft}])$ compared to the baseline survey in 2000. Calculated subsidence values are negligible and near the resolution of the survey instruments, and do not indicate that subsidence is occurring on the cover. 
Table 1. U-3ax/bl Subsidence Monument Elevations and Subsidence Results

\begin{tabular}{|c|c|c|c|c|c|c|c|}
\hline \multirow{2}{*}{ DATE } & \multicolumn{7}{|c|}{$\frac{\text { Elevation at Top of Monument }}{\text { Subsidence (ft) }}$} \\
\hline & SM \#1 & $\mathrm{SM} \# 2$ & SM \#3 & SM \#4 & SM \#5 & SM \#6 & SM \#7 \\
\hline \multirow{2}{*}{$\begin{array}{l}\text { December } 2000 \\
\text { Baseline }\end{array}$} & $4,021.84$ & $4,021.28$ & $4,019.83$ & $4,020.99$ & $4,021.87$ & $4,019.25$ & $4,020.52$ \\
\hline & - & - & - & - & - & - & - \\
\hline \multirow{2}{*}{ July 2001} & $4,021.83$ & $4,021.28$ & $4,019.83$ & $4,020.98$ & $4,021.86$ & $4,019.24$ & $4,020.51$ \\
\hline & -0.01 & 0.00 & 0.00 & -0.01 & -0.01 & -0.01 & -0.01 \\
\hline \multirow{2}{*}{ January 2002} & $4,021.84$ & $4,021.28$ & $4,019.83$ & $4,020.98$ & $4,021.86$ & $4,019.24$ & $4,020.51$ \\
\hline & 0.00 & 0.00 & 0.00 & -0.01 & -0.01 & -0.01 & -0.01 \\
\hline \multirow{2}{*}{ September 2002} & $4,021.83$ & $4,021.27$ & $4,019.83$ & $4,020.98$ & $4,021.86$ & $4,019.24$ & $4,020.50$ \\
\hline & -0.01 & -0.01 & 0.00 & -0.01 & -0.01 & -0.01 & -0.02 \\
\hline \multirow{2}{*}{ January 2003} & $4,021.83$ & $4,021.27$ & $4,019.83$ & $4,020.98$ & $4,021.86$ & $4,019.24$ & $4,020.50$ \\
\hline & -0.01 & -0.01 & 0.00 & -0.01 & -0.01 & -0.01 & -0.02 \\
\hline \multirow{2}{*}{ July 2003} & $4,021.83$ & $4,021.27$ & $4,019.83$ & $4,020.97$ & $4,021.85$ & $4,019.24$ & $4,020.50$ \\
\hline & -0.01 & -0.01 & 0.00 & -0.02 & -0.02 & -0.01 & -0.02 \\
\hline \multirow{2}{*}{ March 2004} & $4,021.82$ & $4,021.26$ & $4,019.82$ & $4,020.97$ & $4,021.83$ & $4,019.22$ & $4,020.49$ \\
\hline & -0.02 & -0.02 & -0.01 & -0.02 & -0.04 & -0.03 & -0.03 \\
\hline \multirow{2}{*}{ September 2004} & $4,021.82$ & $4,021.26$ & $4,019.82$ & $4,020.96$ & $4,021.83$ & $4,019.23$ & $4,020.49$ \\
\hline & -0.02 & -0.02 & -0.01 & -0.03 & -0.04 & -0.02 & -0.03 \\
\hline \multirow{2}{*}{ March 2005} & $4,021.82$ & 4.021 .26 & $4,019.82$ & $4,020.96$ & $4,021.82$ & 4.019 .22 & $4,020.49$ \\
\hline & -0.02 & -0.02 & -0.01 & -0.03 & -0.05 & -0.03 & -0.03 \\
\hline
\end{tabular}

Elevations based on North American Vertical Datum of 1929 in feet. 


\subsection{VEGETATION SURVEY}

The CAU 110 cover was initially planted with native seed on December 4 through 5, 2000 . Revegetation surveys have been conducted every spring since the site was seeded to assess the success of the seeding effort. The May 2005 vegetation survey report and methodology are included in Appendix C. The status of the vegetation on the CAU 110 cover was evaluated by estimating the amount of vegetative cover and density of plant species.

\subsubsection{Vegetated Cover}

\section{$\underline{\text { Plant Cover }}$}

Plant cover was 75 percent higher this year than it was last year. Perennial plant cover continues to increase on the closure cover. Annual plant cover was not significantly different than 2004 . In 2004, about 25 percent of total plant cover was from annuals. In 2005, a year of above normal precipitation, annuals only make up 17 percent of the total cover. Total plant cover on the edges of the closure cover, which has re-seeded naturally, was 23 percent, slightly higher than on the closure cover. A major difference is that all of the plant cover on the un-seeded edges is from annual plants. The average percent cover estimates over the last five years are presented in Table 2.

Table 2. CAU 110 average Percent Cover Estimates

\begin{tabular}{|c|c|c|c|c|c||}
\hline \hline & $\begin{array}{c}\mathbf{2 0 0 1} \\
\text { (percent) }\end{array}$ & $\begin{array}{c}\mathbf{2 0 0 2} \\
\text { (percent) }\end{array}$ & $\begin{array}{c}\mathbf{2 0 0 3} \\
\text { (percent) }\end{array}$ & $\begin{array}{c}\mathbf{2 0 0 4} \\
\text { (percent) }\end{array}$ & $\begin{array}{c}\mathbf{2 0 0 5} \\
\text { (percent) }\end{array}$ \\
\hline \hline Total Vegetative Cover & 7.8 & 6.4 & 3.2 & 12.8 & 20.2 \\
\hline Perennial Cover & 2.6 & 6.4 & 2.4 & 9.6 & 16.8 \\
\hline Annual Cover & 5.2 & 0.0 & 0.8 & 3.2 & 3.4 \\
\hline \hline Mulch/Litter & 43.6 & 24.1 & 28.0 & 14.6 & 26.2 \\
\hline Bare & Not Recorded & Not Recorded & 30.4 & 38.4 & 5.4 \\
\hline Rock & Not Recorded & Not Recorded & 38.4 & 34.2 & 48.2 \\
\hline
\end{tabular}

\section{$\underline{\text { Plant density }}$}

In 2005, annual plant density was the highest since the cover was seeded. The 100 plants per square meter this year represents a 20 percent increase over last year and a five-fold increase over annual density estimates for 2003 . The species with the most significant increases were buckwheat, halogeton, and cheatgrass. Interestingly, the density of Russian thistle was slightly lower this year than last year. As was common throughout much of the region this spring, there was an abundance of native annual forbs. Common native wildflowers observed on the cover this year include smooth desertdandelion, dustymaiden, blazingstar, Nevada cateye, bristly fiddleneck, and tall tumblemustard.

\subsubsection{Conclusions and Recommendations}

Total plant cover increased from 12.8 percent in 2004 to 20.2 percent in 2005 . This is a good indication that native plant species on the cover have successfully survived the drought 
conditions that followed reseeding in 2000 . The almost 8 percent increase in plant cover this year is attributed to increases in perennial plant cover. Perennial plant cover is 17 percent this year, a significant increase over the 2 percent just two years ago. In contrast, there was only a slight ( 0.2 percent) increase in annual plant cover from 2004 to 2005.

Based on revegetation efforts in similar regions, a goal of 12 percent plant cover after five years was established. This does not represent the final plant cover expected on the cover, but an intermediate stage. The five-year goal was met and exceeded this year. Actual total plant cover is 20 percent, and the majority (17 percent) is attributed to perennial native plants. Eventually, plant cover should approach 25 percent based on the results of cover estimates for similar plant communities on the NTS.

The plant community on the cover is well established. The density of perennial plant species has remained the same over the last three years. Plant cover has increased to over 20 percent, well above the goal of 12 percent. There is no indication that remedial revegetation is necessary. Vegetation monitoring in future years should focus on annual weedy species, specifically halogeton, cheatgrass, and Russian thistle. If these species increase in density and cover, and appear to have a detrimental effect on the perennial plant species, as evidenced by decreases in perennial plant cover and/or density, some remedial action may be necessary to protect the composition and stability of the vegetative cover.

The CAU 110 cover vegetation should continue to be monitored annually to evaluate plant cover, density, and diversity. 


\subsection{SOIL MOISTURE MONITORING}

The CAU 110 cover is designed to limit infiltration into the disposal unit by use of evapotranspiration from vegetation that was established on the cover for that purpose. The cover performance is monitored using TDR to provide a profile of the water content within the cover. The soil water content data will establish whether the cover is performing as designed and is in compliance with the closure plan and any compliance criteria established in the future. The point

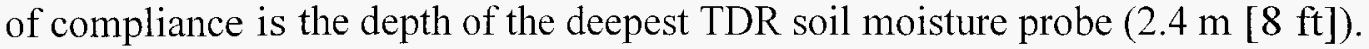

Compliance will be based on soil moisture content; however, the area was under drought conditions since monitoring began in 2001 and through most of 2004 . The total annual precipitation (January 2004 through December 2004) was $26.49 \mathrm{~cm}(10.43 \mathrm{in})$. A total of $11.2 \mathrm{~cm}$ (4.4 in) of that was received between October and December of 2004. During the first four months of $2005,12.7 \mathrm{~cm}$ (5.0 in) were received. The site experienced nearly twice the normal precipitation for the current monitoring period. The above average precipitation noted during this reporting period will allow the monitoring of a wetting front to be observed and compared to predicted cover performance. The observed system response under above-average conditions will allow the setting of the compliance level once the cover reaches equilibrium, which is expected to occur during the next reporting period.

The soil moisture content is obtained using two Campbell Scientific TDR-100 dataloggers housed in instrumentation shelters located along the periphery of the cover (Figure 2). TDR probes are Campbell Scientific CS610s using RG8 coaxial cable. The probes are installed at a

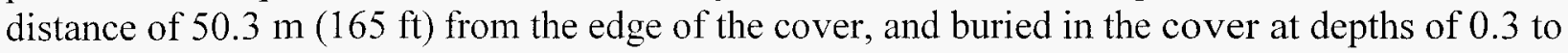
$2.4 \mathrm{~m}(1 \mathrm{to} 8 \mathrm{ft}$ ) below the cover surface, one probe every $0.3 \mathrm{~m}(1 \mathrm{ft})$. Profiles of eight probes (a nest) are present at four locations across the cover (Figure 3). Soil moisture content data from the TDR moisture probes are collected once per day and stored on a datalogger. A radio link connects both the eastern and western TDR dataloggers to a telephone line at the Area 3 RWMS office, and the data are downloaded over this remote link.

Calibration of the TDR probes was documented in Appendix I of the CAU 110 Closure Report (NNSA/NV, 2001). The TDR probes were calibrated with a "dry-down" method using native soils and the full cable length. The results of the calibration indicated that a site-specific calibration equation should be used instead of the standard Topp equation. It was also noted that due to the long cable lengths and high soil conductivities, the TDR reflection end points were extremely flat under saturated and near-saturated conditions, resulting in unreliable data in these regions. Therefore, the TDR calibration was fit only up to 30 percent Volumetric Moisture Content (VMC).

A linear regression of the calibration data over the range of 5 to 30 percent VMC yielded the following calibration equation:

$$
\% \mathrm{VMC}=10.3737 \times(\mathrm{L} / \mathrm{L})-17.137
$$

Where $\mathrm{L} / \mathrm{L}$ is the trace length/probe length as recorded by the datalogger. 


\subsection{Precipitation Data}

Precipitation data were collected from the Air Resources Laboratory, Special Operations and Resource Division's CLINET Station BJY, located at 37E 03' 46" N, 116E 03' 09" W, in Area 3 of the NTS, approximately 4.8 kilometers ( 3 miles) northwest of CAU 110 . Precipitation records obtained from this station are used to report the official rainfall for CAU 110 closure. Precipitation records for this station for the period July 2004 through June 2005 are found in Appendix D. The precipitation data are presented in Figure 4.

The total annual precipitation (January 2004 through December 2004) was $26.49 \mathrm{~cm}$ (10.43 in), which is above average. The average annual precipitation over the period 1960 to 2004 at the BJY Station is $16.26 \mathrm{~cm}(6.40 \mathrm{in})$. The total precipitation recorded for the current monitoring period from July 2004 through June 2005 was $30.23 \mathrm{~cm}$ (11.90 in). The average rainfall for the same period from 1960 to the present is $16.51 \mathrm{~cm}$ (6.50 in), which indicates that the site experienced nearly twice the precipitation than normal for the current monitoring period.

\subsection{SOIL MOISTURe MONITORING RESUlts}

\subsubsection{Discussion of Analytical Data Trends}

Graphs of the TDR-derived soil moisture content, combined with the daily precipitation from the BJY meteorological station, are presented in Figures 5 through 8. Data collection began on January 25,2001 , just prior to the start of supplemental irrigation.

The soil moisture graphs, Figures 5 through 8 , show several responses: the initial conditions, the irrigation wetting event, infiltration, and the trend to steady-state conditions. The initial conditions at the beginning of the data collection reflect the disturbed soil's intrinsic moisture conditions. The installation of the TDR probes is described in detail in the CAU 110 Closure Report (NNSA/NV, 2001). Health and safety considerations required that hazards caused by dust be minimized during the TDR probe installation; the trenching and compaction of each of the soil lifts required some water to be added to the soils prior to handling. The amount of water added to the soil, while kept to a minimum, was variable and resulted in a vertical moisture content profile that is not necessarily monotonic with depth as would be expected with a natural profile. Consequently, some depths appear wetter than others and will remain so until the system fully equilibrates.

Summer temperatures and germination of the seeds, along with the increase in evapotranspiration have produced the long-term trends, which can be seen in the data from about October 2001 to the present. An annual cycle of increasing soil moisture content at all depths can be observed peaking in August and decreasing to a minimum in January. This seasonal cyclic behavior lags behind the temperature and is most likely a combination of effects caused by the increased thermal gradient, water vapor transport from depth, and the lack of transpiration of plants during the hot summer months. 


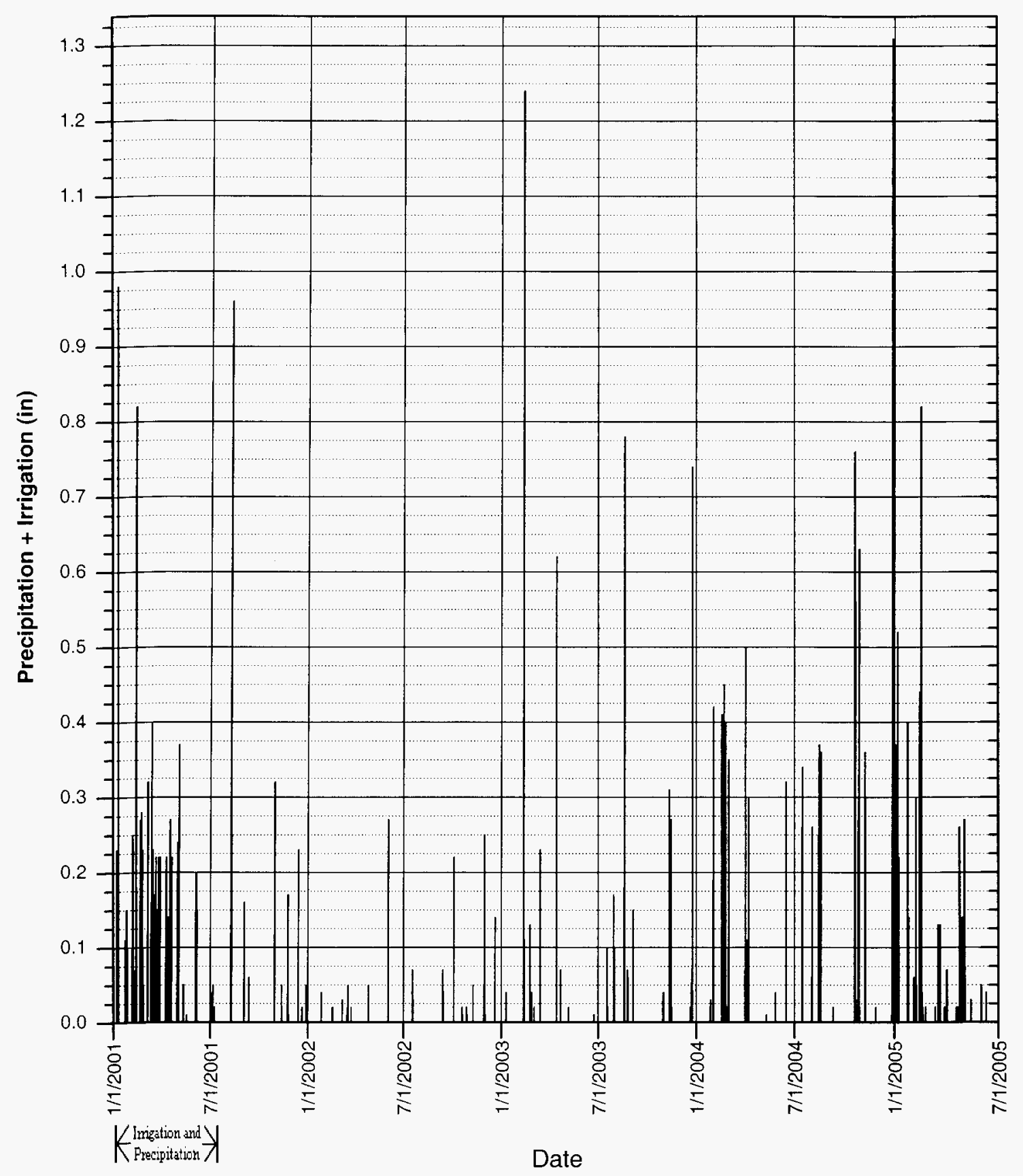

FIGURE 4

PRECIPITATION DATA FOR METEOROLOGICAL STATION BUSTER JANGLE Y 


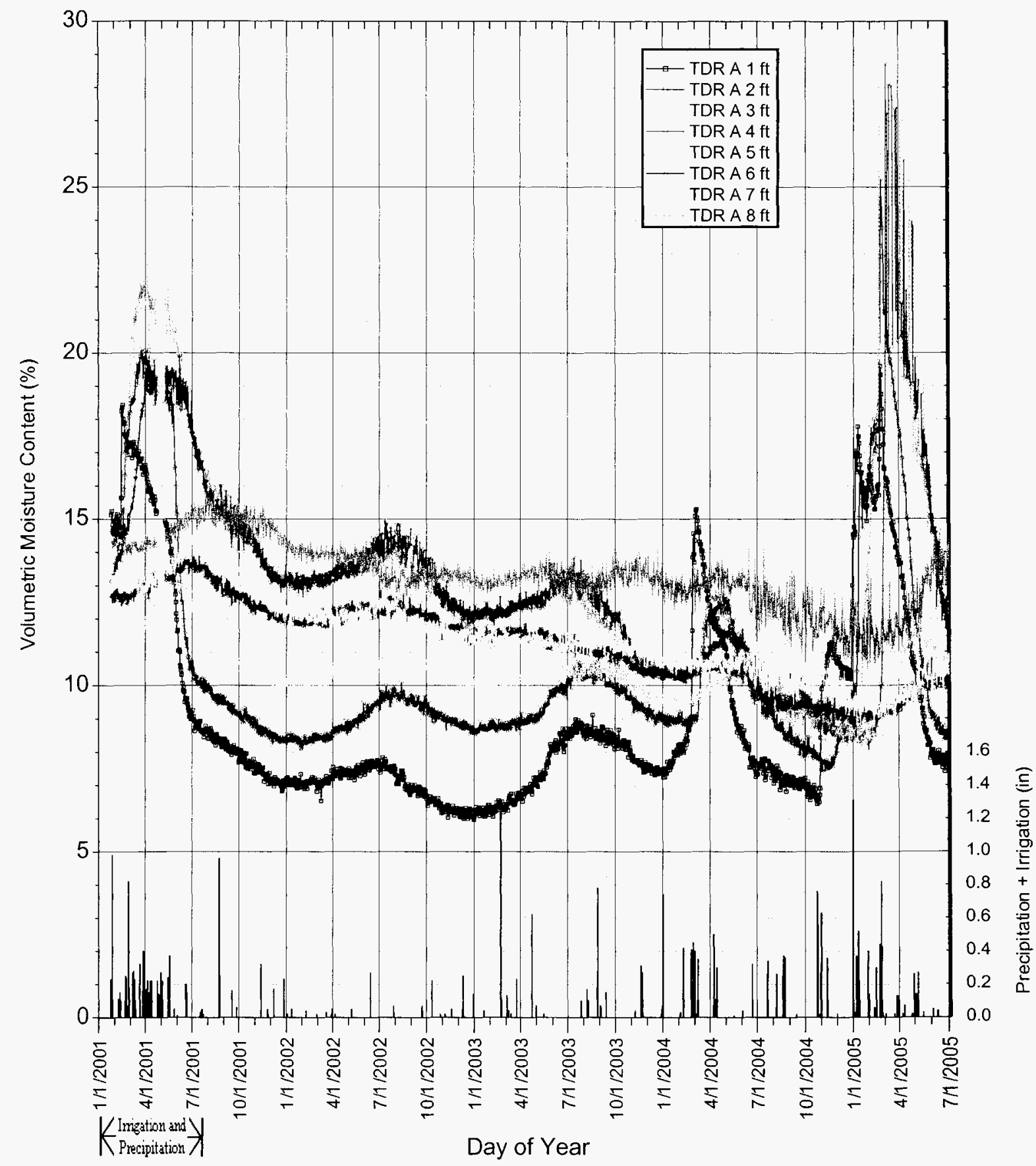

FIGURE 5

EAst TDR Nest A SOIL MOISTURe CONTENT 


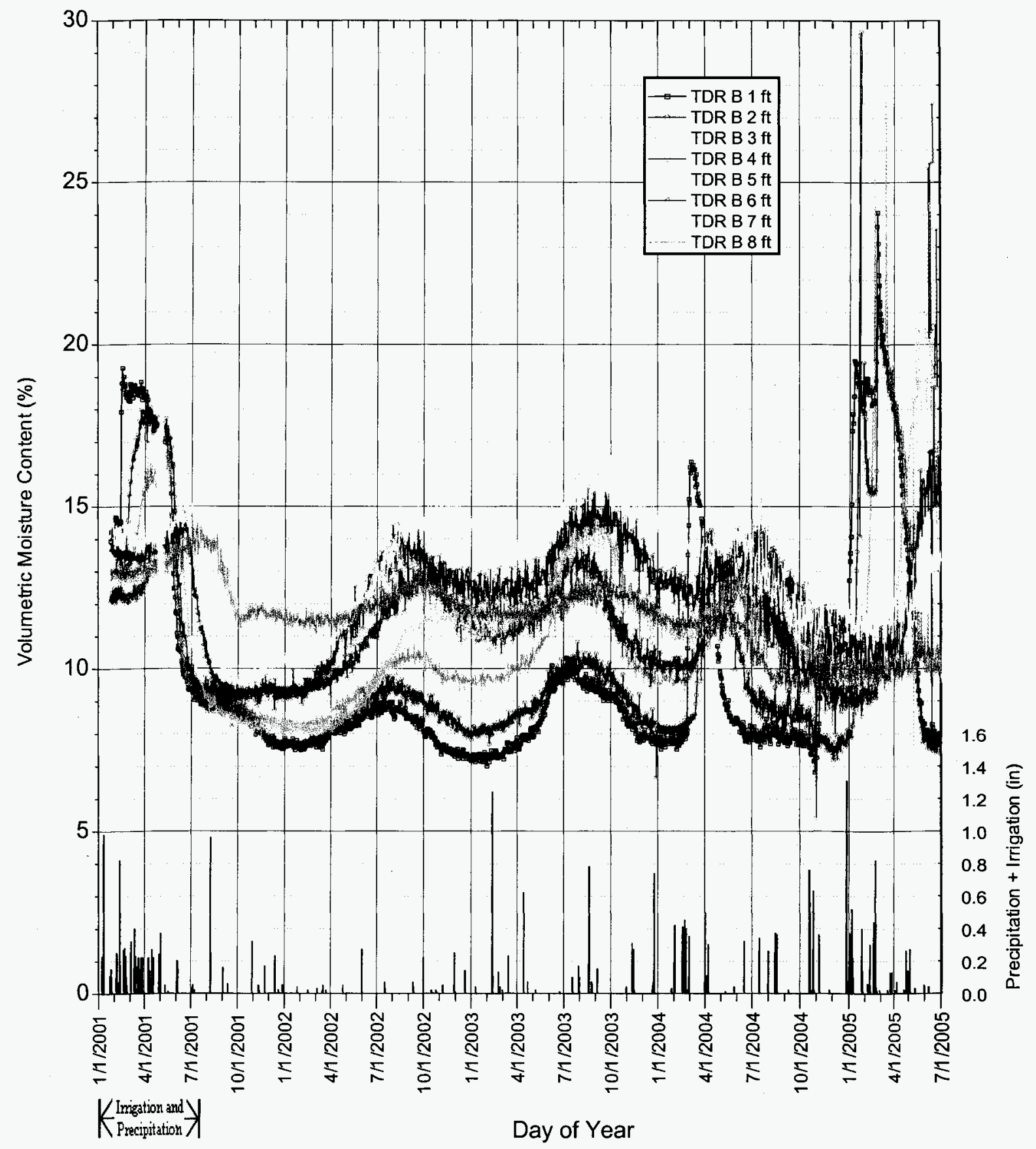

FiguRe 6

EAST TDR NEST B SOIL MOISTURE CONTENT 


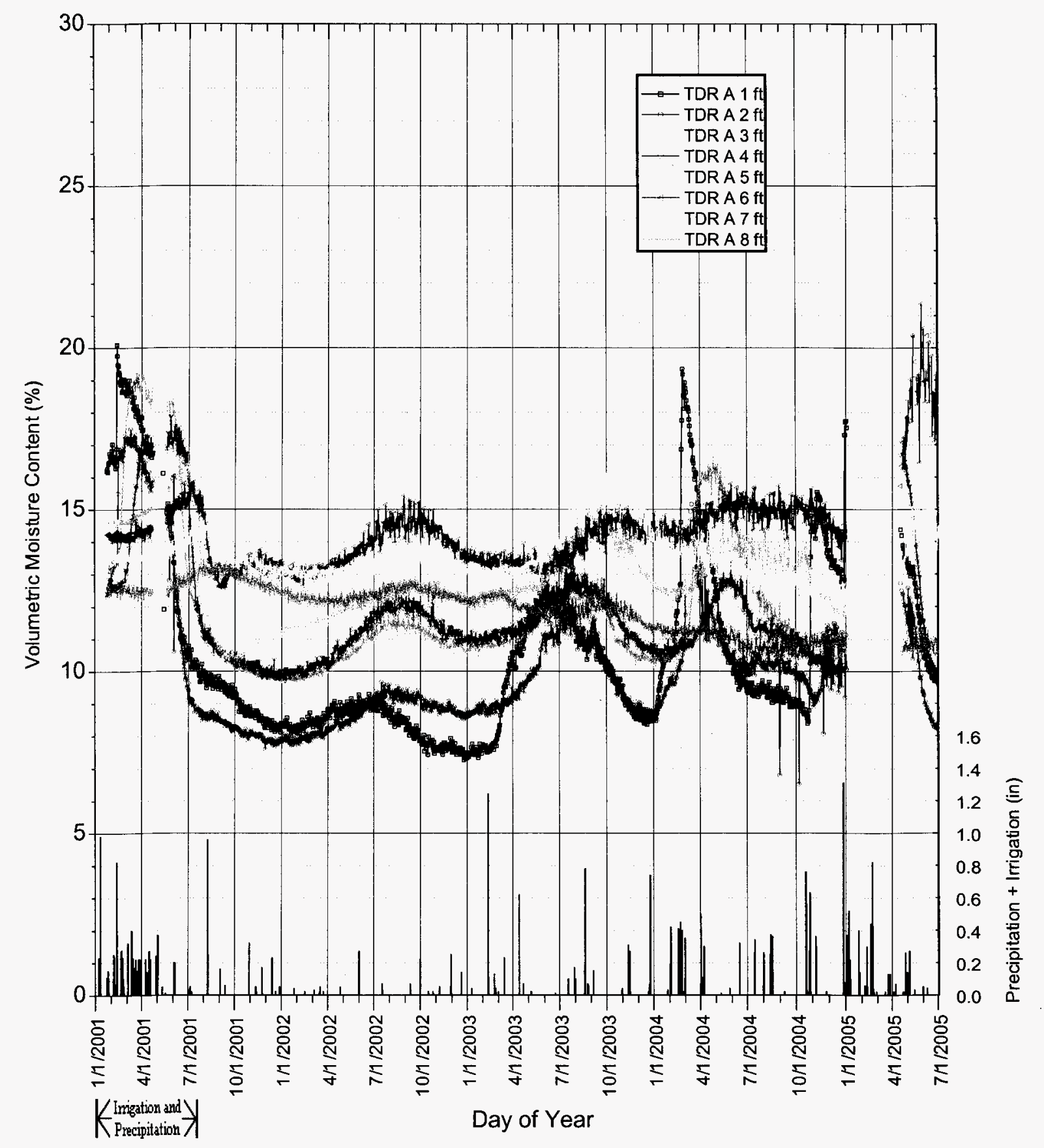

FIGURE 7

WEST TDR NEST A SOIL MOISTURE CONTENT 


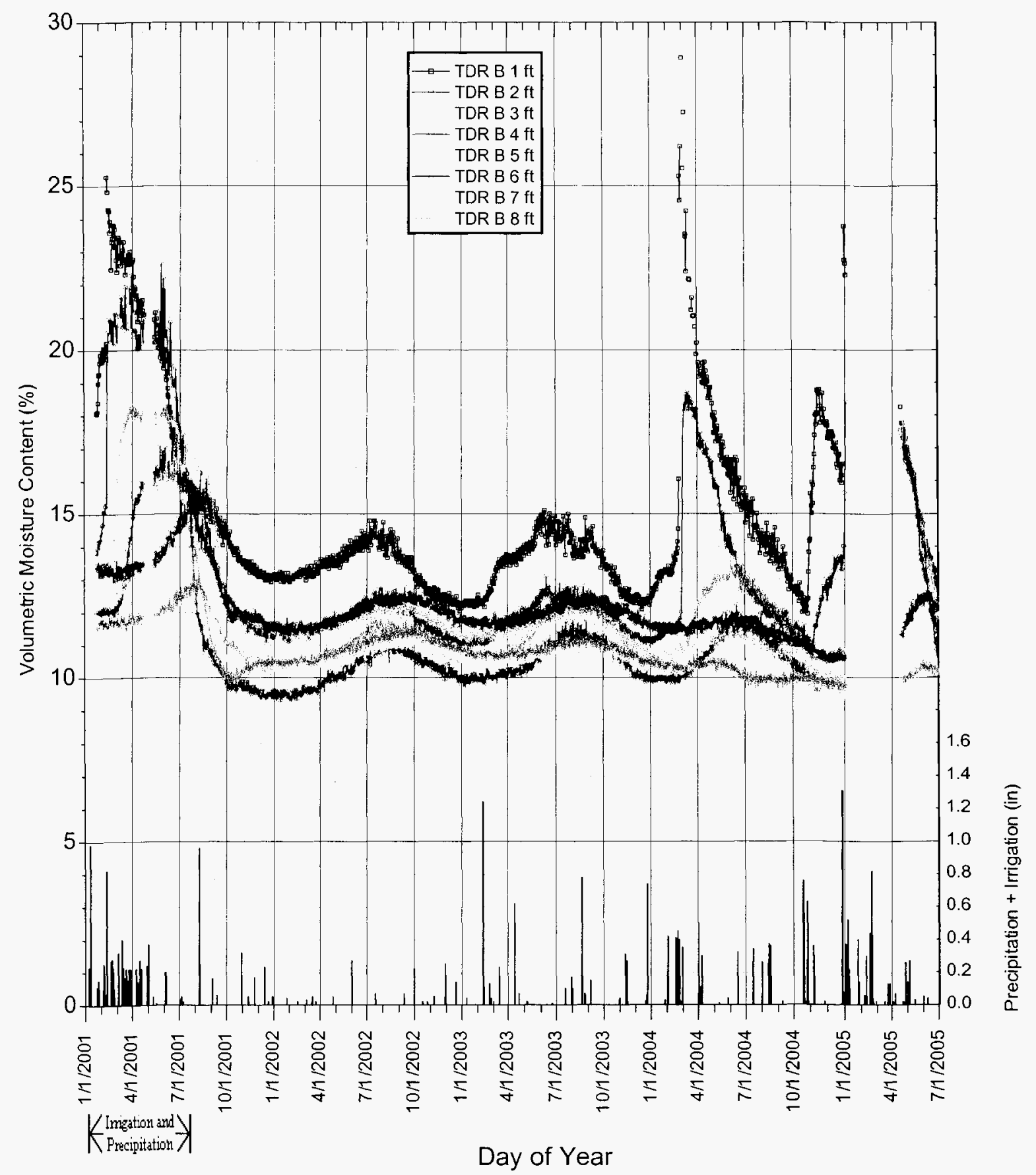

FIGURE 8

WEST TDR NEST B SOIL MOISTURE CONTENT 
The TDR data indicate that the soil moisture content in the CAU 110 cover had been approaching steady-state under the prior drought conditions. A small amount of infiltration from the January through March 2005 precipitation events has reached down to $2.1 \mathrm{~m}(7 \mathrm{ft})$ in the cover at some of the TDR nests, and can be seen as a 2 percent increase in soil moisture content at $2.4 \mathrm{~m}(8 \mathrm{ft})$ in the East TDR Nest A data. Soil moisture content values on the TDR nests at depth are generally between 10 and 15 percent VMC, while moisture content on near surface probes increased significantly due to the heavy precipitation received between January and March 2005. Moisture content values between 25 and 30 percent VMC extended to $1.5 \mathrm{~m}(5 \mathrm{ft}$ ) on all the TDR nests and then showed progressive drying in the near surface to less than 10 percent VMC by the end of June. The wetting front on the West TDR Nest A has caused a loss of signal due to the high moisture content (greater than 30 percent VMC) at the $1.5-\mathrm{m}(5-\mathrm{ft})$ depth in conductive soil. It is expected that data for this probe will recover as evapotranspiration lowers the soil moisture content and the VMC returns to the normal operating range.

The results obtained to date indicate that the CAU 110 cover is functioning as expected. During this reporting period, the cover has been subjected to above average precipitation and is currently coming back into equilibrium from these events. It is expected that by the end of the next reporting period the soil moisture compliance level can be established. 


\subsection{SUMMARY, CONCLUSIONS, AND RECOMMENDATIONS}

\subsection{SUMMARY}

- Inspections of the CAU 110 cover were performed to identify any significant changes to the unit requiring action. Cracking and settling requiring action was observed, and repairs were performed in October 2004. Although new cracks were observed around these repaired areas during the June inspection, they were below the settling compliance criterion.

- Subsidence surveys in September 2004 and March 2005 indicated a maximum decrease in elevation at SM 5 of $-0.015 \mathrm{~m}(-0.05 \mathrm{ft})$, which is near the limit of resolution of the survey instruments. No substantial overall cover subsidence was observed.

- The site received nearly twice the precipitation than normal for the current monitoring period.

- The plant community on the cover is well established. Plant cover is 75 percent higher this year than it was last year. Plant density is the highest since the site was seeded, and the density of annual plants was measured at 100 plants per square meter.

- Soil moisture contents for the TDR nests at depth are generally between 10 and 15 percent VMC. Moisture content values between 25 and 30 percent VMC extended to $1.5 \mathrm{~m}(5 \mathrm{ft})$ on all the TDR nests and then showed progressive drying in the near surface to less than 10 percent VMC by the end of June.

- All posted warning signs and site fencing are in good repair.

\subsection{CONCLUSIONS}

- The new cracks that have formed around previously repaired areas of settling will be monitored closely for additional settling.

- Significant subsidence to the cover has not occurred.

- Plant cover has increased to over 20 percent, well above the goal of 12 percent. There is no indication that remedial revegetation is necessary.

- Soil moisture results obtained to date indicate that the CAU 110 cover is functioning as expected. The cover has been subjected to above average precipitation and is currently coming back into equilibrium from these events. It is expected that by the end of the next reporting period the soil moisture compliance level can be established.

\subsection{RECOMMENDATIONS}

- Continue to monitor the vegetated cover annually to evaluate plant cover, density, and diversity.

- Continue to closely monitor repaired areas during scheduled inpsections for further evidence of settling and need for repair as required. 
Post-Closure Report - CAU 110

Revision: 0

Date: August 2005

- Continue TDR data collection until the cover comes back into equilibrium after the heavy precipitation experienced this reporting period. Establish a compliance level when this occurs. 


\subsection{REFERENCES}

DOE, see U.S. Department of Energy.

EPA, see U.S. Environmental Protection Agency.

FFACO, see Federal Facility Agreement and Consent Order.

Federal Facility Agreement and Consent Order. 1996 (as amended). Agreed to by the State of Nevada, the U.S. Department of Energy, and the U.S. Department of Defense.

NDEP, see Nevada Division of Environmental Protection.

NNSA/NV, see U.S. Department of Energy, National Nuclear Security Administration Nevada Operation Office.

Nevada Division of Environmental Protection. 2000. Permit For a Hazardous Waste Facility, Permit Number NEV HW009; Section VII.B.7, Carson City, NV.

U.S. Department of Energy, Nevada Operations Office. 1988. "Radioactive Waste Management," DOE Order 5820.2A, U.S. Department of Energy, Washington, D.C.

U.S. Department of Energy, Nevada Operations Office. 1999. "Radioactive Waste Management," DOE Order 435.1, U.S. Department of Energy, Washington, D.C.

U.S. Department of Energy, National Nuclear Security Administration Nevada Operations Office. 2001. Closure Report for Corrective Action Unit 110: Area 3 RWMS U-3ax/b1 Disposal Unit, Nevada Test Site, Nevada, DOE/NV--733, Revision 1. August 2001. Las Vegas, NV.

U.S. Environmental Protection Agency. 1996. Title 40 Code of Federal Regulations 265.90, Interim Status Standards for Owners and Operators of Hazardous Waste Treatment, Storage and Disposal Facilities Ground Water Monitoring, Washington, D.C. 
Post-Closure Report - CAU 110

Revision: 0

Date: August 2005

THIS PAGE INTENTIONALLY LEFT BLANK 
Post-Closure Report - CAU 110

Revision: 0

Date: August 2005

\section{APPENDIX A}

\section{INSPECTION CHECKLISTS, FIELD NOTES, AND PHOTOGRAPHS}


Post-Closure Report - CAU 110

Revision: 0

Date: August 2005

THIS PAGE INTENTIONALLY LEFT BLANK 


\section{CAU 110: AREA 3 WMD U-3ax/bl CRATER, POST-CLOSURE INSPECTION CHECKLIST}

\begin{tabular}{|c|c|c|}
\hline \multicolumn{2}{|l|}{ Inspection Date and Time: $9 / 14 / 2004,10: 10$ am } & Reason for Inspection: Quarterly \\
\hline \multicolumn{2}{|l|}{ Date of Last Post-Closure Inspection: $6 / 23 / 2004$} & Reason for Last Post-Closure Inspection: Quarterly \\
\hline \multicolumn{3}{|c|}{ Responsible Agency: Beclntel Nevada Environmental Restoration } \\
\hline \multicolumn{3}{|l|}{ Address: Nevada Test Site. Mercury. Nevada } \\
\hline \multicolumn{3}{|c|}{ Responsible Agency Ofticial: Jeftrey L. Sinith, Project Manager } \\
\hline Chief lnspector: Alissa Tibesar & Title: Technical Lead & Organization: Envirommental Restoration \\
\hline Assistant Inspector: Shaughn Burnison & Title: Task Manager & Organization: Envirommental Restoration \\
\hline \multicolumn{3}{|c|}{ 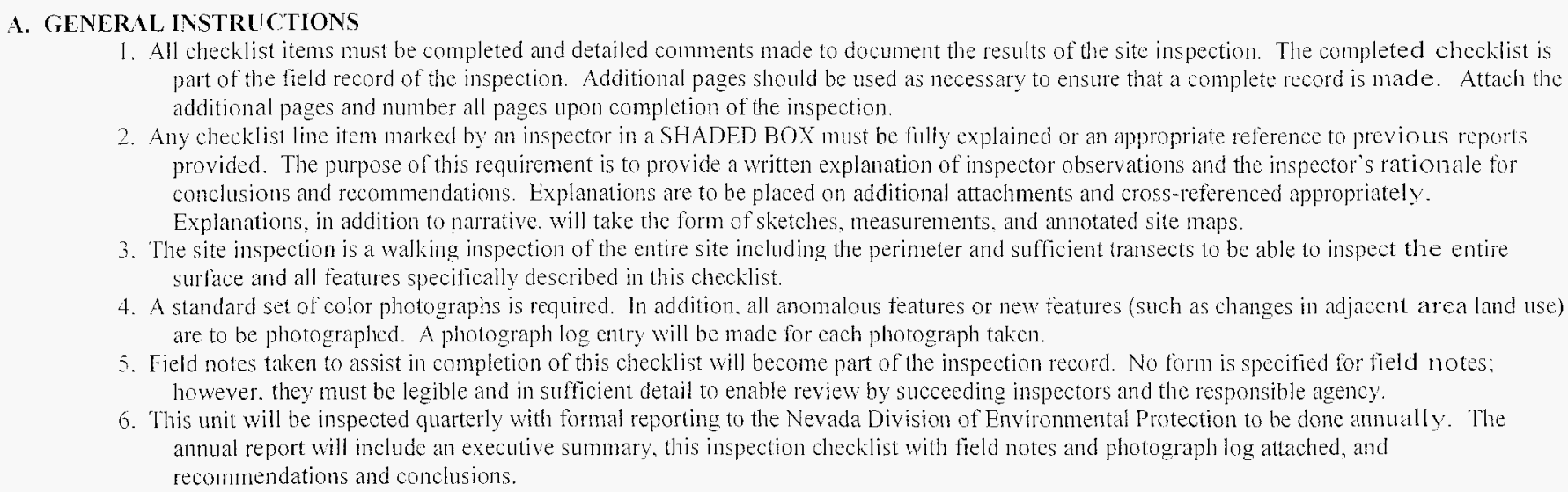 } \\
\hline
\end{tabular}

\begin{tabular}{|c|c|c|c|}
\hline B. PREPARATION (To be competed prior to site visit) & YES & NO & EXPLANATION \\
\hline 1. Has the Post-Closure Permit been reviewed? & $\mathrm{X}$ & & \\
\hline 2. Have the design basis docunents been reviewed? & $\mathrm{X}$ & & \\
\hline 3. Have the site as-built plans and site base map been reviewed? & $\mathrm{X}$ & & \\
\hline \multirow{3}{*}{$\begin{array}{l}\text { 4. Have the previous inspection reports been reviewed? } \\
\text { a. Were anomalies or trends detected on previous } \\
\text { inspections? }\end{array}$} & $\mathrm{X}$ & & \\
\hline & & $\mathrm{X}$ & \\
\hline & & $\mathrm{x}$ & \\
\hline \multirow{3}{*}{$\begin{array}{l}\text { 5. Have the site naintenance and repair records been reviewed"? } \\
\qquad \begin{array}{c}\text { a. Ias site repair resulted in a change from as-built } \\
\text { conditions? } \\
\text { b. Are revised as-built plans available that retlect repair } \\
\text { changes? }\end{array}\end{array}$} & $\mathrm{X}$ & & \\
\hline & & $\mathrm{X}$ & \\
\hline & & $X$ & $N / A$ \\
\hline
\end{tabular}

\section{SITE INSPECTION PREPARATION}

Assemble the following, as needed, to conduct inspections:

a. Camera, film and batteries

b. Keys to locks

c. Clipboard

d. Tape measure

e. Radio, pager, etc.

f. Previous Post-Closure Report. Inspection Checlilists, repair records, and as-built plans

g. Other miscellaneous support equipment 
CAU 110: AREA 3 WMD U-3ax/bI CRATER, POST-CLOSURE INSPECTION CHECKLIST

\begin{tabular}{|l|l|l|l|}
\hline \hline D. SITE INSPECTION & YES & NO & EXPLANATION \\
\hline
\end{tabular}

1. Adjacent off-site features:

a. Have there been any changes in the use of the adjacent area?

b. Are there any new roads or trails?

c. Has there been any change in the position of nearby washes?

d. Has there been lateral excursion or erosion/deposition of nearby washes?

e. Are there new drainage channels?

f. Has there been a change in the surrounding vegetation?

2. Access roads, fences, gates, and signs:

a. Is there a break in the fence?

b. Have any posts been damaged or their anchoring weakened?

c. Does the gate show evidence of tampering or damage?

d. Was the gate locked?

e. Is there any evidence of human intrusion onto the cover?

f. Is there any evidence of large animal intrusion onto the cover?

g. Have any signs been damaged or removed? Number of signs replaced:

h. Other?

\begin{tabular}{|c|c|l||}
\hline & $x$ & \\
\hline & $x$ & \\
\hline & $x$ & \\
\hline & $x$ & \\
\hline & $x$ & \\
\hline & $x$ & \\
\hline
\end{tabular}

\begin{tabular}{|c|c|l|}
\hline & $X$ & \\
\hline & $X$ & \\
\hline & $X$ & \\
\hline$X$ & & \\
\hline & $X$ & \\
\hline & $X$ & \\
\hline & $X$ & \\
\hline & $X$ & \\
\hline & & \\
\hline
\end{tabular}

3. Monuments and other permanent features:

a. Have survey markers, boundary monuments, or monitoring stations been disturbed?

b. Do natural processes threaten the integrity of any survey marker, boundary monument or monitoring station?

c. Is there excessive vegetation around the survey markers, boundary monuments, or monitoring stations?

d. Other?

\begin{tabular}{|c|c|l||}
\hline & $\mathrm{X}$ & \\
\hline & $\mathrm{X}$ & \\
\hline & $\mathrm{X}$ & \\
\hline & $\mathrm{X}$ & \\
\hline
\end{tabular}

4. Waste unit cover:

a. Is there evidence of settling?

b. Is there evidence of cracking?

c. Is there evidence of erosion (wind or water)?

d. Is there evidence of animal burrowing?

c. Is there a change in the vegetation growing on the cover not consistent with the naturally-occurring vegetation growing outside the unit?

g. Other (including trash, debris, etc within fenced area)?

\begin{tabular}{|c|c|l||}
\hline $\mathrm{X}$ & & $\begin{array}{l}\text { Two areas of previously repaired subsidence remain at an actionable } \\
\text { level. Action will be taken. }\end{array}$ \\
\hline $\mathrm{X}$ & & $\begin{array}{l}\text { Cracks at an actionable level are present on the two areas of } \\
\text { subsidence. }\end{array}$ \\
\hline $\mathrm{X}$ & $\mathrm{X}$ & $\begin{array}{l}\text { Animal burrows were noted on the cover, especially at the areas of } \\
\text { subsidence. }\end{array}$ \\
\hline $\mathrm{X}$ & $\mathrm{X}$ & \\
\hline
\end{tabular}




\begin{tabular}{|c|c|c|c|}
\hline \multicolumn{4}{|c|}{ CAU 110: AREA 3 WMD U-3ax/bI CRATER, POST-CLOSURE INSPECTION CHECKLIST } \\
\hline \multicolumn{4}{|l|}{ 5. Photograph Instructions: } \\
\hline \multicolumn{4}{|c|}{$\begin{array}{l}\text { A total of } 8 \text { photographs are required to be taken during each inspection of CAU } 110 \text {. Additional photographs may also be taken. The required } \\
\text { photographs shall be taken as follows: } \\
\text { - Four (4) from the center of the unit, one in each compass direction (i.e., N, S, E, W) and } \\
\text { - Four (4) of the unit from outside the fence, one in each compass direction. }\end{array}$} \\
\hline \multirow{4}{*}{$\begin{array}{l}\text { 6. Photograph Documentation: } \\
\text { a. Have all photographs required by the photograph } \\
\text { instructions been taken? } \\
\text { b. Has a photograph log been prepared? } \\
\text { (Number of photographs taken: 13) }\end{array}$} & YES & No & EXPLANATION \\
\hline & $\mathrm{x}$ & & \\
\hline & $\mathrm{X}$ & & \\
\hline & & $\mathrm{X}$ & \\
\hline \multicolumn{4}{|l|}{ E. FIELD CONCLUSIONS } \\
\hline $\begin{array}{l}\text { 1. Is there an imminent hazard to the integrity of the unit? } \\
\text { (Inmmediate report required) }\end{array}$ & & $\mathrm{x}$ & \\
\hline \multicolumn{4}{|l|}{ Person/Agency to whom report was made: } \\
\hline 2. Are more frequent inspections required? & & $x$ & \\
\hline 3. Are existing maintenance/repair actions satisfactory? & & $X$ & $\begin{array}{l}\text { The two areas of previously-repaired subsidence are again at } \\
\text { actionable levels. }\end{array}$ \\
\hline 4. is other maintenance/repair necessary? & $\mathrm{X}$ & & Action will be taken to repair the two areas of subsidence. \\
\hline \multicolumn{4}{|c|}{$\begin{array}{l}\text { 5. Field conclusions/recommendations: The two areas of previously-repaired subsidence will be repaired as soon as practical. Plans are being discussed } \\
\text { about how to most effectively go about this. }\end{array}$} \\
\hline \multicolumn{4}{|l|}{ F. CERTIFICATION } \\
\hline \multicolumn{4}{|c|}{$\begin{array}{l}\text { I have conduction an inspection of CAU } 110 \text {, Area } 3 \text { WMD U-3ax/bl Crater, in accordance with the procedures of the Post-Closure Permit (including the } \\
\text { Post-Closure Plan) as recorded on this checklist, attached sheets, field notes, photographs, and photograph logs. }\end{array}$} \\
\hline Chief Inspector's Signature & & Date: & $9 / 14 / 2004$ \\
\hline Printed Name: Alissa Tibesar & & Title: & Technical Lead \\
\hline
\end{tabular}


10

PROJECT NO.

BOOK NO.

RCA - CAM $91,92,110,112-9 / 14 / 04$

Personal: Asa TiBesaR $(\pi)$

SHAuctith Burnison (TM)

VISITORS: TED ZAFERATOS SKIP RAD

5
TITLE RCRA inspections

Work continued from Page GREG DOYLE

GEORGE DEUKMAGI

Equipment: none

Weather: Sunny, Clear, 80's

Sow: Perform inspections/take photographs of CAU $91,92,110,4112$ 9:00 am -Met at Dorm B

10 discussed sow \& Tailgate safety

Topics: slips/trips, heat stress, bio hazards, buddy systems, communication, level D Modified P PE

$9: 20$ am-Arrived at $\mathrm{CAU} 112$, A23 Hazardous Waste Trenches

5

CAM 112 - Two sign down - New signs will be hung next FY. signs will be rehung as soon as practical Sparse vegetation on covers

No other issues or concerns

10:10 aum-Arrived at Area 3 Ru ms at signed in for escort to $a$ ab

$: 0$

CA U110-A3 WMD U-3ax/bl crater

Photos: 1. Center looking $N$

9. Fire Ant Hill

2. center looking E

10. View from Wedge looking $E$

3. center looking

11. view from Sedge looking

5

4. center looking W

12. view from s edge looking $\omega$

5. Subsidence (East Side) B. view from Wedge loving

7. subsidence (S side)

Ww scientificbinderys8yrs.com

8.

Work continued to Page II

SIGNATURE

DATE $9 / 14 / 04$

DISCLOSED TO AND UNDERSTOOD BY

DATE

WITNESS

DATE 
TITLE RCRA inspections

Work continued from Page 10
PROJECT NO.

BOOK NO.

- Both areas of subsidence continue to be at actionable levels. Soil around edges is tunneling, and animal burrows are prevalent in these areas.

- FRE Ant hills and animal burrows were noted on cover

5

- No other issues or concerns noted.

- Recommend repairing subsidence and killing fire ants.

11:24 am - Signed out of Area 3 Rums

11:40 am -arrived at U-3fi

10

CAl $91-A_{3}$ u-3fi Injection well

Photos:

1. Center looking $N$

7. Animal burrow

2. Center looking $E$

8. 11

15

3. Center looking

9. outside looking

4. Center looking W

10. outside looking E

5. Wellhead looking $N$ II outside looking $S$

6. Wellhead looking outside looking W

- Small animal burrows backfilled during inspection.

20

- No issues or concerns.

12:05 pm -arrived at Decor Pond

CAl 92 - A6 Recon Pond Facility

Photos: 1.outssicle looking 5. Center looking N

2. outside looking 5

6. center looking

3. our gide looking w 7. center looking $S$

25

4 burfocle loving $N$ \&. center looking $W$

(last 4 take w/ disposable $35 \mathrm{~mm}$ camera)

- Animal barricades on fence need repair

- Dead brush in corners

mww.scientifictinderys8yrs.com no other issues or concerns Work continued to Page -

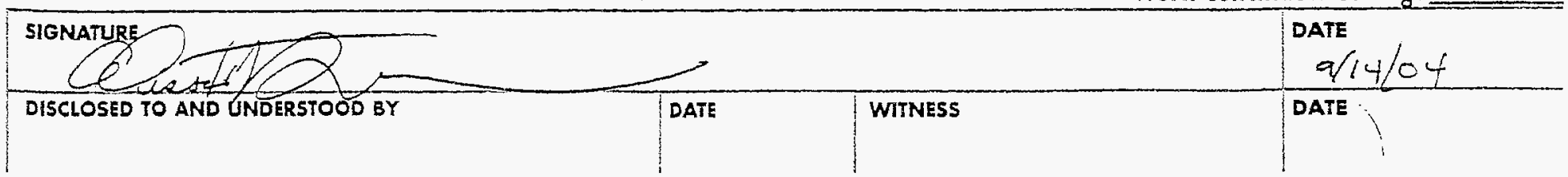


TITLE CAV 110 Repair

Work continued from Page

$$
10 / 25 / 04
$$

Personal - Alissa Tibesar (TL), Shaughn Burnison (TM),

Andy Testing (sup.). Stephen Gibson (Lab.),

charles Williams (lab), Elan Ramos (lab.)

5 Visitors- Ska Rad, George Deukmagi

Equipment -Jumping Jack, loader

weather partly cloudy, 60's, still

Sow. Repairing 2 areas of subsidence; using jumping jack in spiral pattern to collapse piping \& fill in w/ soil (Shovel)

10 8:15- Meet in Dorm D for Safety Meeting to discuss scope of work PTHR was reviewed and signed by craft.

Tailgate safety held by luis Lopez. (FC).

Topics: driving hazards, WMF hazards, slips, trips, falls, cold stress, bio hazards, signs, fencing, subsidence

15 hazards, pinch points, PPE, emergency procedure

9:30 -Arrived at Area 3 RWMS, signed in.

9:50 - Arrived at ax/bl Crater

10:10 -loader dumped dirt from borrow piles to inside fence

- began whacking at southeast area of subsidence

20

- approx. 2 feet from visible edge of cracking

10:20- void space encountered, earth collapsed into void space using shovels.

- 3 large void spaces/tunuels (bottoms were not visible) were uncovered around edge of subsidence 25

25 BOOK NO. 
26

PROJECT NO. BOOK NO.
TITLE CAM 110 Repair

Work continued from Page 25

axil cover:

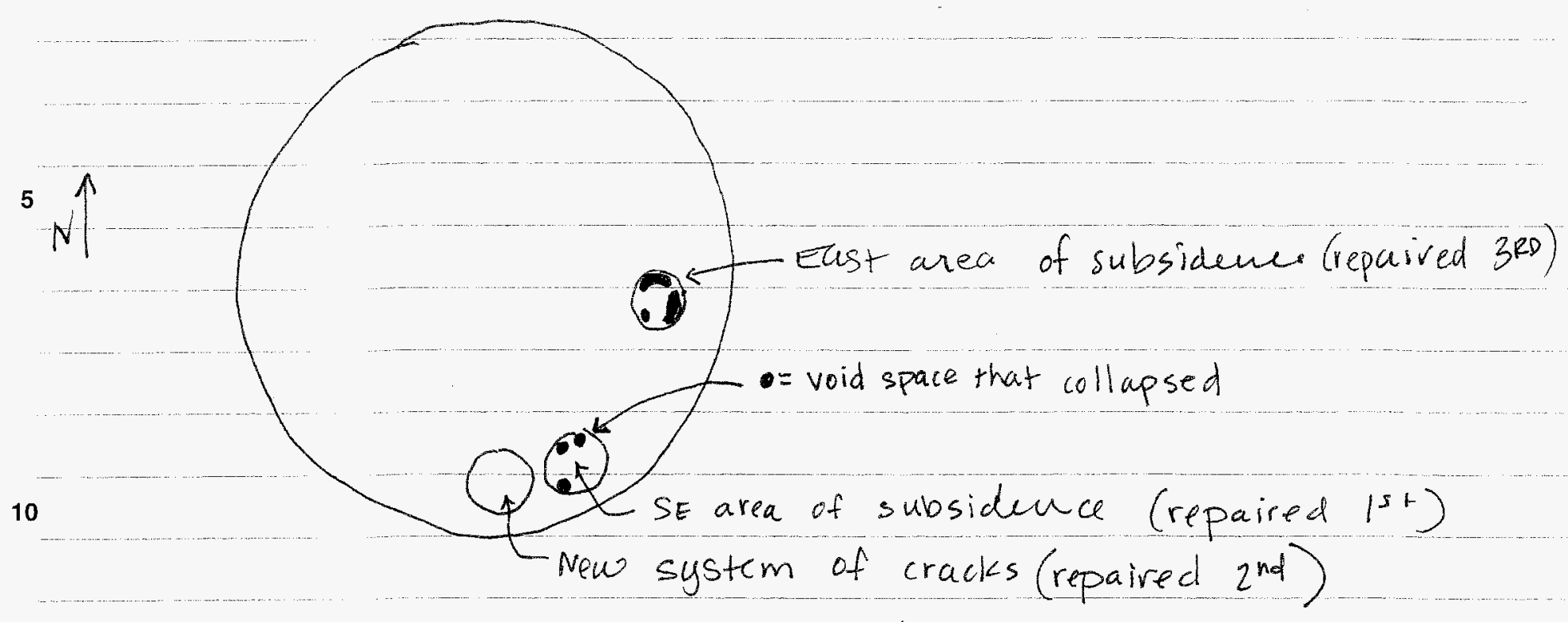

10:50- Soil from borrow pile was brought over by wheel barrow and shoveled into void spaces in SE area of subsidence while new system 15 of cracks was worked on with jumping jack 11:00 - tamped soil fill with jumping jack.

- no void spaces were uncovered at new system of cracks.

12:00- Crew broke for / munch.

${ }^{20} 12: 30$-continued tamping soil to surrounding grade at first 2 areas of subsidence.

1:00 -began tamping East area of subsidence

- void spaces opened up (up to $\backsim 20 \mathrm{ft}$ tunnel lengths) all along outer edges of subsidence area

25

- after shoveling dirt into the exposed tunnels and using the jumping jack, excavations were at about $2 \mathrm{ft}$ bogs.

- all 3 areas were filled to 4 in above grade and

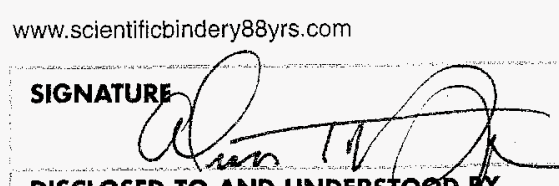

Work continued to Page 27

$$
\text { DATE } 10 / 25 / 0 \%
$$

DISCLOSED TO AND UNDERSTOOD B

DATE

WITNESS

DATE 
TITLE cau 110 Repair

Work continued from Page 26

PROJECT NO.

BOOK NO.

compacted to 2 in above grade. 4:00- completed repaizs Signed out at rowns.

5

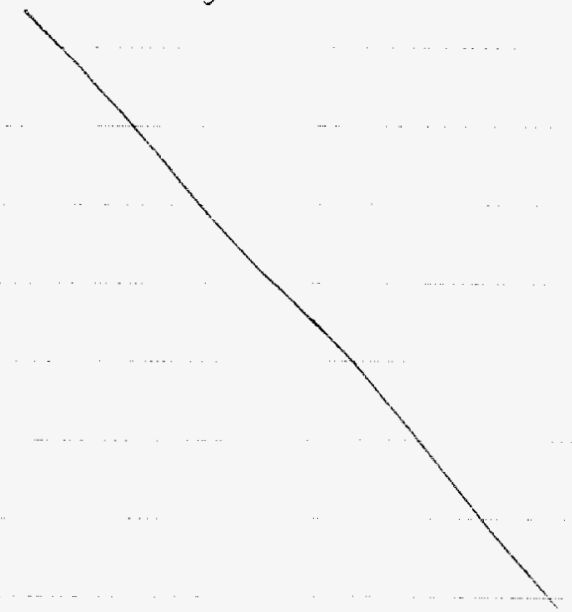

15

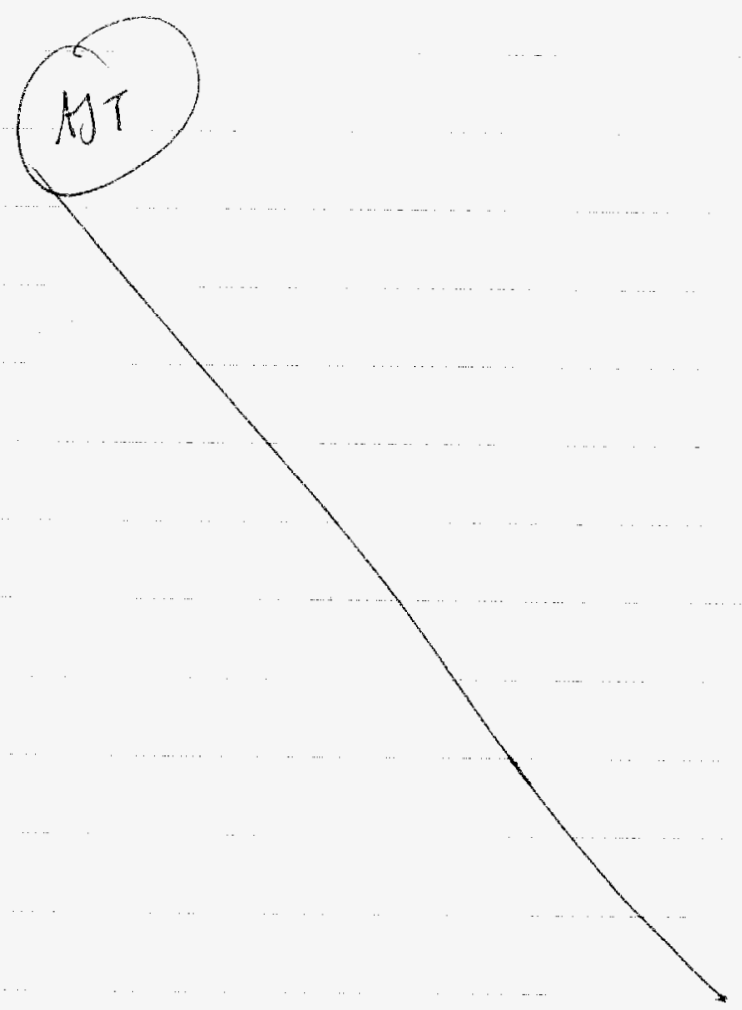

20

www.scientificbindery88yrs.com

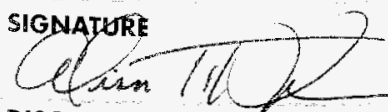

DISCLOSED TO AND UNDERSTOOD BY
DATE

WITNESS
Work continued to Page N/A DATE $10 / 25 / 04$ 
CAU 110: AREA 3 WMD U-3ax/bI CRATER, POST-CLOSURE INSPECTION CHECKLIST

\begin{tabular}{|c|c|c|c|}
\hline Inspection Date and Time: $12 / 14 / 04$ & 945 & \multicolumn{2}{|c|}{ Reason for Inspection: Quarterly } \\
\hline \multicolumn{2}{|c|}{ Date of Last Post-Closure Inspection: $9 / 14 / 04$} & \multicolumn{2}{|c|}{ Reason for Last Post-Closure Inspection: Quarterly } \\
\hline \multicolumn{4}{|c|}{ Responsible Agency: Bcchtel Nevada Environmentai Restoration } \\
\hline \multicolumn{4}{|l|}{ Address: Nevada Test Site. Mercury, Nevada } \\
\hline \multicolumn{4}{|c|}{ Responsible Agency Oflicial: Jeffrey L. Smith, Project Manager } \\
\hline Chief Inspector: ALISSH TBESAR & Title: & $-\angle A A D$ & Organization: Environmental Restoration \\
\hline Assistant Inspector: SHAuctrn BuRnk & Title: 7 & AGER & Organization: Environmental Restoration \\
\hline
\end{tabular}

\section{A. GENERAL INSTRUCTIONS}

1. All checklist items must be completed and detailed comments made to document the results of the site inspection. The completed checklist is part of the field record of the inspection. Additional pages should be used as necessary to ensure that a complete record is made. Attach the additional pages and number all pages upon completion of the inspection.

2. Any checklist line item marked by an inspector in a SHADED BOX must be fully explained or an appropriate reference to previous reports provided. The purpose of this requirement is to provide a written explanation of inspector observations and the inspector's rationale for conclusions and recommendations. Explanations are to be placed on additional attachments and cross-referenced appropriately. Explanations, in addition to narrative, will take the form of sketches, measurements, and annotated site maps,

3. The site inspection is a walking inspection of the entire site including the perimeter and sufficient transects to be able to inspect the entire surface and all features specifically described in this checklist.

4. A standard set of color photographs is required. In addition, all anomalous features or new features (such as changes in adjacent area land use) are to be photographed. A photograph log entry will be made for each photograph taken.

5. Field notes taken to assist in completion of this checklist will become part of the inspection record. No form is specified for field notes; however, they must be legible and in sufficient detail to enable review by succeeding inspectors and the responsible agency.

6. This unit will be inspected quarterly with formal reporting to the Nevada Division of Environmental Protection to be done annually. The annual report will include an executive summary, this inspection checklist with field notes and photograph log attached. and recommendations and conclusions.

B. PREPARATION (To be competed prior to site visit)

1. Has the Post-Closure Permit been reviewed?

2. Have the design basis documents been reviewed?

3. Have the site as-built plans and site base map been reviewed?

4. Have the previous inspection reports been reviewed?

a. Were anomalies or trends detected on previous inspections?

b. Was maintenance performed?

5. Have the site maintenance and repair records been reviewed?

a. Has site repair resulted in a change from as-built conditions?

b. Are revised as-built plans available that reflect repair changes?

\begin{tabular}{|l|l|l||}
\hline YES & NO & EXPLANATION \\
\hline$\checkmark$ & & \\
\hline & & \\
\hline & & \\
\hline & $\checkmark$ & \\
\hline & & Subsidence Repair on $10 / 25 / 04$. \\
\hline & & \\
\hline & $\checkmark$ & \\
\hline & & $N / A$ \\
\hline
\end{tabular}

\section{SITE INSPECTION PREPARATION}

Assemble the following, as needed, to conduct inspections:

a. Camera, film, and batteries

b. Keys to locks

c. Clipboard

d. Tape measure

e. Radio, pager, etc.

f. Previous Post-Closure Report, Inspection Checklists, repair records, and as-built plans

g. Other miscellaneous support equipment 


\section{CAU 110: AREA 3 WMD U-3ax/bI CRATER, POST-CLOSURE INSPECTION CHECKLIST}

\begin{tabular}{|l|l|l|l|l}
\hline D. SITE INSPECTION & YES & NO & EXPLANATION \\
\hline
\end{tabular}

1. Adjacent off-site features:

a. Have there been any changes in the use of the adjacent area?

b. Are there any new roads or trails?

c. Has there been ally change in the position of nearby washes?

d. Has there been lateral excursion or erosion/deposition of nearby washes?

c. Are there new drainage channels?

f. Has there been a change in the surrounding vegetation?

2. Access roads, fences, gates, and signs:

a. Is there a break in the fence?

b. Have any posts been damaged or their anchoring wcakened?

c. Does the gate show evidence of tampering or damage?

d. Was the gate locked?

e. Is there any evidence of human intrusion onto the cover?

f. Is there any evidence of latge animal intrusion onto the cover?

g. Ilave any signs been damaged or removed? (Number of signs replaced:

h. Other?

\begin{tabular}{|l|l|l|}
\hline & $\checkmark$ & \\
\hline & $\checkmark$ & \\
\hline & $\checkmark$ & \\
\hline & $\checkmark$ & \\
\hline & $\checkmark$ & \\
\hline & $\checkmark$ & \\
\hline
\end{tabular}

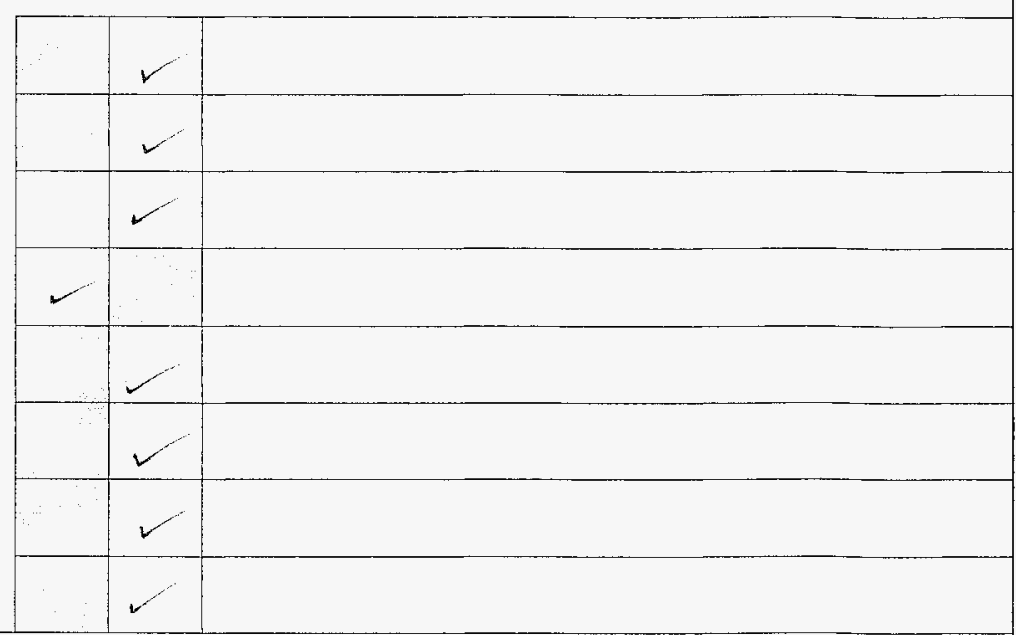

3. Monuments and other permanent features:

a. Have survey markers, boundary monuments, or monitoring stations been disturbed?

b. Do natural processes threaten the integrity of any survey marker, boundary monument or monitoring station?

c. Is there excessive vegetation around the survey markers. boundary monuments, or monitoring stations?

d. Other?

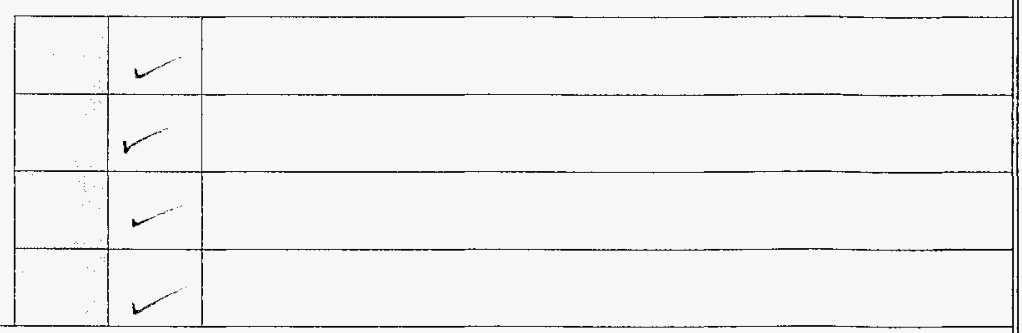

4. Waste unit cover:

a. Is there evidence of settling?

b. Is there evidence of cracking?

c. Is there evidence of erosion (wind or water)?

d. Is there evidence of animal burrowing?

e. Is there a change in the vegetation growing on the cover not consistent with the naturally-occurring vegetation growing outside the unit?

g. Other (including trash, debris. ete within fenced area)?

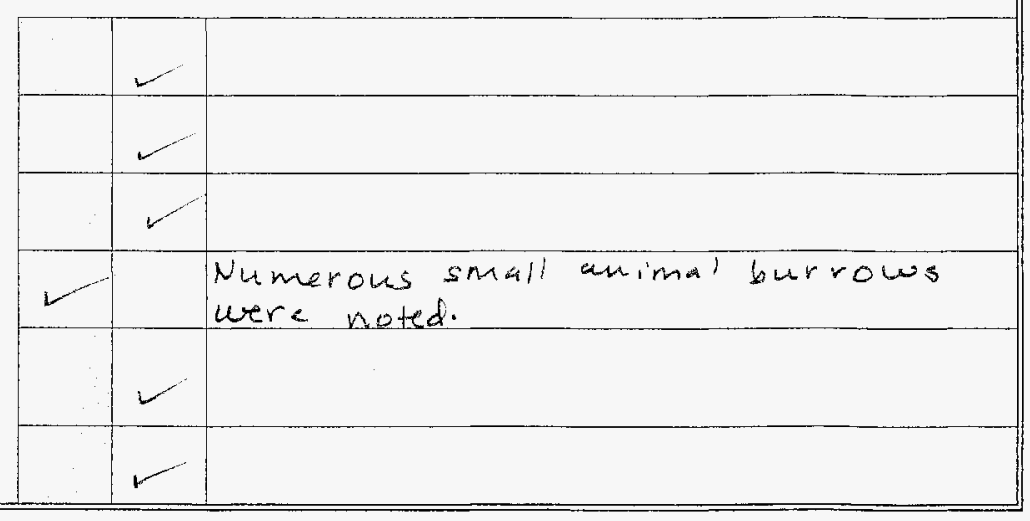




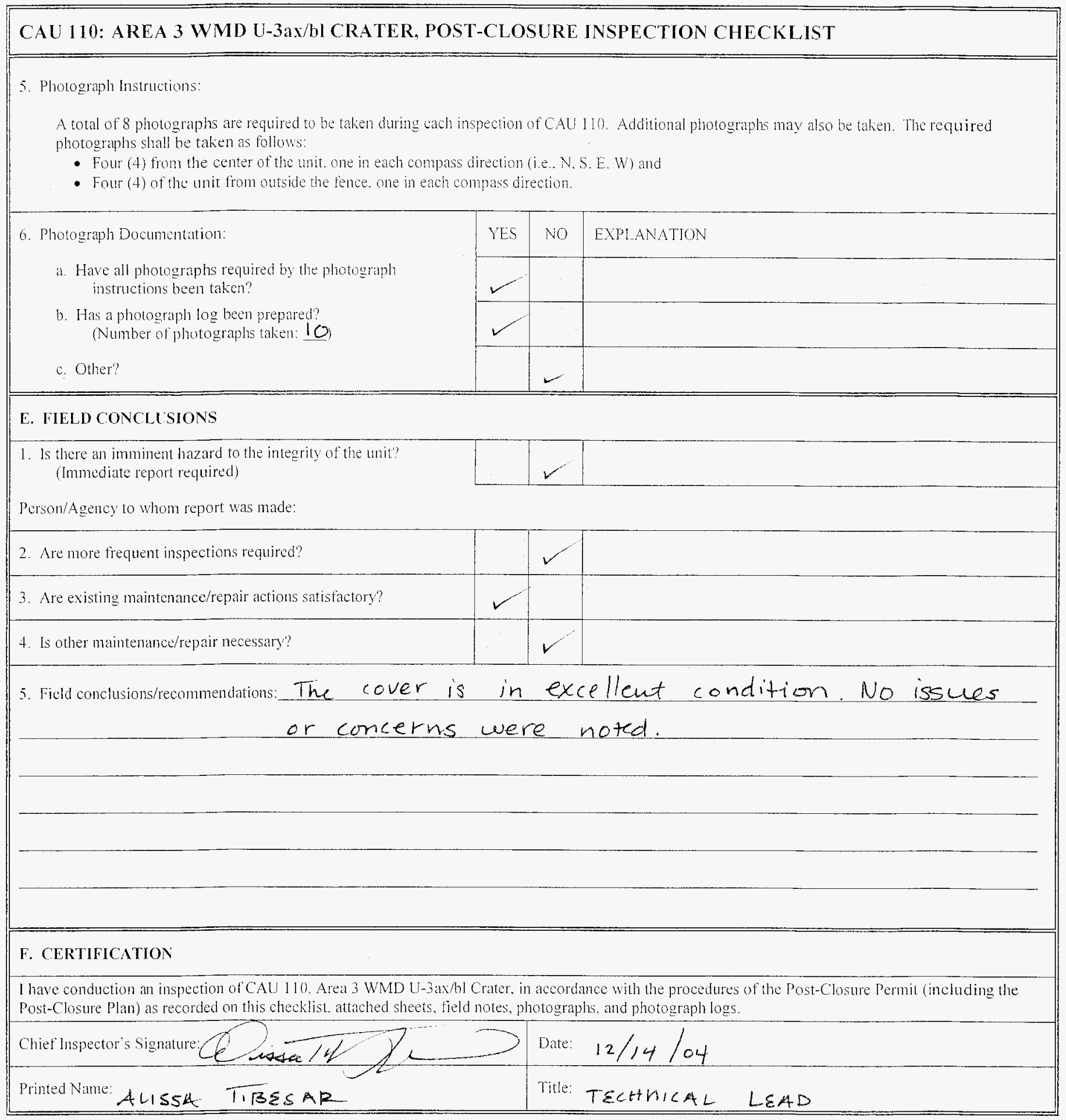


42 PROJECT NO. BOOK NO.

$12 / 14 / 04$

Personal- Alissa Tibesar (TL), Shaughn Buznison (Th), keVin CAmpBelL Visitors - TED ZAFERATOS (NDEP)

EQuipment - DGTML. CAMERA

5 WeAthER-SUnuY, CleAr, 5 's

Sow-Perform RERA inspections:

CA 4 90-Aren 2 Bittier Containment

cu 92 - Area 6 Deacon Pond Facility

CAM 110 -Area 3 WMD U-zax/bl crater

10

940-Arrived at RWMC, signed in and recruited an escort for ax/b/. Photos: center: (1) west

(2) north

(3) east

(1) south

(5) SE Repaired Subsidence- Area

(6) East Repaired Subsidence Area

15 - walked Site. Vegetation is healthy. Different vegetation seems to be growing on TDR nests.

Subsided areas that were repaired in october look good, with no indication of further settling.

Numerous animal burrows were noticed on the cover.

20 - Drove around perimeter of site to inspect signs and fencing and to take photos:

(7) east (8) north (9) west (10) South

All signs and fencing are in excellent condition.

1045 -Arrived at cAll 90 in Area 2

25 photos:

(1) 2

East unit looking $N, \frac{W}{3}, \frac{S}{0}$

West unit looking 5 , $\mathrm{E}$

Walked site. Minor tumbleweeds are present along fence Ww. scientificbindery88yrs.com

Work continued to Page 40

SIGNATURE

DISCLOSED TO AND UNDERSTOOD BY
DATE

12. 14.104

DATE 


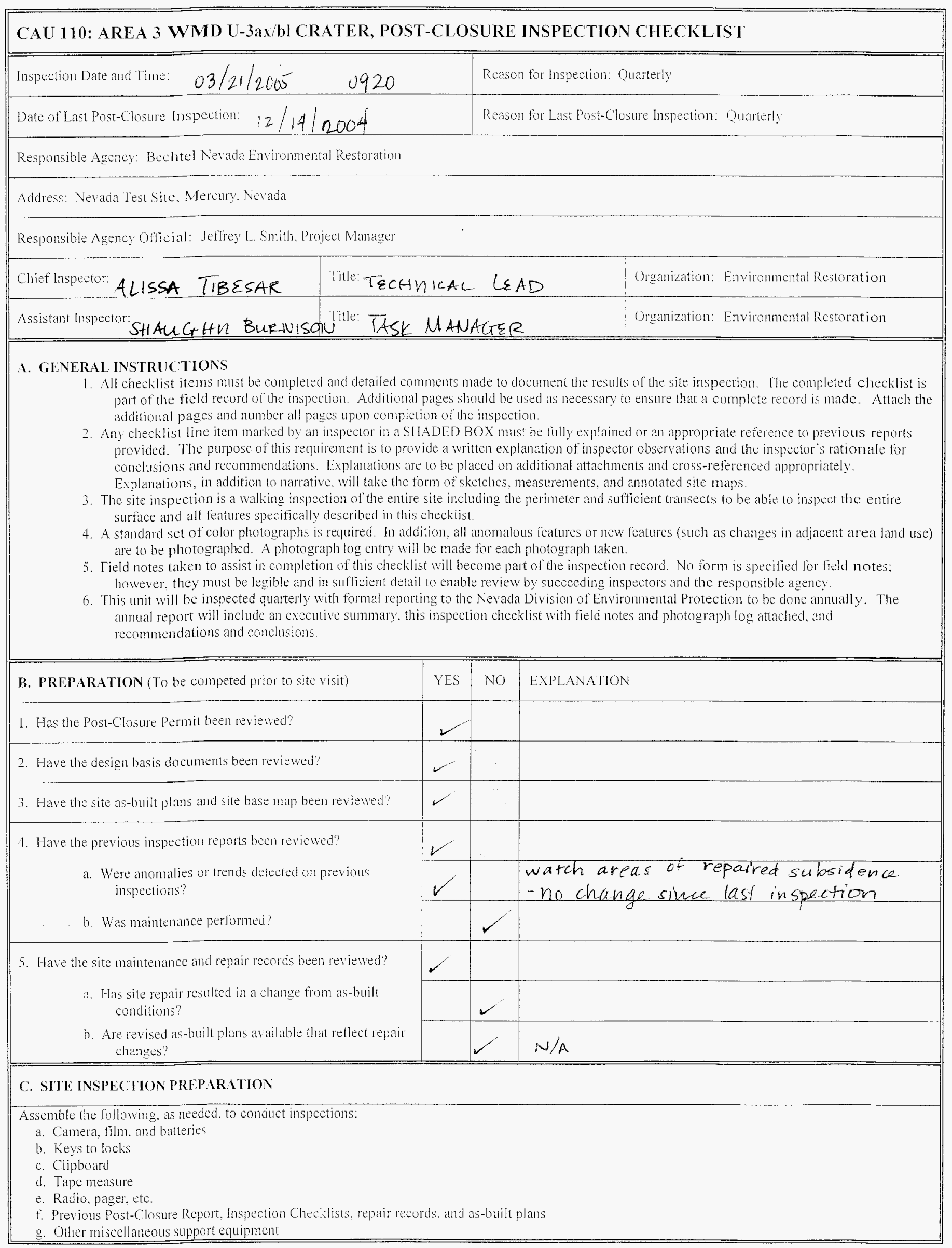




\section{CAU 110: AREA 3 WMD U-3ax/bI CRATER, POST-CLOSURE INSPECTION CHECKLIST}

\begin{tabular}{|l|l|l|l|}
\hline \hline D. SITE INSPECTION & YES & NO & EXPLANATION \\
\hline
\end{tabular}

1. Adjacent off-site features:

a. Have there been any changes in the use of the adjacent area?

b. Are there any new roads or trails?

c. Has there been any change in the position of nearby washes?

d. Has there been lateral excursion or erosion/deposition of nearby washes?

e. Are there new drainage channels?

f. Has there been a change in the surrounding vegetation?

\begin{tabular}{|l|l|l|}
\hline & $\checkmark$ & \\
\hline & $\checkmark$ & \\
\hline & $\checkmark$ & \\
\hline & $\checkmark$ & \\
\hline & $\checkmark$ & \\
\hline & $\swarrow$ & \\
\hline & $\checkmark$ & \\
\hline
\end{tabular}

2. Access roads, fences, gates, and signs:

a. Is there a break in the fence?

b. Have any posts been damaged or their anchoring weakened?

c. Does the gate show evidence of tampering or damage?

d. Was the gate locked?

e. Is there any evidence of human intrusion onto the cover?

f. Is there any evidence of large animal intrusion onto the cover?

g. Have any signs been damaged or removed?

(Number of signs replaced: $\varnothing$ )

h. Other?

\begin{tabular}{|l|l|l|}
\hline & $\swarrow$ & \\
\hline & $\checkmark$ & \\
\hline & $\checkmark$ & \\
\hline$\checkmark$ & & \\
\hline & $\checkmark$ & \\
\hline & $\checkmark$ & \\
\hline & $\swarrow$ & \\
\hline & $\swarrow$ & \\
\hline
\end{tabular}

3. Monuments and other permanent features:

a. Have survey markers, boundary monuments, or monitoring stations been disturbed?

b. Do natural processes threaten the integrity of any survey marker, boundary monument or monitoring station?

c. Is there excessive vegetation around the survey markers, boundary monuments, or monitoring stations?

d. Other?

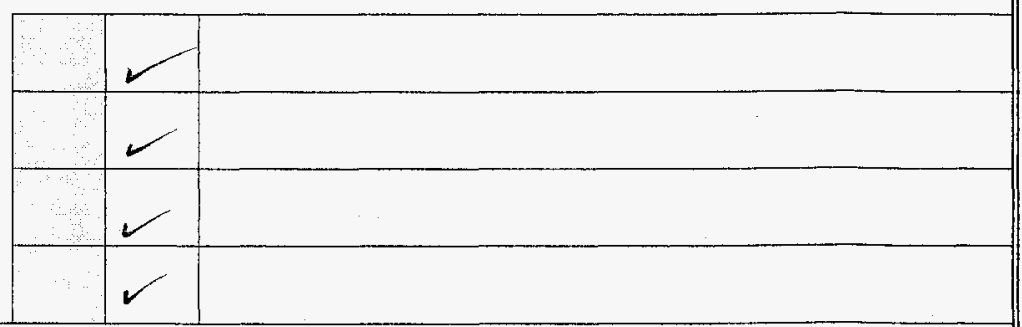

4. Waste unit cover:

a. Is there evidence of settling?

b. Is there evidence of cracking?

c. Is there evidence of erosion (wind or water)?

d. Is there evidence of animal burrowing?

e. Is there a change in the vegetation growing on the cover not consistent with the naturally-occurring vegetation growing outside the unit?

g. Other (including trash, debris, etc within fenced area)?

\begin{tabular}{|l|l|l|}
\hline & $\begin{array}{l}\text { very miror area of potentid } \\
\text { settling wear se instrument }\end{array}$ \\
\hline & $\begin{array}{l}\text { vaut wh beginnings of cracking } \\
\text { around edges. }\end{array}$ \\
\hline$\checkmark$ & \begin{tabular}{l} 
Minor \\
\hline
\end{tabular} \\
\hline
\end{tabular}


Page 3 of 3

CAU 110: AREA 3 WMD U-3ax/bI CRATER, POST-CLOSURE INSPECTION CHECKLIST

5. Photograph Instructions:

A total of 8 photographs are required to be taken during each inspection of CAU 110 . Additional photographs may also be taken. The required photographs shall be taken as follows:

- Four (4) from the center of the unit. one in each compass direction (ice. N. S. F. W) and

- Four (4) of the unit from outside the fence. one in each compass direction.

6. Photograph Documentation:

a. Have all photographs required by the photograph instructions been taken?

b. Has a photograph log been prepared? (Number of photographs taken: /f)

c. Other?

E. FIELD CONCLUSIONS

1. Is there an imminent hazard to the integrity of the unit? (immediate report required)

\begin{tabular}{|l|l|l|}
\hline YES & NO & EXPLANATION \\
\hline & & \\
\hline & & \\
\hline
\end{tabular}

Person/Agency to whom report was made:

2. Are more frequent inspections required?

3. Are existing maintenance/repair actions satisfactory?

4. Is other maintenance/repair necessary"?

5. Field conclusions recommendations: The unit is in excellent condition. No issues or concerns were observed with the fence, signs, monuments, gate, or vegetation. The areas of previously repaired subsidence are in excellent condition with no signs of fur the setting, subsidence, or cracking. The new area of potential settling will be closely monitored. Small animals will be trapped, and ants will be baited in the $2^{\text {nd }}$ Quarter of the (approximately April 05 )

F. CERTIFICATION

I have conduction an inspection of C AU 110 . Area 3 WMD U-3ax/bl Crater in accordance with the procedures of the Post-Closure Permit (including the Post-Closure Plan) as recorded on this checklist. attached sheets. field notes, photographs. and photograph logs.

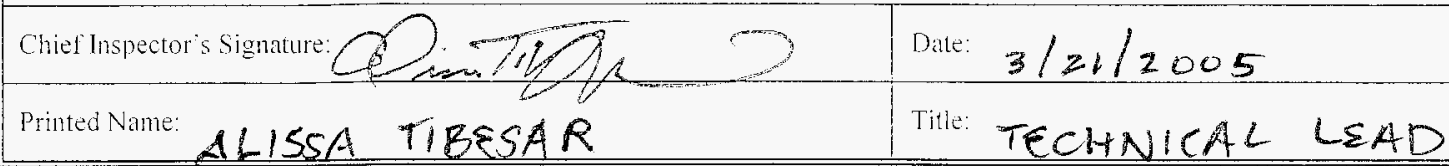


TITER RCRA inspections

Work continued from Page wit

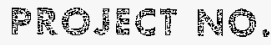

GOOK NO.

G

$3 / 21 / 05$

personnel-Arso Tiber (TC) Sheugh Burmison (Th)

Visitors. Tea zaferatos (MDEP)

Equipment - now

5 weather-sunwy, warn, 60's

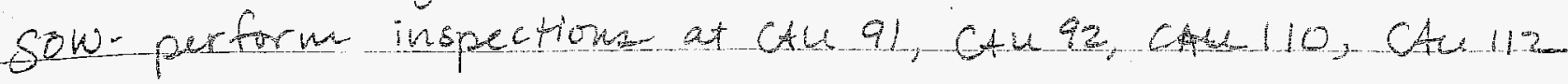

8.30- Wet in Dom $B$

Departed for cardio ax/bl.

9:20 -Signed in at Area 3 Rums

10

Al s 110

The fence and all signs are in excellent condition

The gate was closed and locked.

Vegetation is in excellent condition

Areas of repaired subsidence $100 \mathrm{kgood}$.

15

A few minor animal burrows were preset

Ant hill is currently dormant

Trapping of small animals and baiting of ants is scheduled to be performed in $2^{\text {nd }}$ Quarter.

Area of potential settling/subsidene noticed near southern/eastern 20 instrument vault.

1020 cal 91

The fence and signs are in excellent condition

No debris or vegetation was present inside the fence.

No animal burnous we ne observed.

25

Gate of cook in good condition

No issue or concerns

No maintenance dor of repairs ned ed

Ww.scientificbindery88yrs.com

signarueg.

DISCLOSED TO AND UNDERSTOOD BY
Work continued to Page fo

WITNESS $3 / 2105$

DATE

DATE 


\section{CAU 110: AREA 3 WMD U-3ax/bI CRATER, POST-CLOSURE INSPECTION CHECKLIST}

\begin{tabular}{|l|l|l}
\hline Inspection Date and Time: $6 / 21 / 2005$ & Reason for Inspection: Quarterly \\
\hline Date of Last Post-Closure Inspection: $3 / 21 / 2005$ & Reason for Last Post-Closure Inspection: Quarterly \\
\hline
\end{tabular}

Responsible Agency: Bechtel Nevada Environmental Restoration

Address: Nevada Test Site, Mercury, Nevada

Responsible Agency Official: Jeffrey L. Smith, Project Manager

\begin{tabular}{|l|l}
\hline Chief Inspector: SimuGHAS BuRNuSON & Title: TECA LEAD \\
\hline Assistant Inspector: MiKe FLOYD & Title: TECN LEAD
\end{tabular}

Organization: Environmental Restoration

Organization: Environmental Restoration

\section{A. GENERAL INSTRUCTIONS}

1. All checklist items must be completed and detailed comments made to document the results of the site inspection. The completed checklist is part of the field record of the inspection. Additional pages should be used as necessary to ensure that a complete record is made. Attach the additional pages and number all pages upon completion of the inspection.

2. Any checklist line item marked by an inspector in a SHADED BOX must be fully explained or an appropriate reference to previous reports provided. The purpose of this requirement is to provide a written explanation of inspector observations and the inspector's rationale for conclusions and recommendations. Explanations are to be placed on additional attachments and cross-referenced appropriately. Explanations, in addition to narrative, will take the form of sketches, measurements, and annotated site maps.

3. The site inspection is a walking inspection of the entire site including the perimeter and sufficient transects to be able to inspect the entire surface and all features specifically described in this checklist.

4. A standard set of color photographs is required. In addition, all anomalous features or new features (such as changes in adjacent area land use) are to be photographed. A photograph log entry will be made for each photograph taken.

5. Field notes taken to assist in completion of this checklist will become part of the inspection record. No form is specified for field notes; however, they must be legible and in sufficient detail to enable review by succeeding inspectors and the responsible agency.

6. This unit will be inspected quarterly with formal reporting to the Nevada Division of Environmental Protection to be done annually. The annual report will include an executive summary, this inspection checklist with field notes and photograph log attached, and recommendations and conclusions.

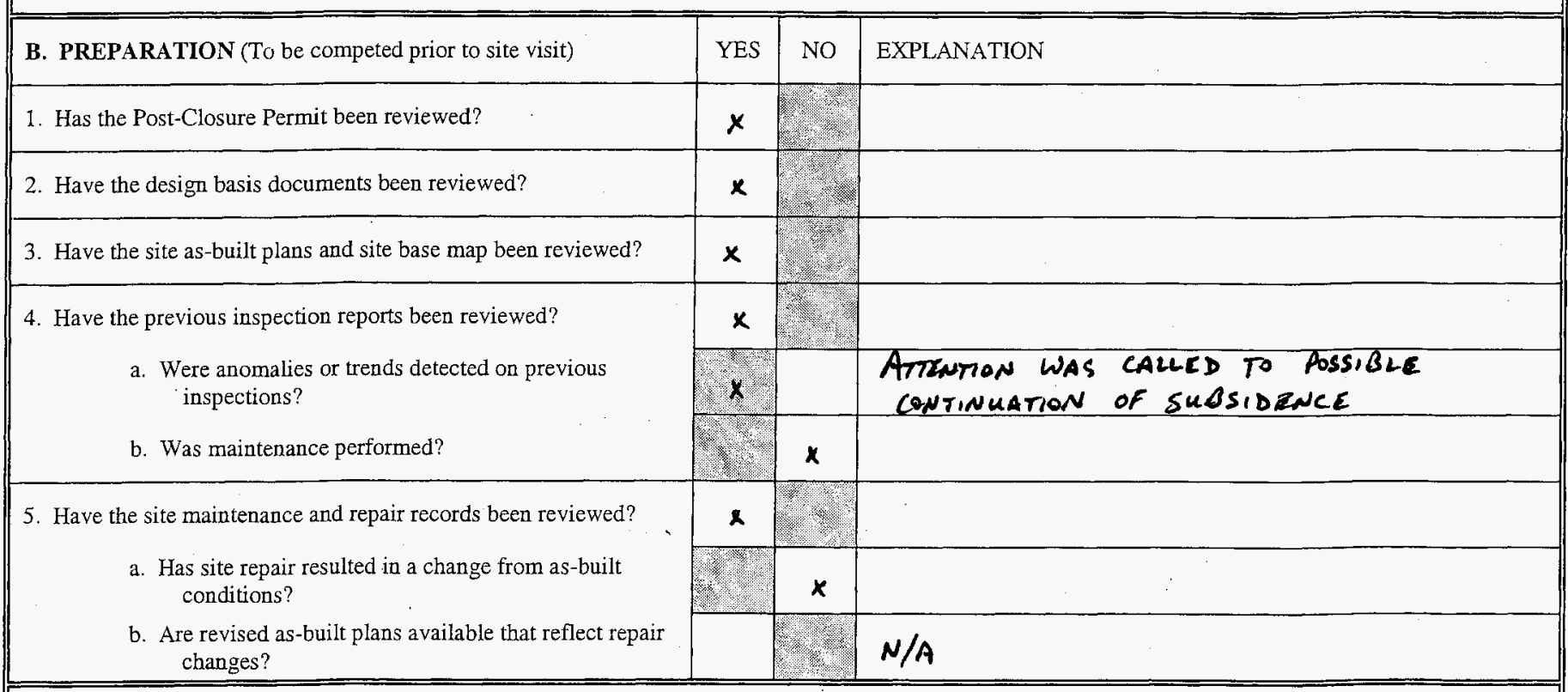

\section{SITE INSPECTION PREPARATION}

Assemble the following, as needed, to conduct inspections:

a. Camera, film, and batteries

b. Keys to locks

c. Clipboard

d. Tape measure

e. Radio, pager, etc.

f. Previous Post-Closure Report, Inspection Checklists, repair records, and as-built plans

g. Other miscellancous support equipment 


\section{CAU 110: AREA 3 WMD U-3ax/bI CRATER, POST-CLOSURE INSPECTION CHECKLIST}

\begin{tabular}{|l|l|l|l|}
\hline D. SITE INSPECTION & YES & NO & EXPLANATION \\
\hline
\end{tabular}

1. Adjacent off-site features:

a. Have there been any changes in the use of the adjacent area?

b. Are there any new roads or trails?

c. Has there been any change in the position of nearby washes?

d. Has there been lateral excursion or erosion/deposition of nearby washes?

e. Are there new drainage channels?

f. Has there been a change in the surrounding vegetation?

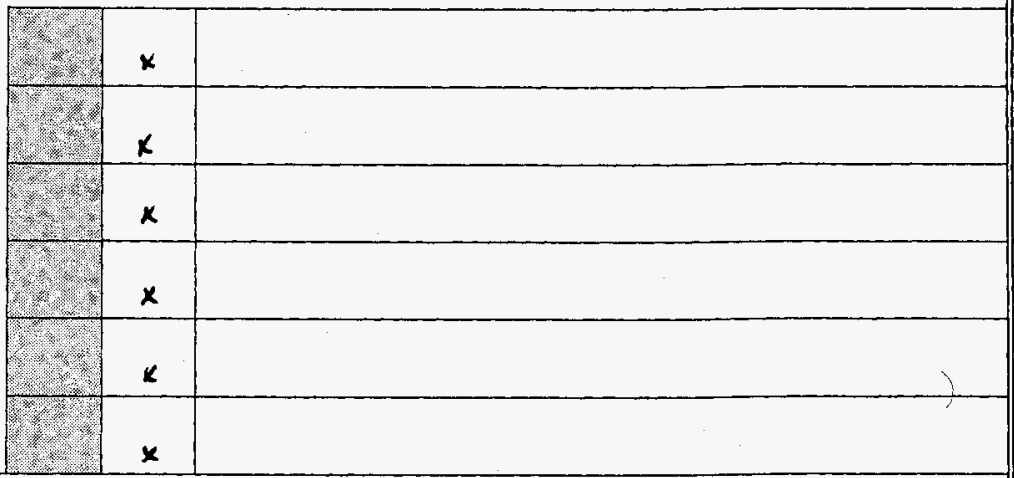

2. Access roads, fences, gates, and signs:

a. Is there a break in the fence?

b. Have any posts been damaged or their anchoring weakened?

c. Does the gate show evidence of tampering or damage?

d. Was the gate locked?

e. Is there any evidence of human intrusion onto the cover?

$f$. Is there any evidence of large animal intrusion onto the cover?

g. Have any signs been damaged or removed?

(Number of signs replaced:

h. Other?

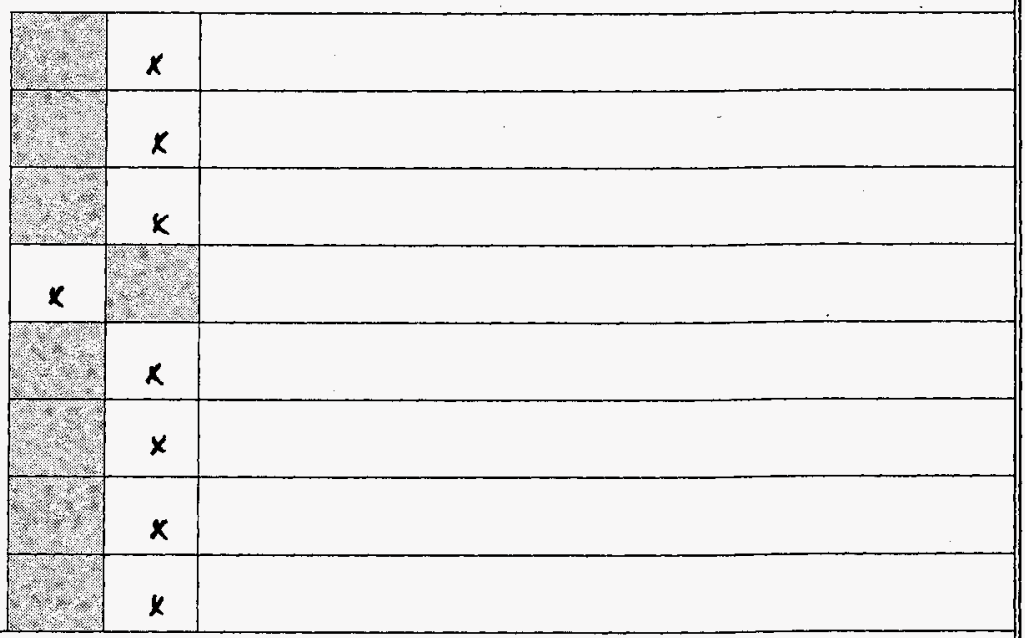

3. Monuments and other permanent features:

a. Have survey markers, boundary monuments, or monitoring stations been disturbed?

b. Do natural processes threaten the integrity of any survey marker, boundary monument or monitoring station?

c. Is there excessive vegetation around the survey markers, boundary monuments, or monitoring stations?

d. Other?

\begin{tabular}{|c|c|l||}
\hline$x$ & $x$ & \\
\hline & $x$ & \\
\hline & $x$ & \\
\hline & $x$ & \\
\hline & & \\
\hline
\end{tabular}

4. Waste unit cover:

a. Is there evidence of settling?

b. Is there evidence of cracking?

c. Is there evidence of erosion (wind or water)?

d. Is there evidence of animal burrowing?

e. Is there a change in the vegetation growing on the cover not consistent with the naturally-occurring vegetation growing outside the unit?

g. Other (including trash, debris, etc within fenced area)?

\begin{tabular}{|c|c|l|}
\hline & $x$ & \\
\hline$x$ & & $\begin{array}{l}\text { A ONE NCH WIDE CRACM HAS DENELOPED ALONG } \\
\text { THE S. EDGE OF YHE NE SUBSIDENCE EUENT }\end{array}$ \\
\hline$x$ & $x$ & THAT WAS REPAIRED LAST SEPTEMBER \\
\hline$x$ & & $\begin{array}{l}\text { MOST SEEM ABAWDONED AFTLR THE TWO } \\
\text { ROUNDS OF MAMMAL MRAPING }\end{array}$ \\
\hline & $x$ & \\
\hline
\end{tabular}




\section{CAU 110: AREA 3 WMD U-3ax/bl CRATER, POST-CLOSURE INSPECTION CHECKLIST}

5. Photograph Instructions:

A total of 8 photographs are required to be taken during each inspection of CAU 110. Additional photographs may also be taken. The required photographs shall be taken as follows:

- Four (4) from the center of the unit, one in each compass direction (i.e., N, S, E, W) and

- Four (4) of the unit from outside the fence, one in each compass direction.

6. Photograph Documentation:

a. Have all photographs required by the photograph instructions been taken?

b. Has a photograph log been prepared? (Number of photographs taken: 8 )

c. Other?

\begin{tabular}{|c|c|c|}
\hline YES & NO & EXPLANATION \\
\hline$x$ & & \\
\hline$x$ & 4 & \\
\hline & & \\
\hline
\end{tabular}

\section{E. FIELD CONCLUSIONS}

1. Is there an imminent hazard to the integrity of the unit? (Immediate report required)

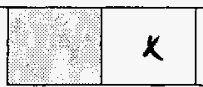

Person/Agency to whom report was made:

\begin{tabular}{|c|c|c|c|}
\hline 2. Are more frequent inspections required? & (2) & $x$ & $\begin{array}{l}\text { A COURTESY INSPRCTION IS PLANUNED } \\
\text { W/IN } 60 \text { DAYS. }\end{array}$ \\
\hline 3. Are existing maintenance/repair actions satisfactory? & $x$ & & \\
\hline 4. Is other maintenance/repair necessary? & $x$ & & TO SEDETERMINED IN AUCUST \\
\hline
\end{tabular}

5. Field conclusions/recommendations: A COURTESY INSPECTON IS DKE IN AUGUST TO EUALUATE AcTONABILITY of THE NE SUBSIDIENCE EUENT.

\section{F. CERTIFICATION}

I have conduction an inspection of CAU 110, Area 3 WMD U-3ax/bl Crater, in accordance with the procedures of the Post-Closure Permit (including the Post-Closure Plan) as recorded on this checklist, attached sheets, field notes, photographs, and photograph logs.

\begin{tabular}{l|l} 
Chief Inspector's Signature: Shafh A. Bumn & Date: $6 / 21 / 2005$ \\
\hline Printed Name: SHAUGHN A. BuRN I SON & Title: FiEAD SUPPORT TECH LEAD
\end{tabular}


TITLE

Work continued from Page 118

CAM $110-43 A X / B L$
PROJECT NO.

BOOK NO.

119

$6 / 21 / 05$

Presonarel: Straugitro BuRNoson - TL

MAKE FLOYD -TL

BRIAN JOERGER - TL

5

RAPT: CAMERA

WEATHIR: SUNAT , go, $10 \mathrm{MPH}$ WIND

SCOPE: QTRLY RCRA INSPECTION

TALGATE: HEAT; SLIPS; BOAZ; ARIA MEDICAL

0

10:05 ARRIVIC $A \times / B C-\operatorname{sen}$ in

Walk cover Excellent vegetation noted. Oval india of cover loots excellent. Fewer small animal turners are

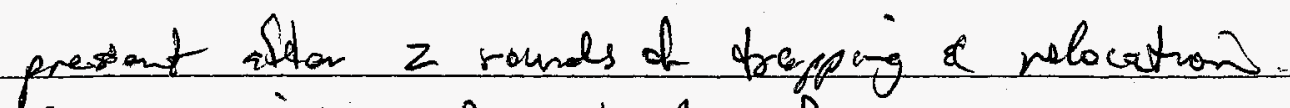

5 Concumnaigation of unit shows faces ot signs to be in excellent condition.

SE Subsidence repair has held. On thy very small snacks. gui evidences of subsurface subsidence progressing show h.

NE sobsidanae repair shows greater evidence of subsurface. subsidence progression. Cracks a 1" wide, of uncrown depth, \& several feat in length are douloping on the South edge of this feature. Cracks were back filled by foot, but a courtesy inspection is apected with on today to evaluate again for antionability.

No other issues or cricorns here.

SCIENTIFIC BINDERY PRODUCTIONS CHICAGO 60605 Made in USA

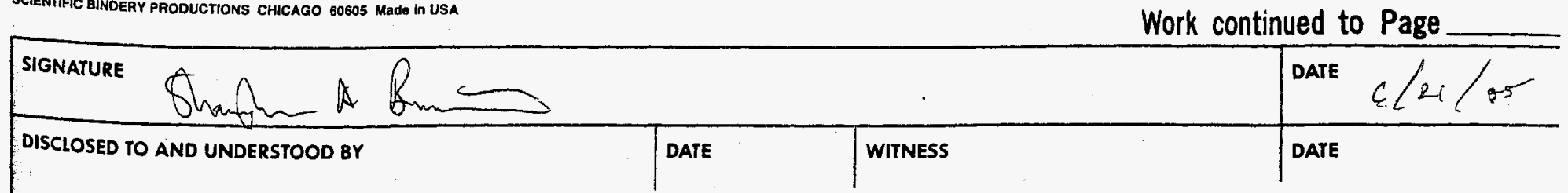




\begin{tabular}{|c|c|c|}
\hline 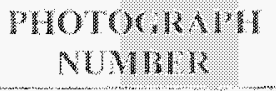 & $10111:$ & WLSCLUTIIN \\
\hline 1 & $09 / 142004$ & Vow hon conter U-3axbl cover looking noth \\
\hline 2 & $00 / 42004$ & Vew from center U-3ax/o cover looking east. \\
\hline 3 & $09 / 42004$ & Vew from center $-3 a x / b l$ cover looking souh \\
\hline 4 & 0914200 & View fron center $1.3 \mathrm{ax} / \mathrm{bl}$ cover looking west \\
\hline 5 & 091200 & 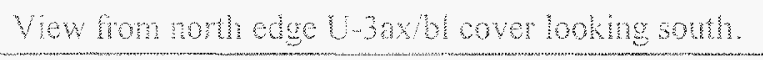 \\
\hline 6 & $09: 12004$ & Vew tron east edge U 3axblover lookng west. \\
\hline 7 & 90112004 & View from south edge U-3axbl covor bokng noth. \\
\hline 8 & $09 / 142004$ & Vew hon mest edge U-3axbl over lookng east. \\
\hline 9 & 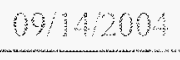 & Subrdene arwalong east side of cover. \\
\hline 10 & 0912004 & Subsideres area along cast side of cover. \\
\hline 1 & $00 / 142004$ & Subsideme area along southeast side of cover. \\
\hline 12 & $09 / 1 / 2004$ & Subsidence area along sombeast side of cover. \\
\hline 1 & $2 / 1,2004$ & Yew from center U-3ax/bl cove lookng norh. \\
\hline 2 & $12 / 142004$ & Vew hom centor U-3ax/bl cover looking cast. \\
\hline 3 & $2 / 12004$ & 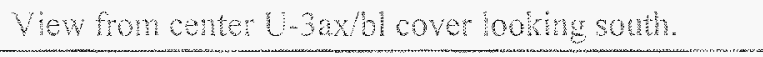 \\
\hline 4 & 12142004 & Vew hon center $\mathrm{H}-3 \mathrm{ax} / \mathrm{b}$ cover looking west. \\
\hline 5 & 12142004 & Wew hom north odge U-3ax/bl cover lookng somh. \\
\hline 6 & 12142004 & Vew trom east adge U-3nol cover looking west. \\
\hline ? & $12 / 2004$ & Wew from south edge U $3 \mathrm{ax}$ bl cover lookng north \\
\hline 8 & 12114004 & Vew from west edge U-3axbl cover lookng east \\
\hline 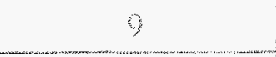 & $12: 12004$ & Substonce area along erst side of cover. \\
\hline 10 & 12142004 & Tho repard are along souneast side of cover. \\
\hline 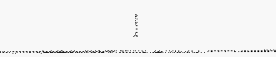 & 33212005 & Vew fom center U-3ax/bl cover bokng nom \\
\hline 2 & 03212005 & Vew from center U-3ak/bl cover looking ens. \\
\hline 3 & 03212005 & Vew fon center U-3axbl cover lookng soutl. \\
\hline 4 & 13212005 & Vew fron coner U-3axbloverloking vesh. \\
\hline 5 & $13 / 2005$ & Vew from nont edge U-3avbl cover lookng sonth. \\
\hline 6 & 3312009 & Vew fom eastedge U-3axhl cover looking west \\
\hline 7 & 03212005 & Vew hom south edge U.3ax/bl sor looking noth. \\
\hline 8 & 03,212005 & Yew hom west edge U 3 axbl cover looking cast \\
\hline 9 & 03212005 & Subsidenes area along eastste or cover. \\
\hline
\end{tabular}




\begin{tabular}{|c|c|c|}
\hline & & 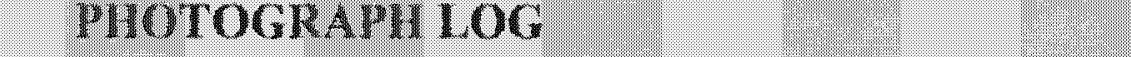 \\
\hline 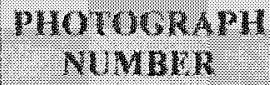 & DARI:?: & 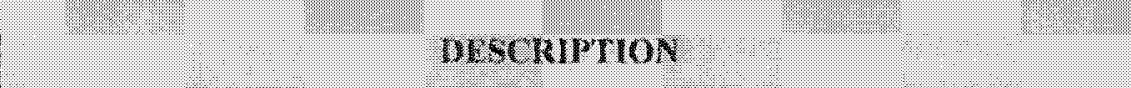 \\
\hline 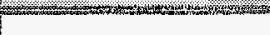 & 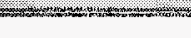 & 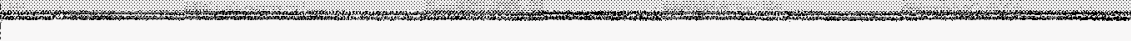 \\
\hline 10 & $03 / 21 / 2005$ & Repaired area along southeast side of cover. \\
\hline 1 & $06 / 21 / 2005$ & View from center U-3ax/bl cover looking north. \\
\hline 2 & $06 / 21 / 2005$ & View from center U-3ax/bl cover looking east. \\
\hline 3 & $06 / 21 / 2005$ & View from center U-3ax/bl cover looking south. \\
\hline 4 & $06 / 21 / 2005$ & View from center U $3 \mathrm{gx} / \mathrm{bl}$ cover looking west. \\
\hline 5 & $06 / 21 / 2005$ & View from month edge U.3ax/bl cover looking south. \\
\hline 6 & $06 / 21 / 2005$ & View from east edge $U-3 \mathrm{ax} / \mathrm{bl}$ cover looking west. \\
\hline 7 & $06 / 21 / 2005$ & View from south edge U.3ax/bl cover looking north. \\
\hline 8 & $06 / 21 / 2005$ & View from west edge U-3ax/bl cover looking sast. \\
\hline
\end{tabular}




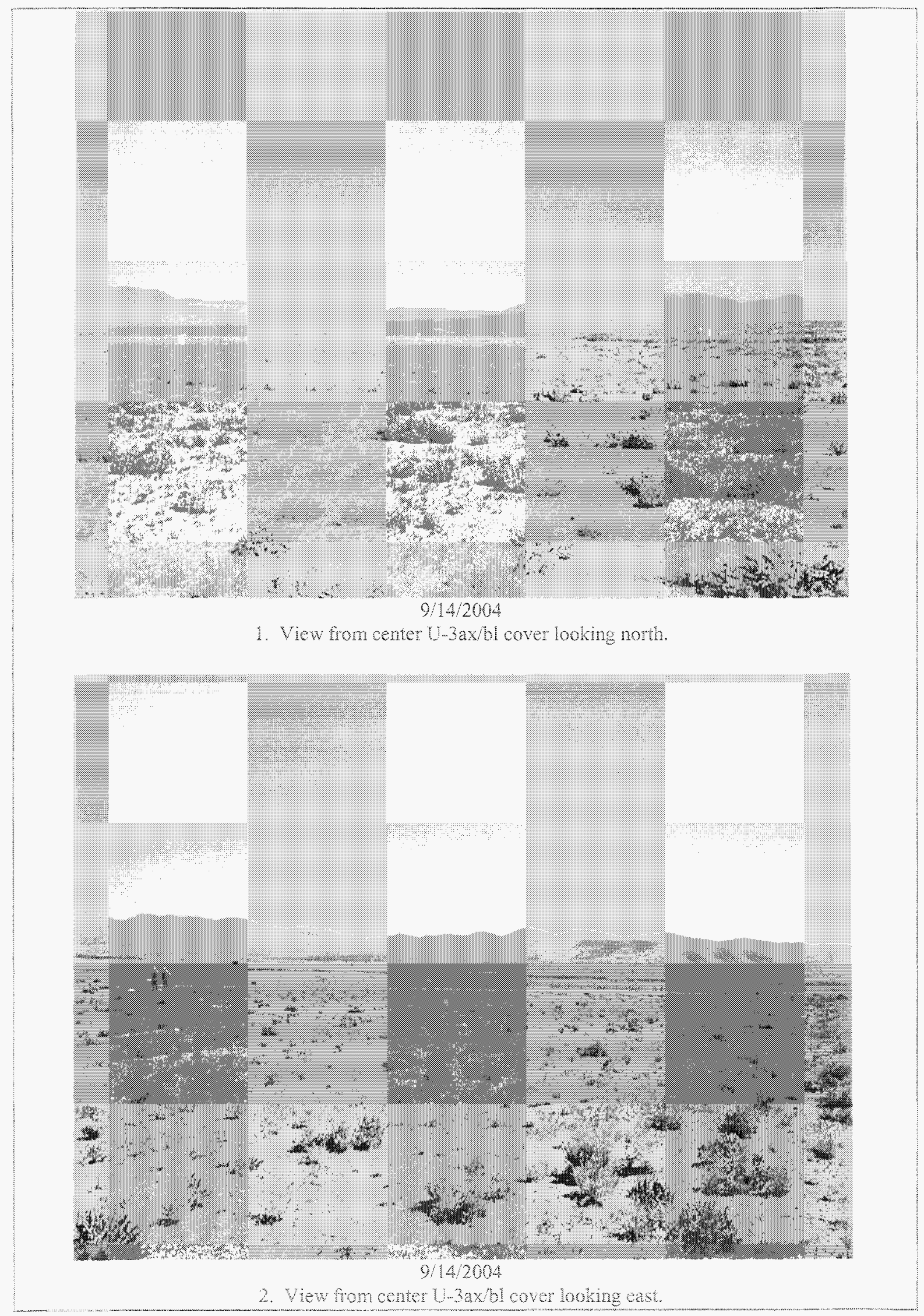


Post-Clocure SRepor - CAU 110

Revision: 0

Date: Augusa 2005

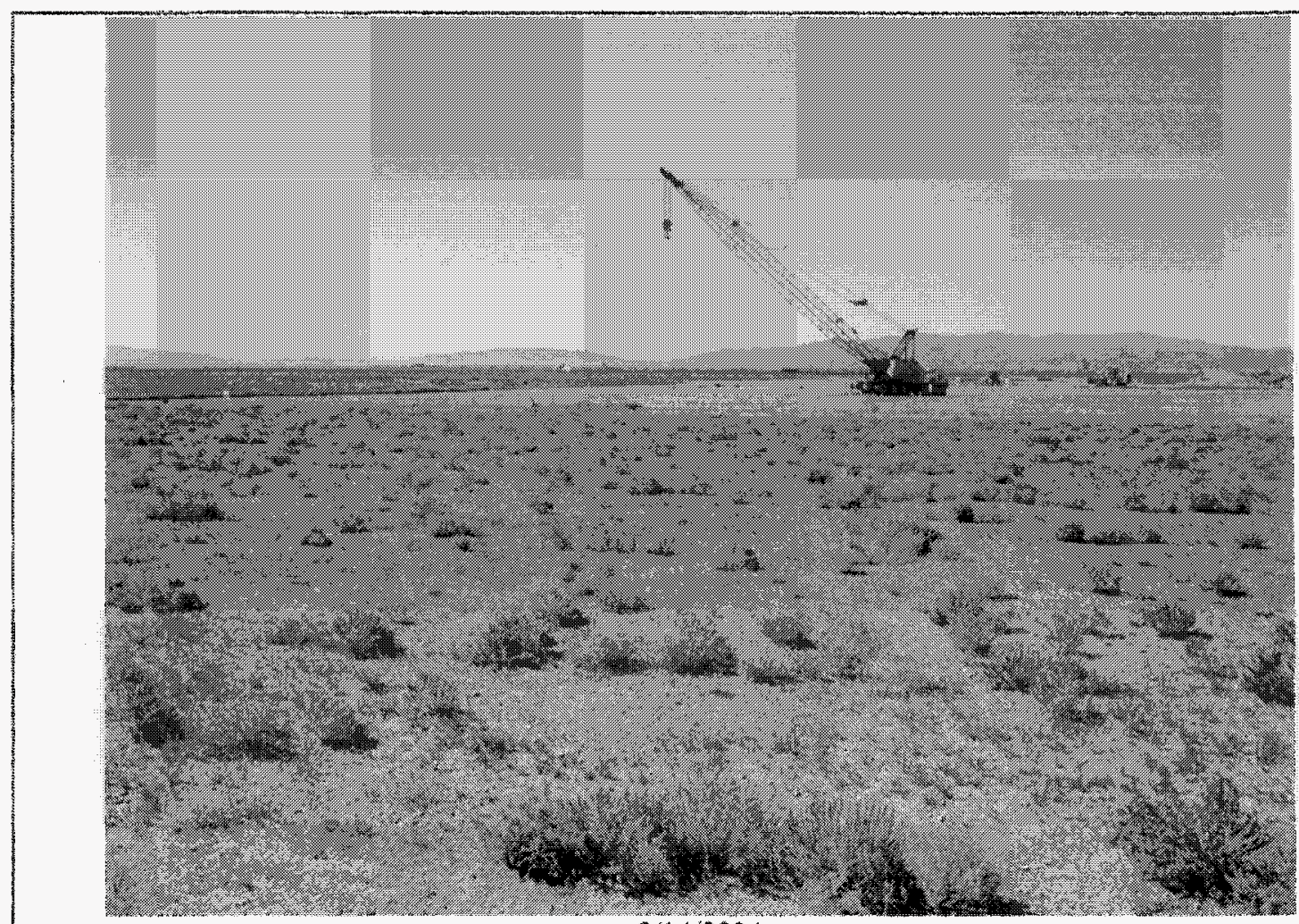

$9 / 14 / 2004$

3. View from center $U-3 a x / b 1$ cover looking south.

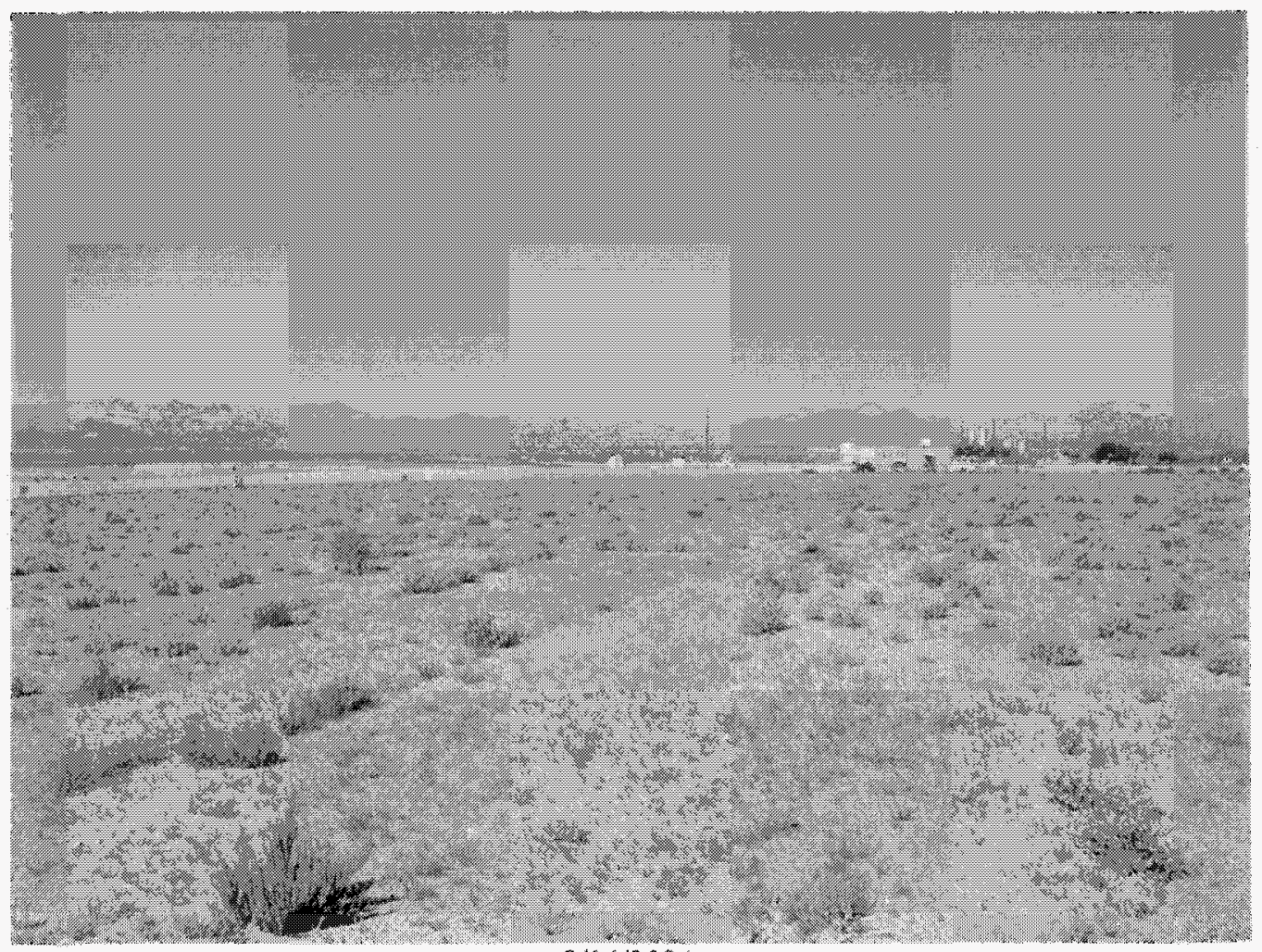

$9 / 14 / 2004$

4. View from center U-3ax/bl cover looking west. 


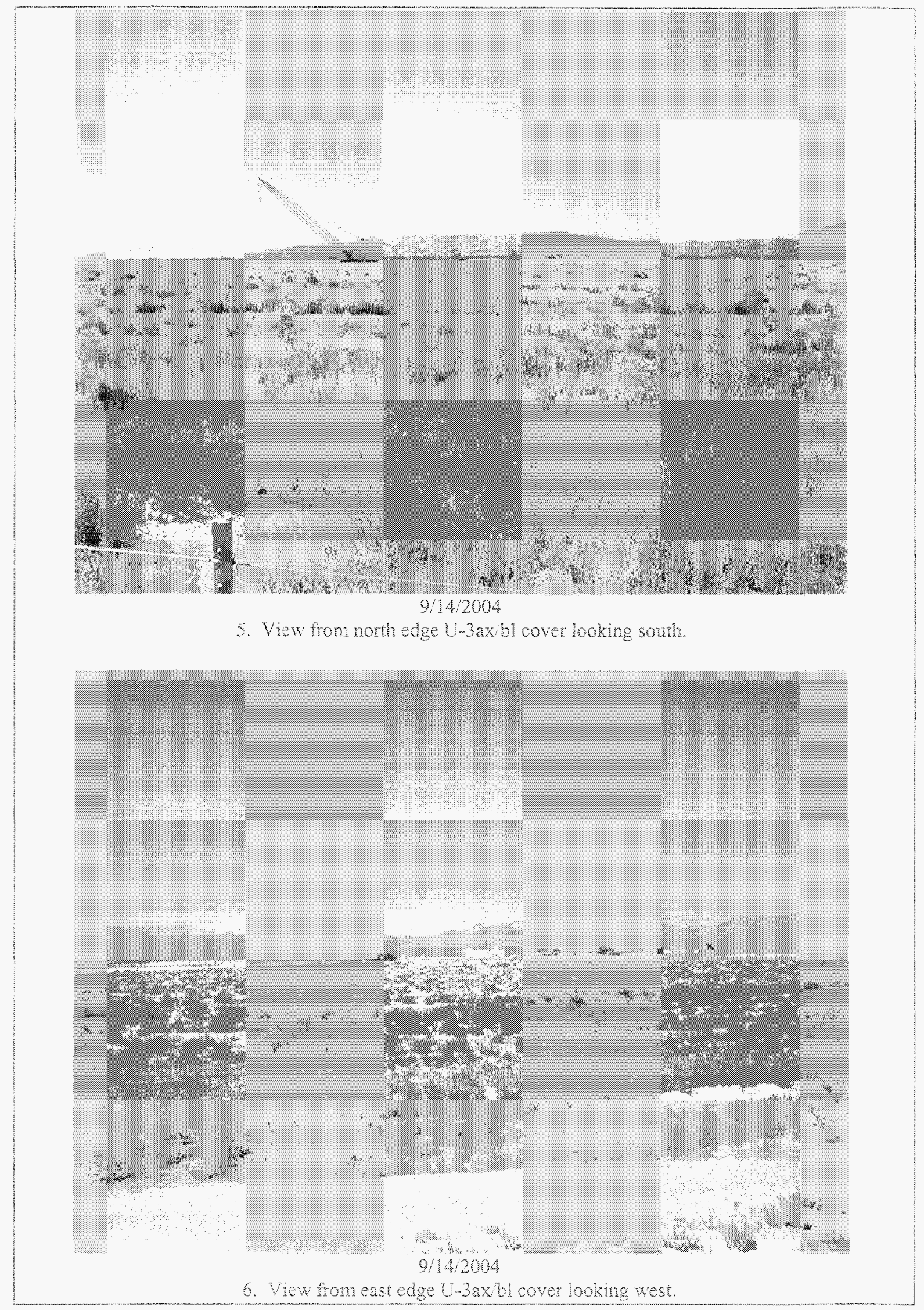


Post-Closure Revort - CAU 110

Revision: 0

Date: August 2005

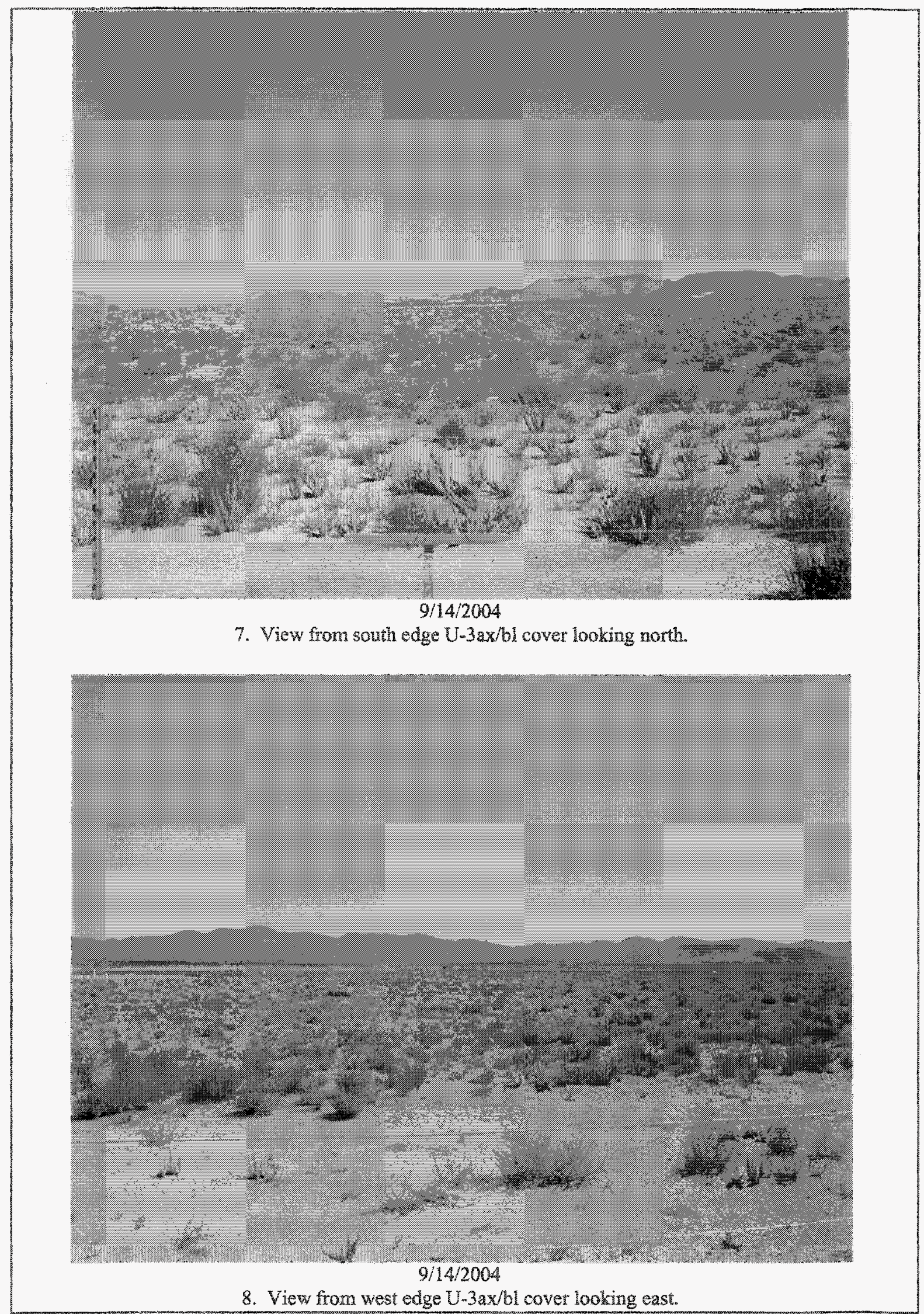




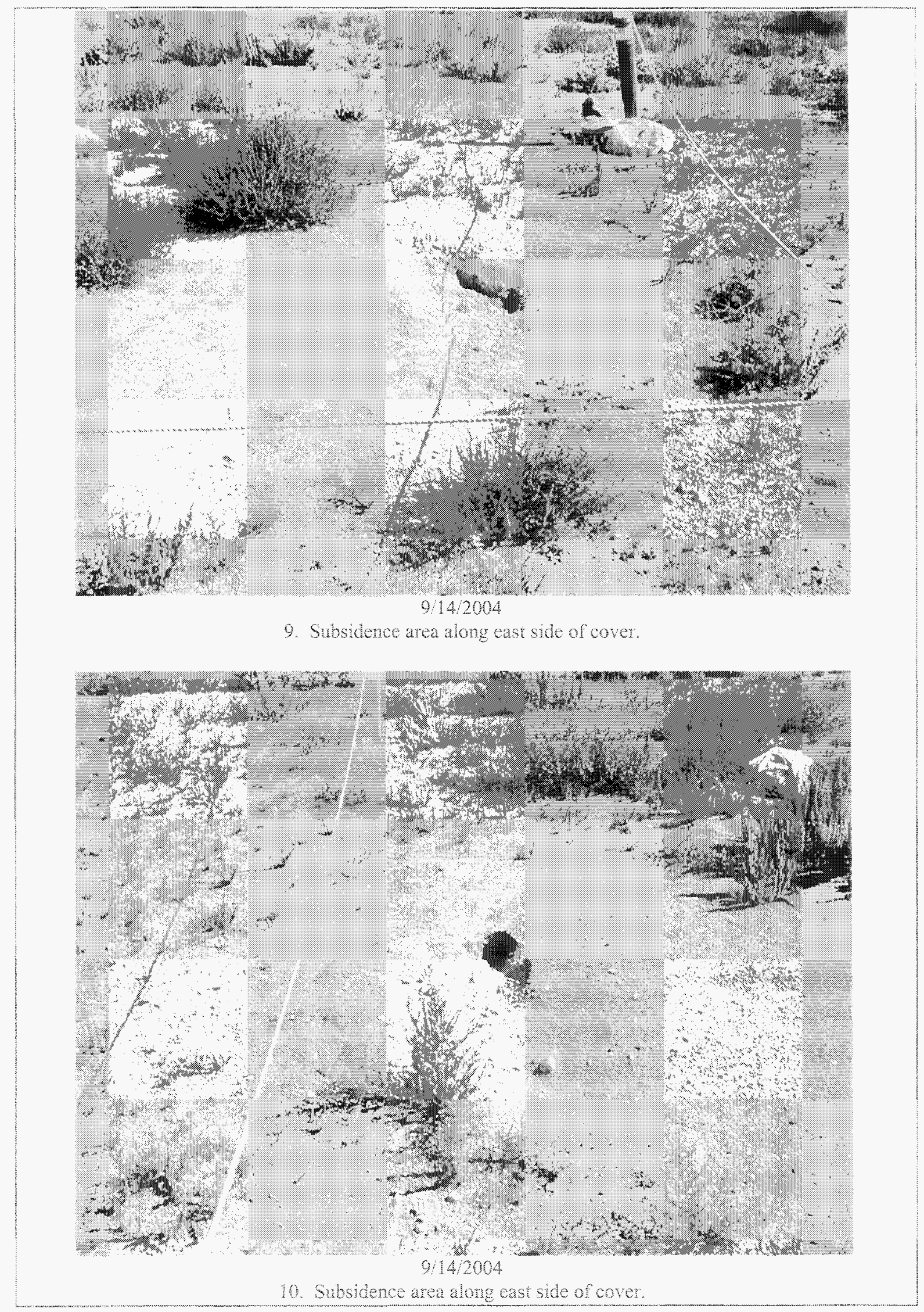




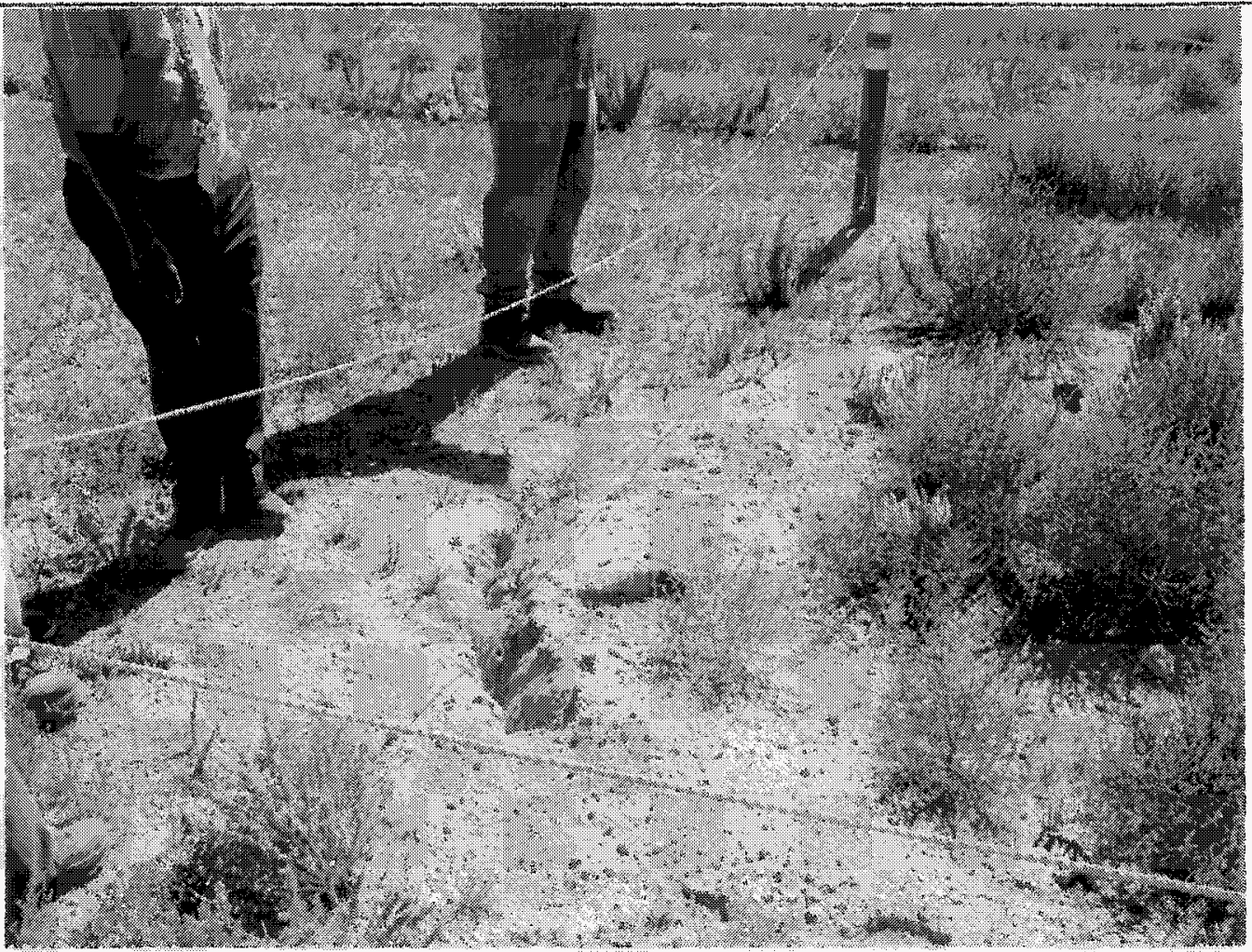
$9 / 14 / 2004$

11. Subsidence area along southeast side of cover.

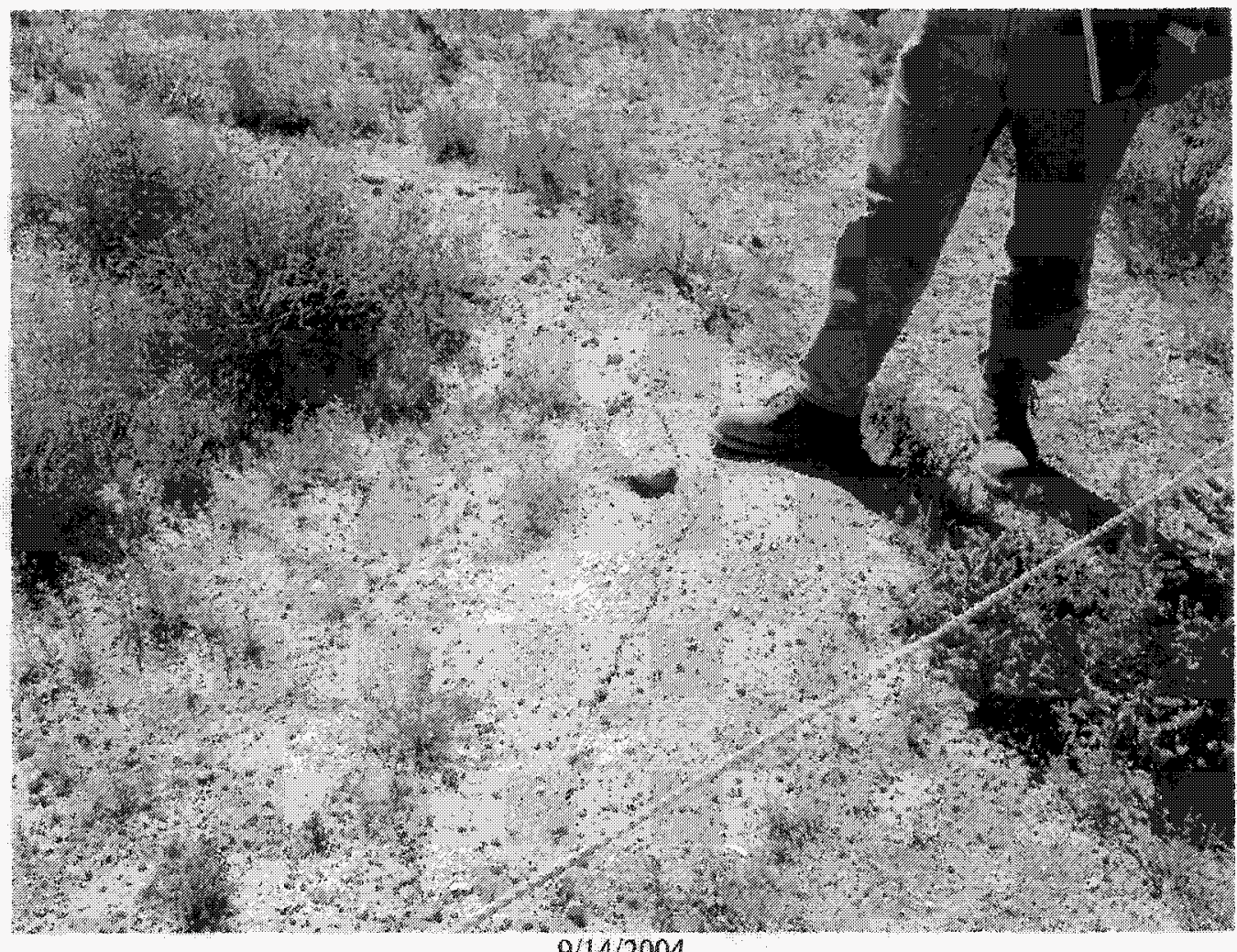

12. Subsidence area along southeast side of cover. 


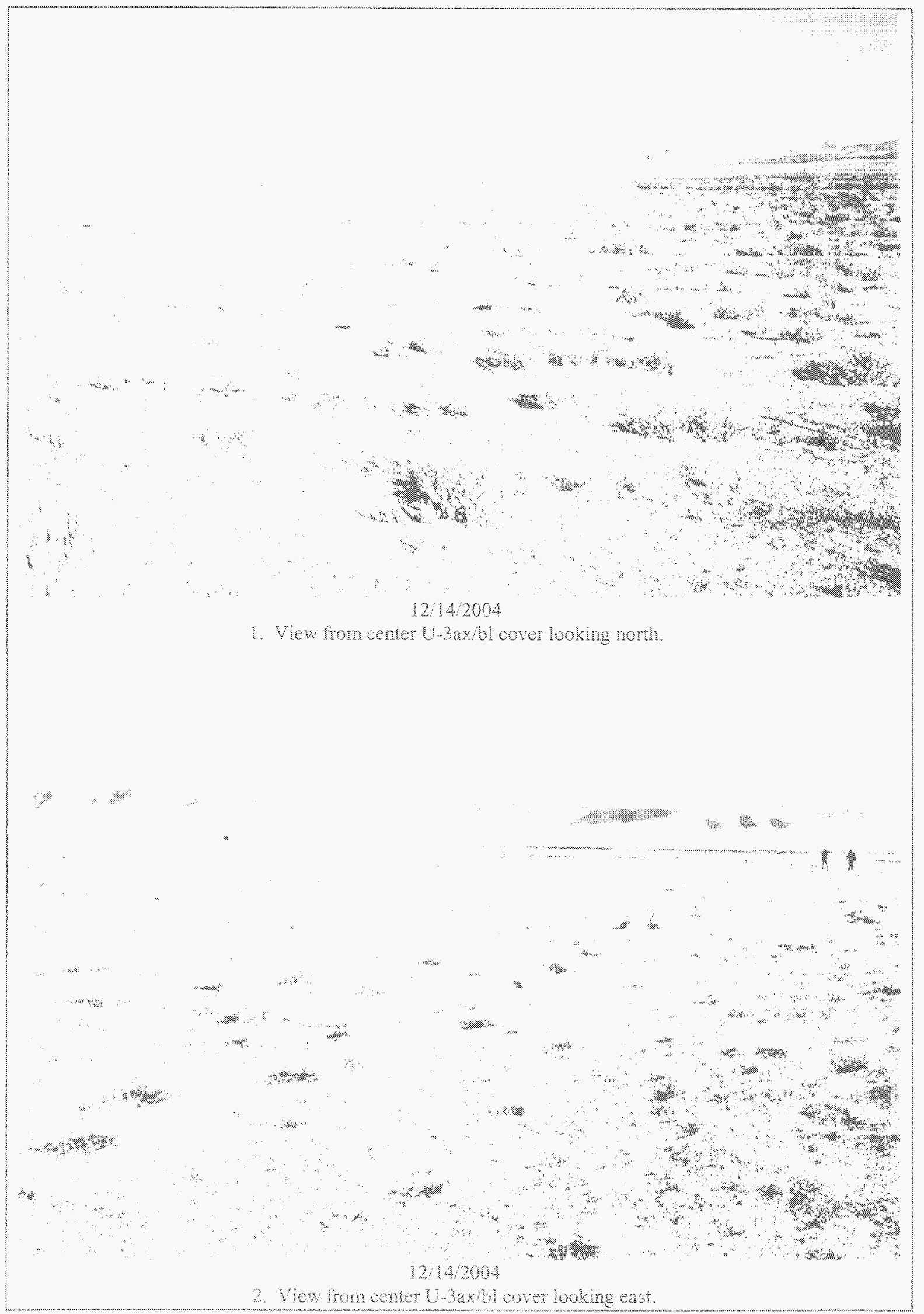


Post-Closure Report - CAU 110

Revision: 0

Date: August 2005

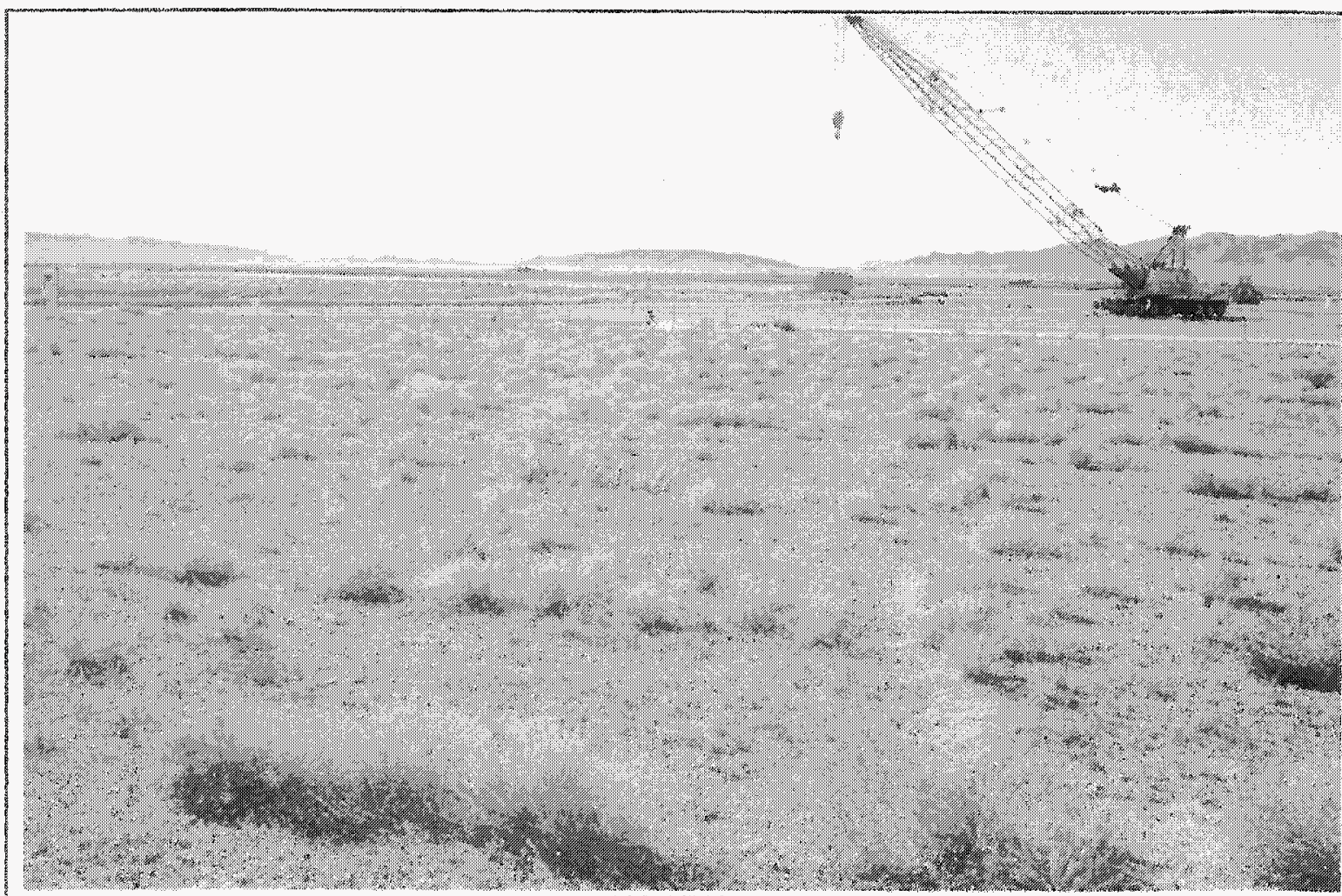

$12 / 14 / 2004$

3. View from center U-3ax/bl cover looking south,

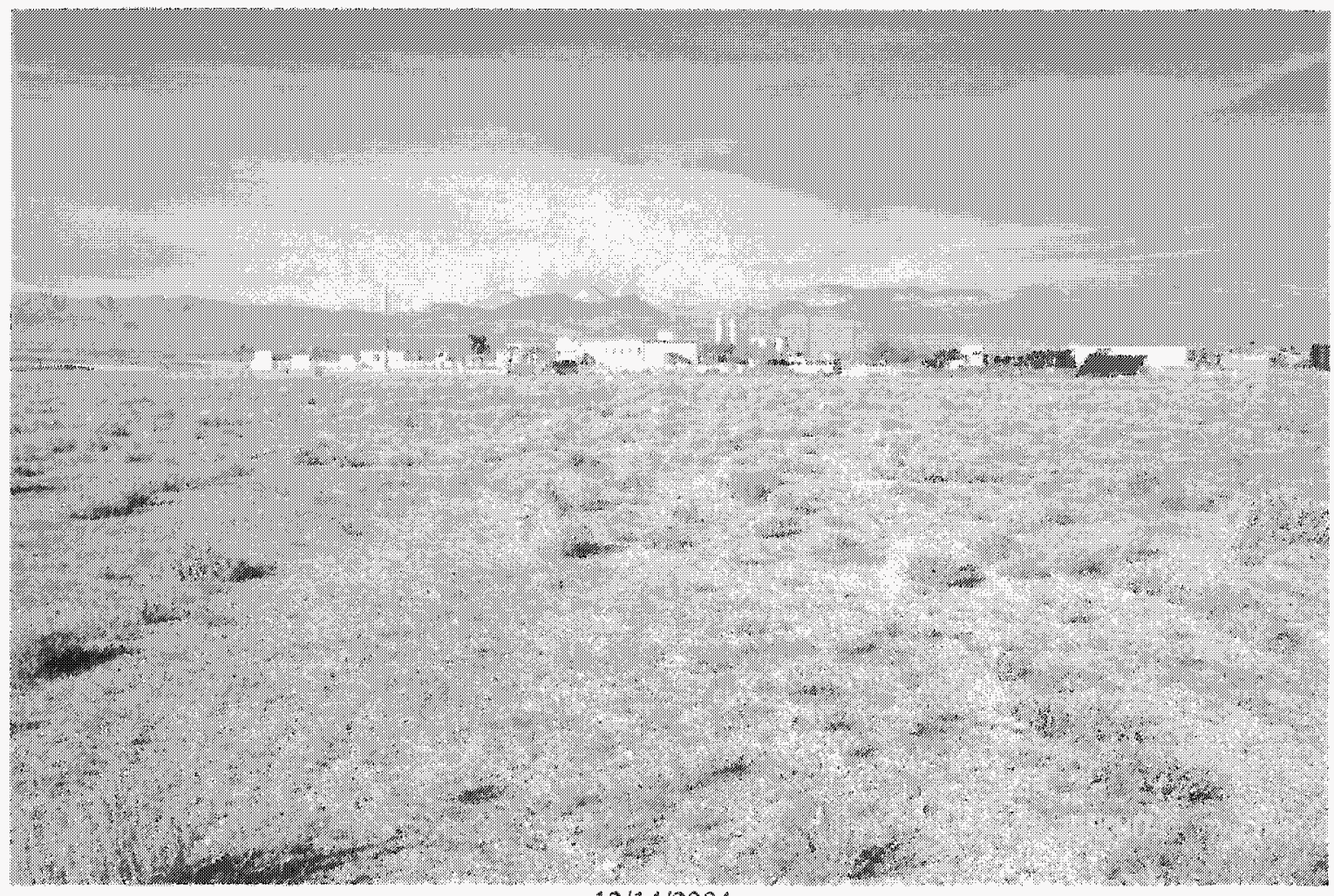

4. View from center U-3ax/bl cover looking west. 
Postchlosure Report-CAU 110

Reviston: 0

Date: August 2905

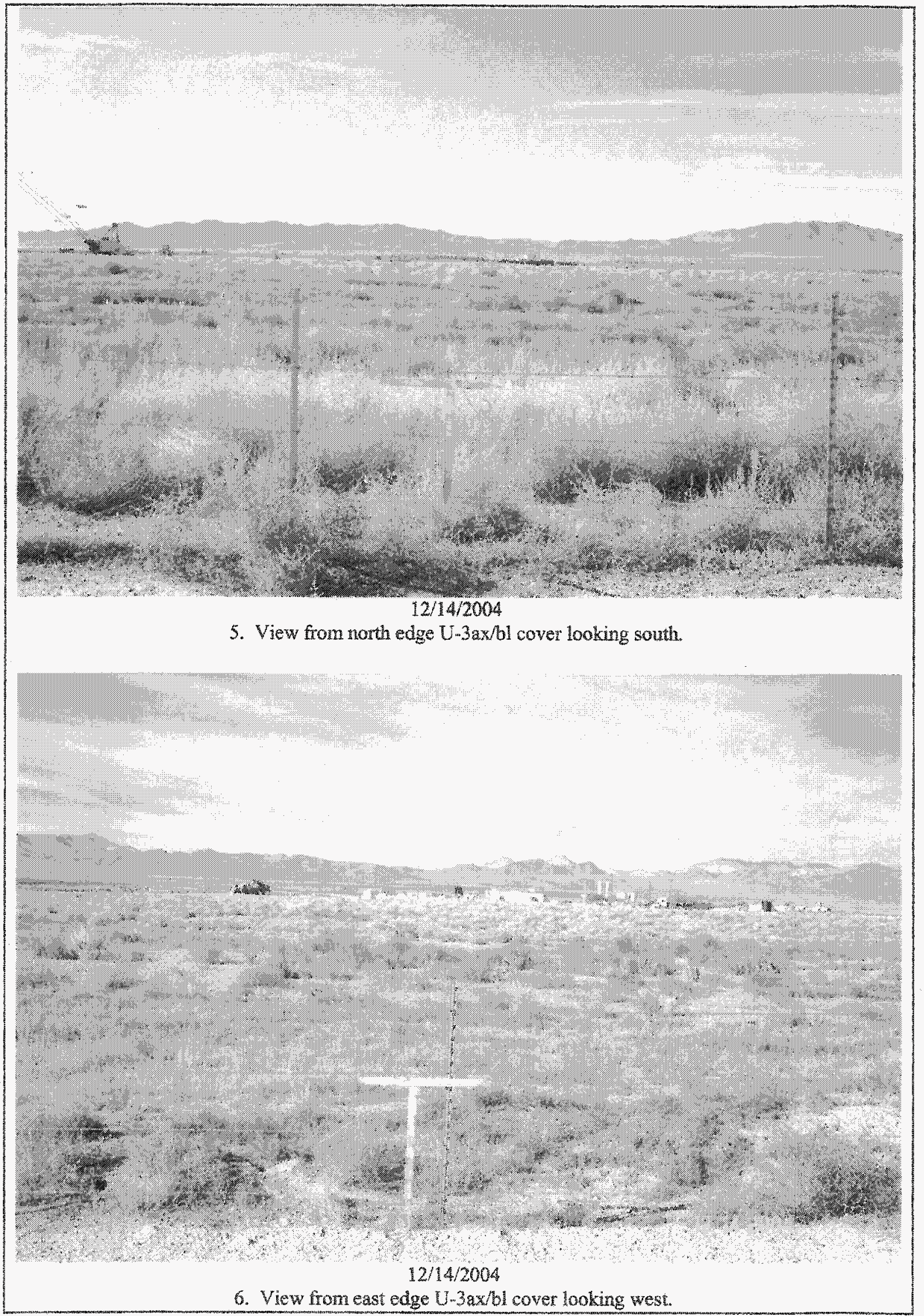




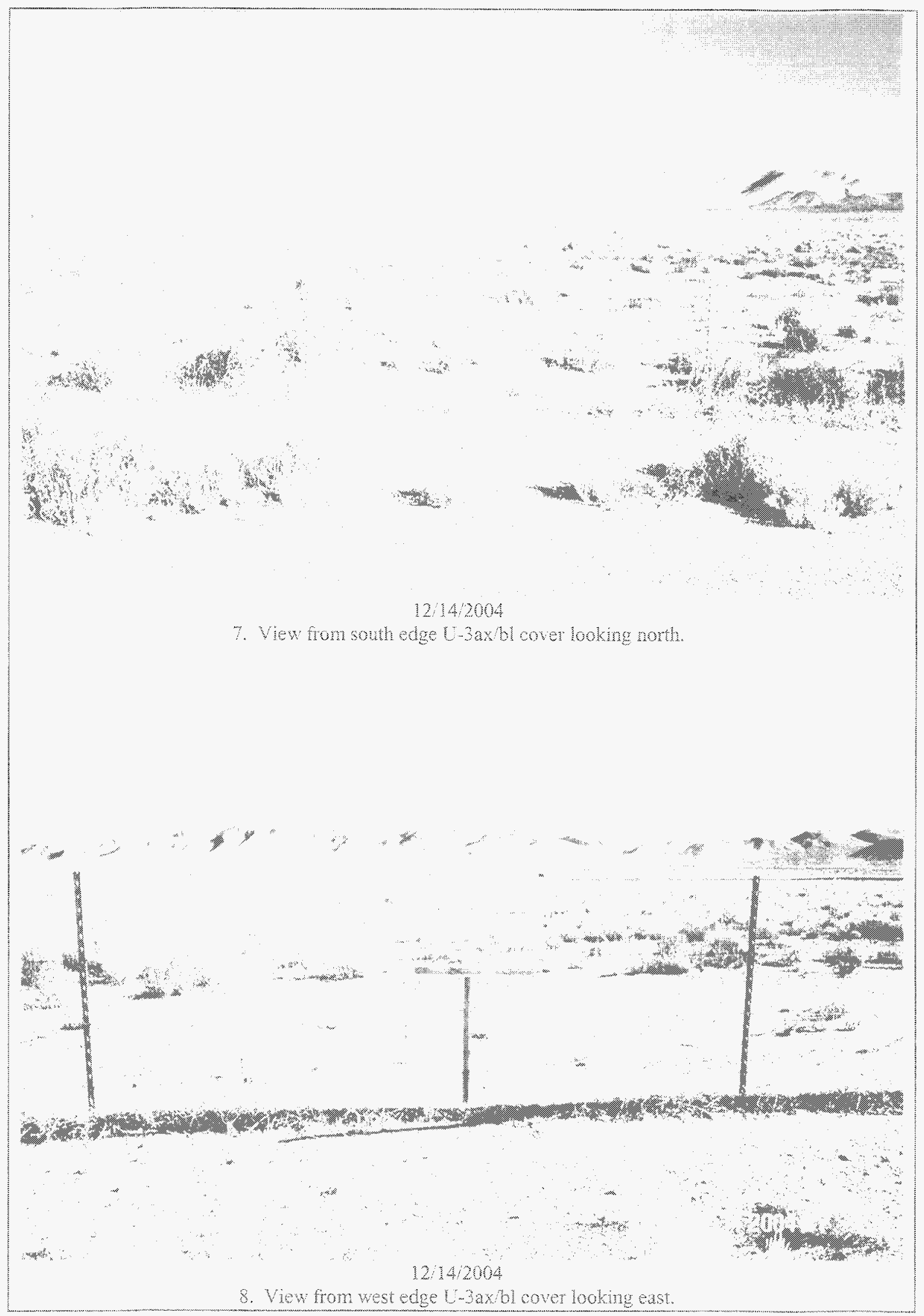




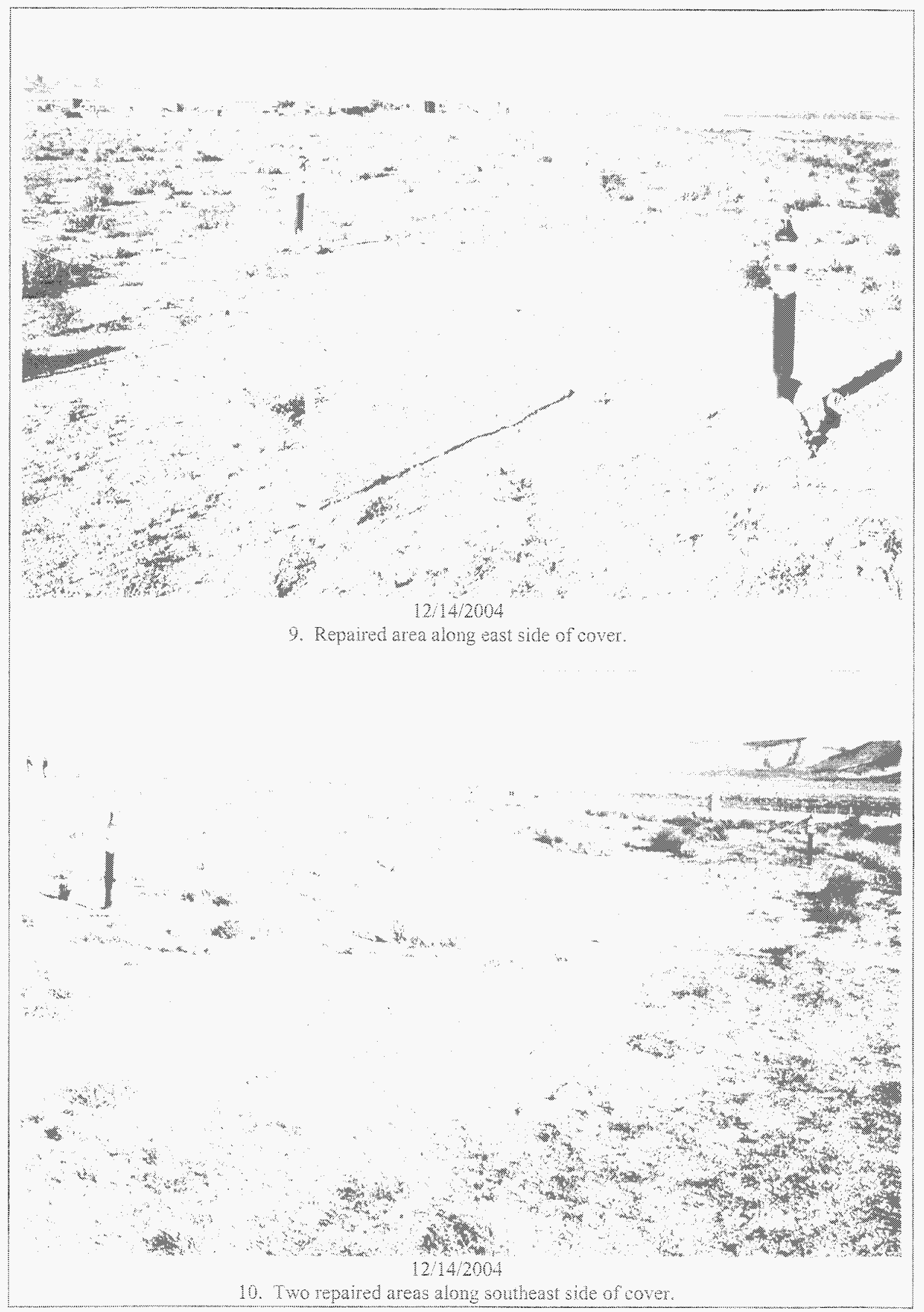


Post-Closure Revort - CAU 110

Revision: 0

Date: August 2005

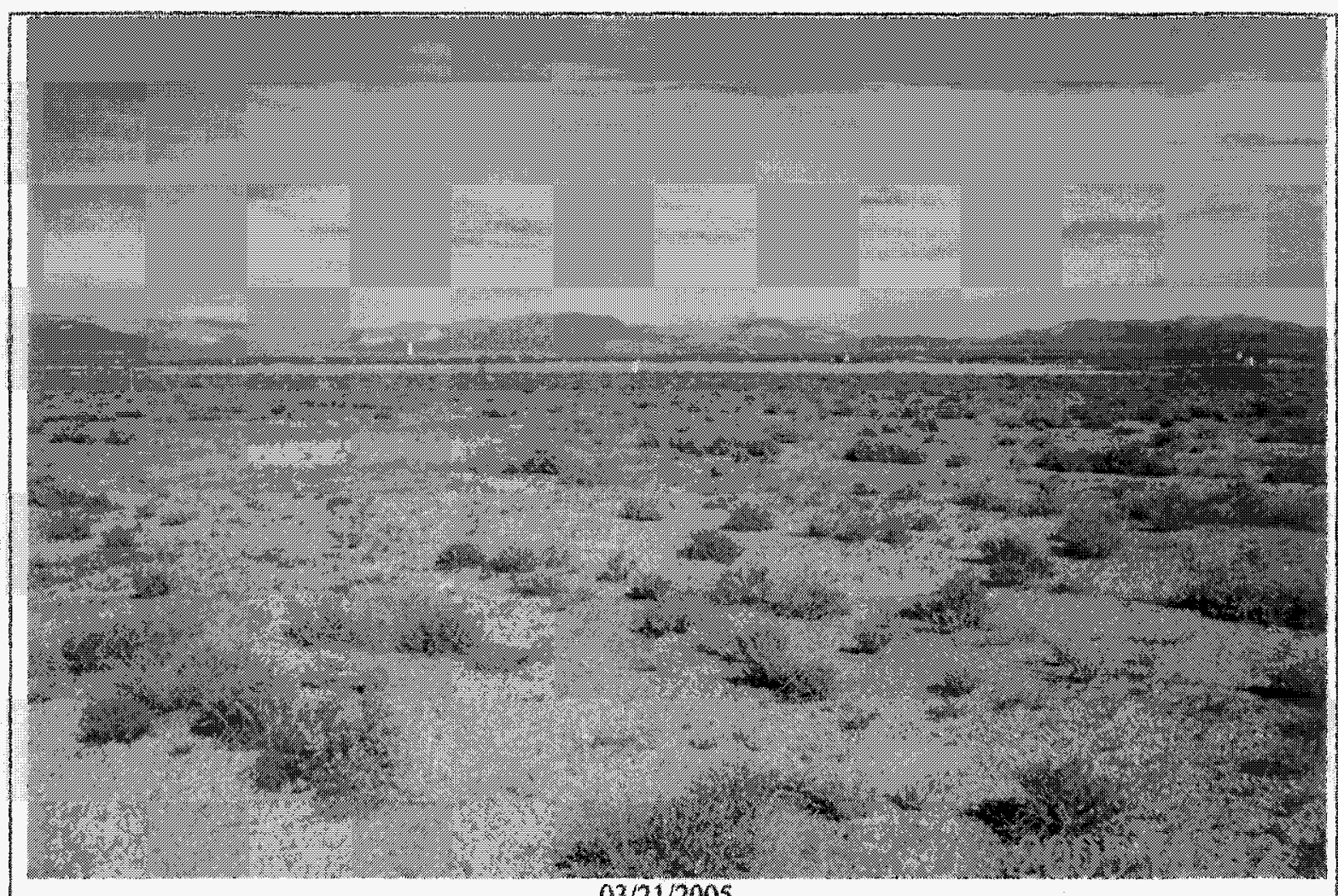

$03 / 21 / 2005$

1. View from center U-3ax/bl cover looking nomb.

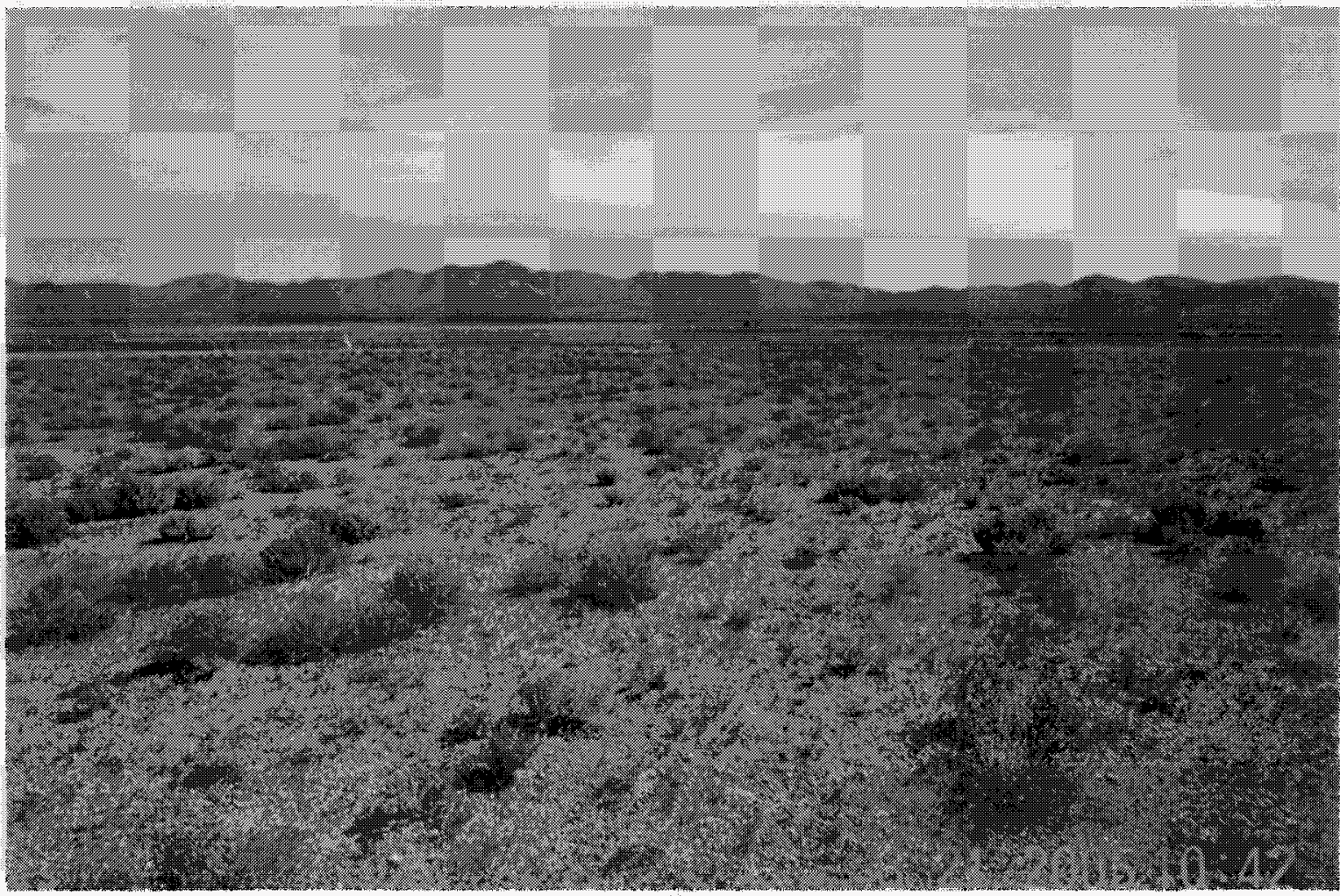

2. View from center U-3ax/bl cover looking east. 
Postolosure Report * CAU 110

Revision: 0

Date: August 2005

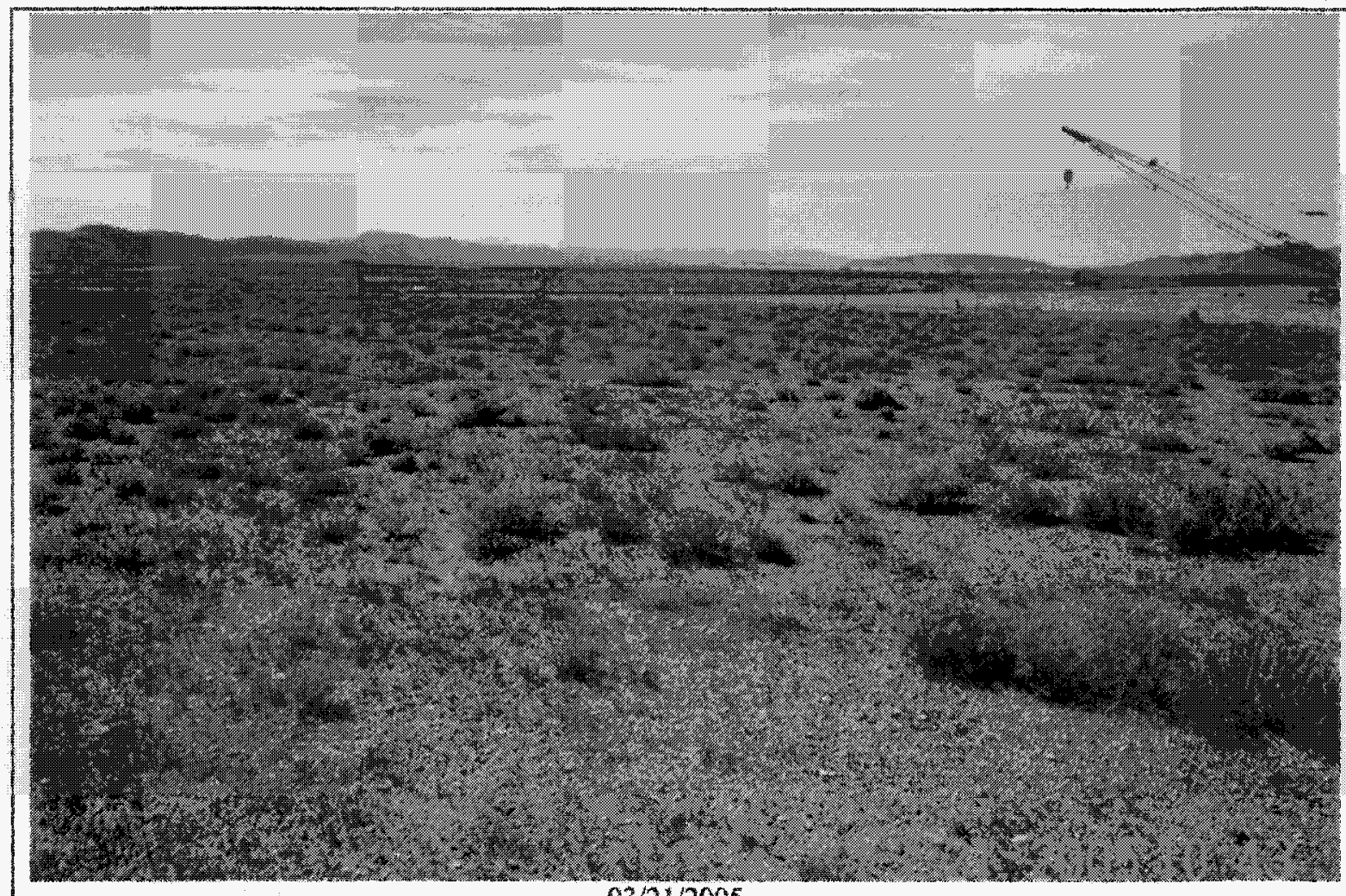

$03 / 21 / 2005$

3. View from center U-3ax/bl cover looking south.

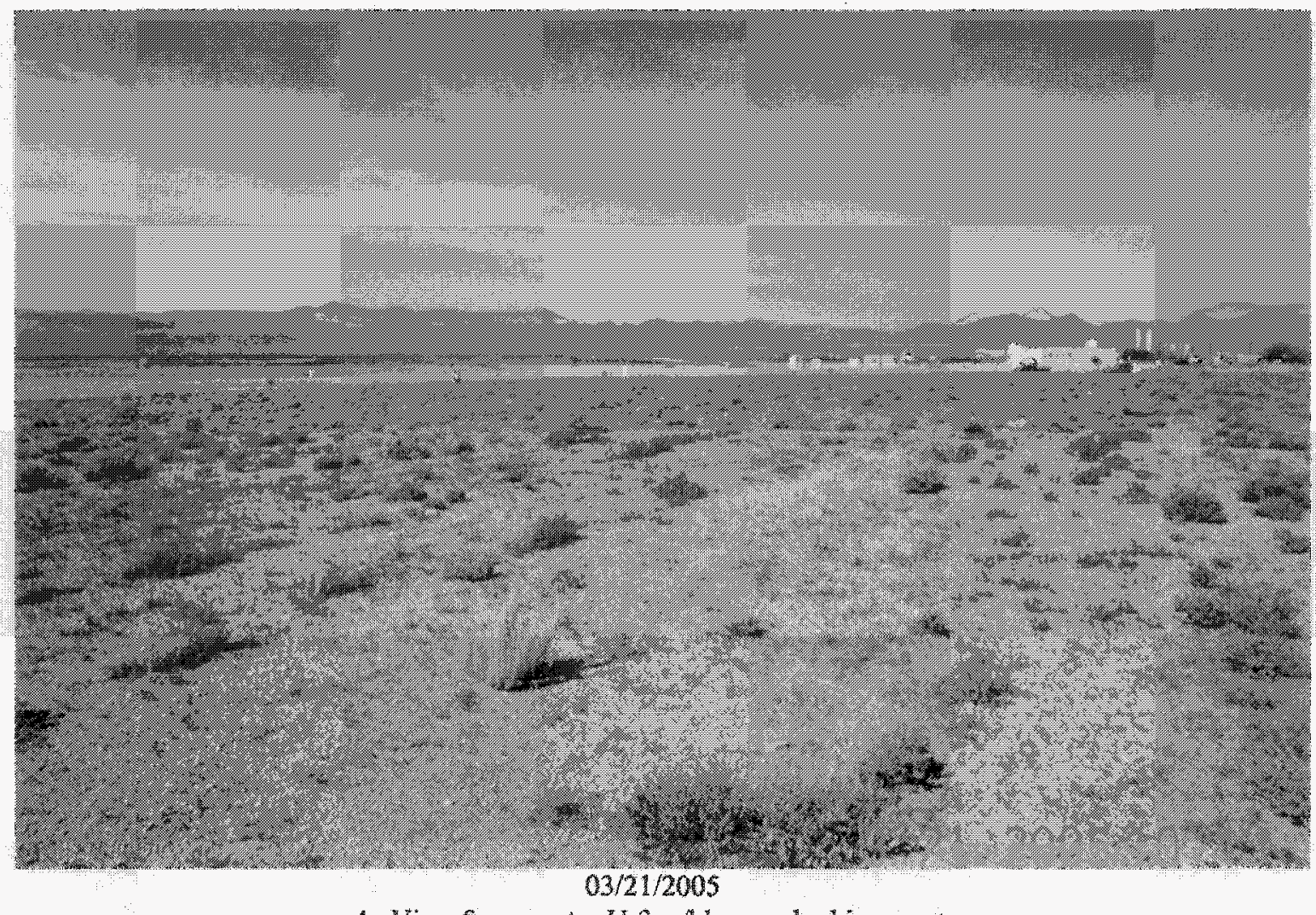

4. View from center U-3ax/bl cover looking west. 
Post-Closure Report - CAU]110

Revision: 0

Date: Auguget 2005

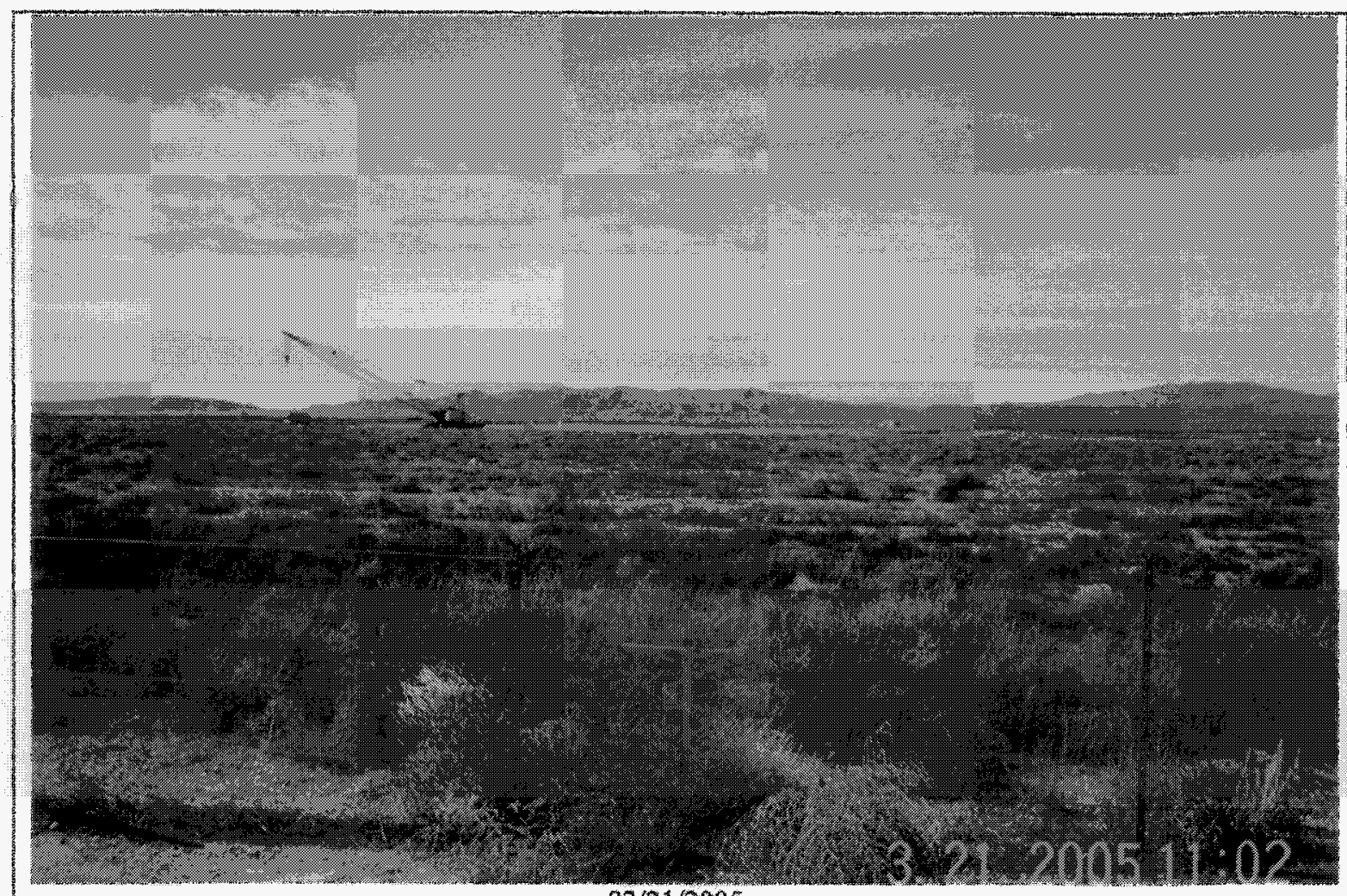

$03 / 21 / 2005$

5. View from noth edge U-3ax/bl cover looking south.






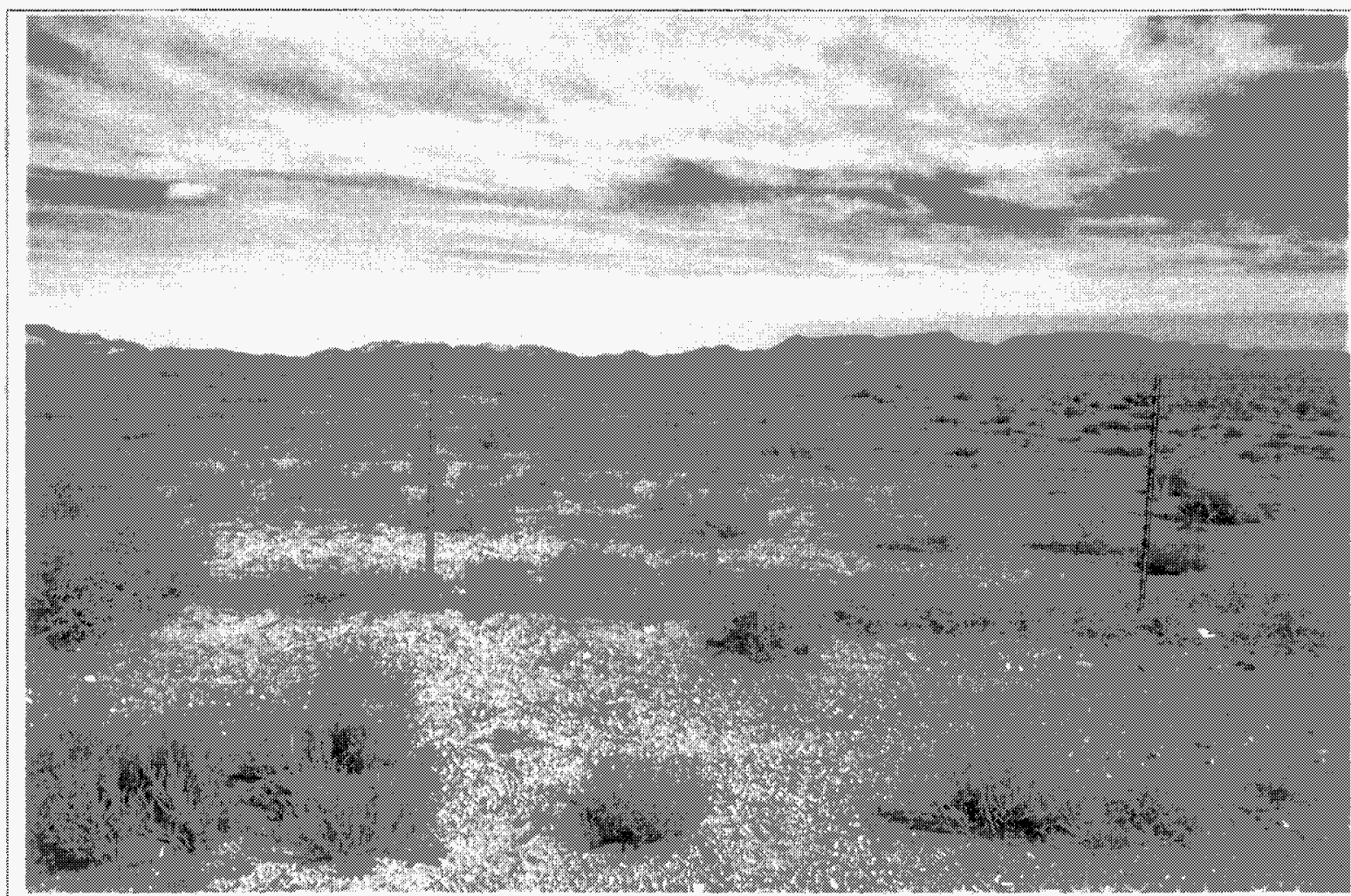
$03 / 21 / 2005$

7. View from south edge U $3 \mathrm{ax} / \mathrm{bl}$ cover looking north.
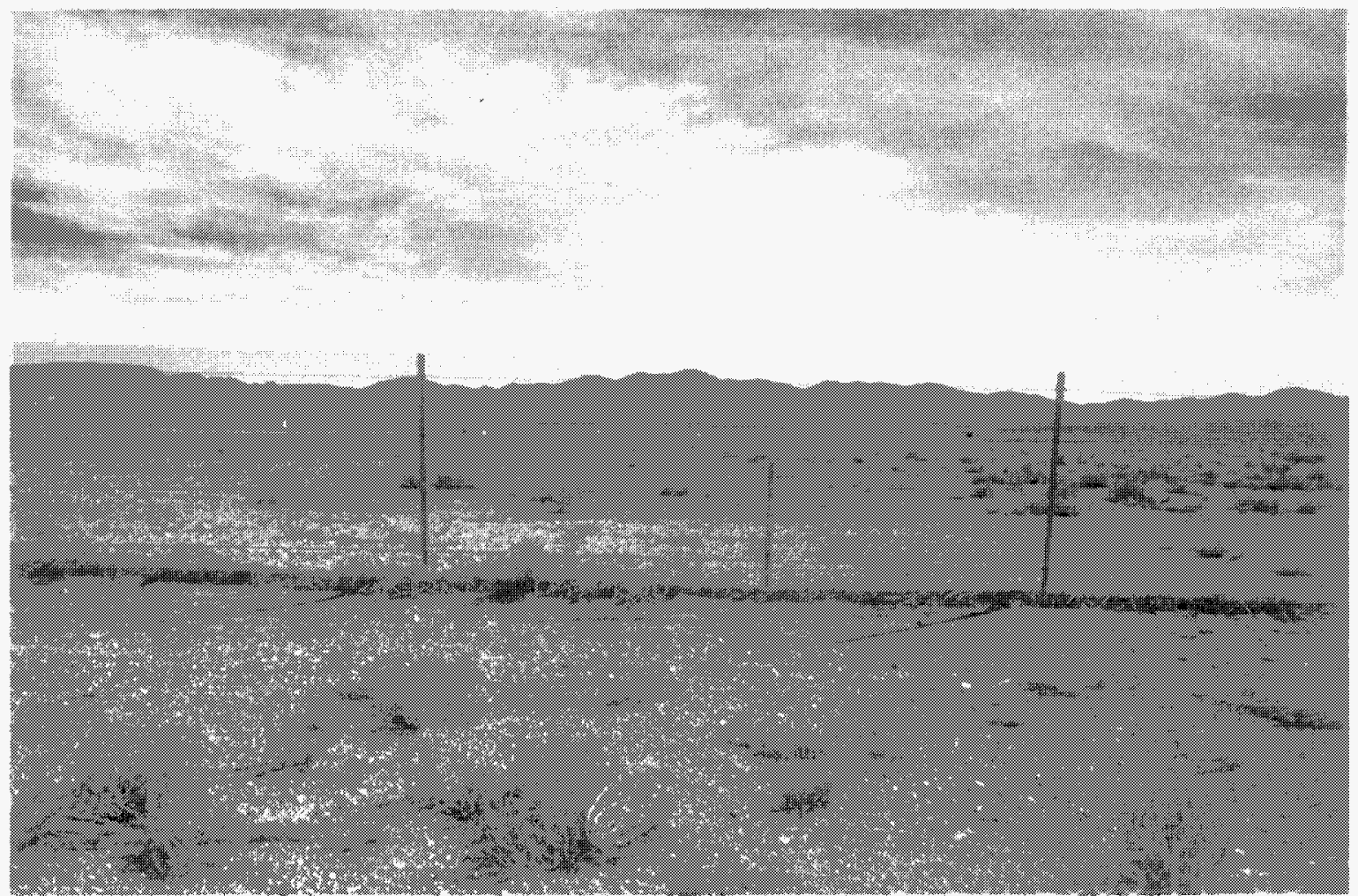

$03 / 21 / 2005$

8. Vew hom west edge U $-3 a x b$ cover looking east 
Post-Closure Report - CAU 110

Revision: 0

Date: Aupust 2005

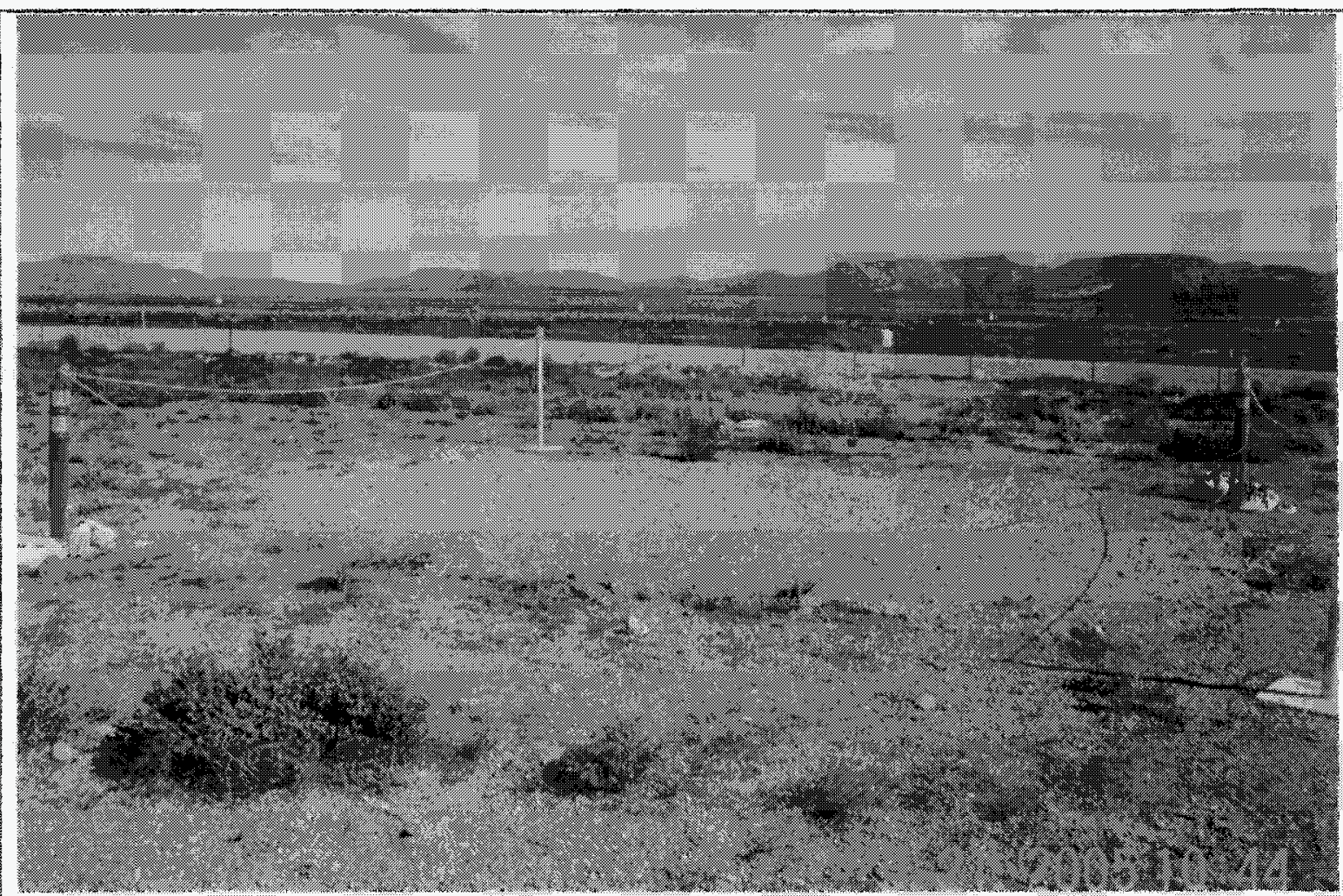

$03 / 21 / 2005$

9. Repaired area along east side of cover.

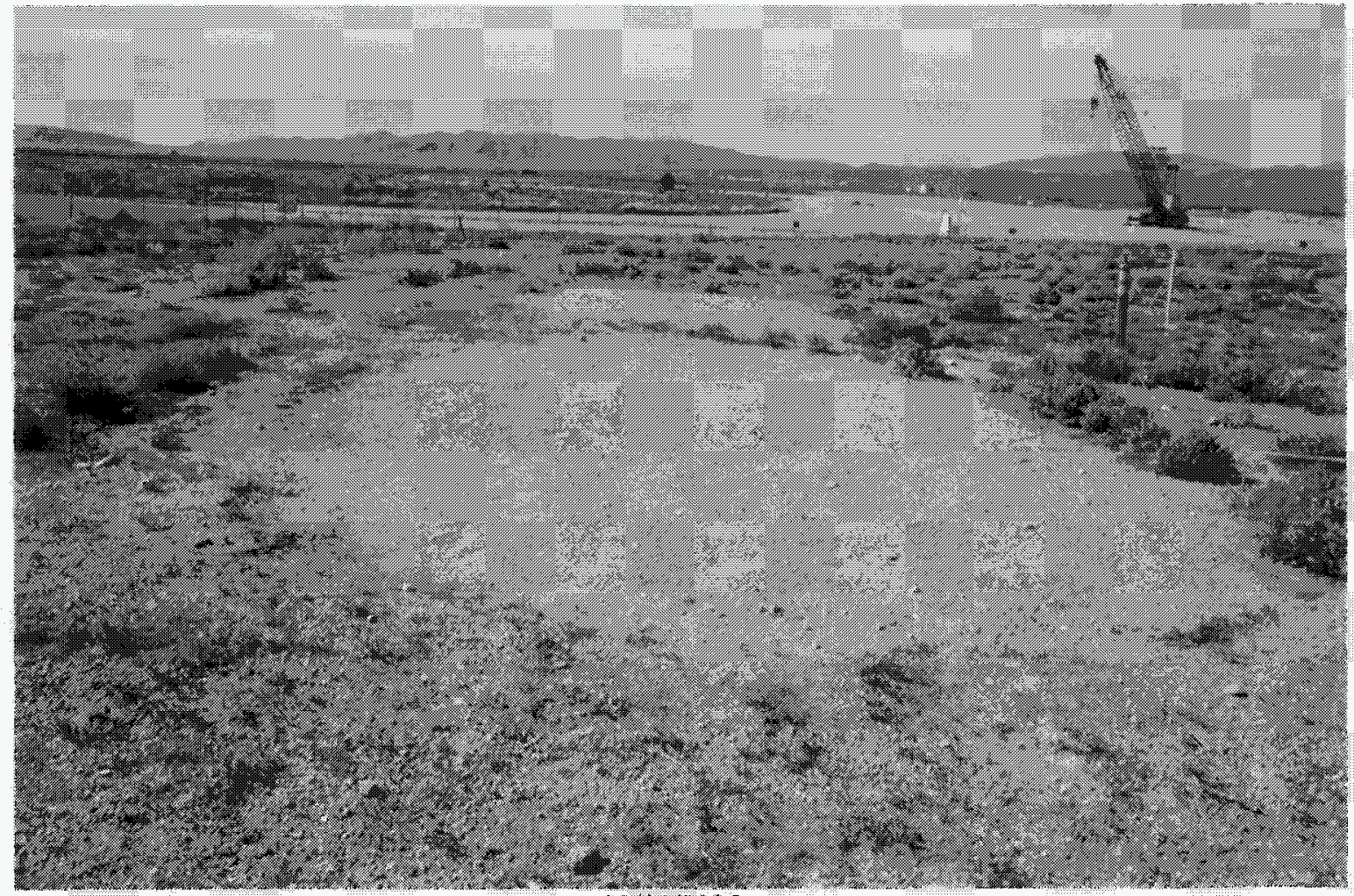

$03 / 21 / 2005$

10. Two repaired areas along southeast side of cover. 
Post-Closure Report - CAU 110

Revision: 0

Dote: August 2005

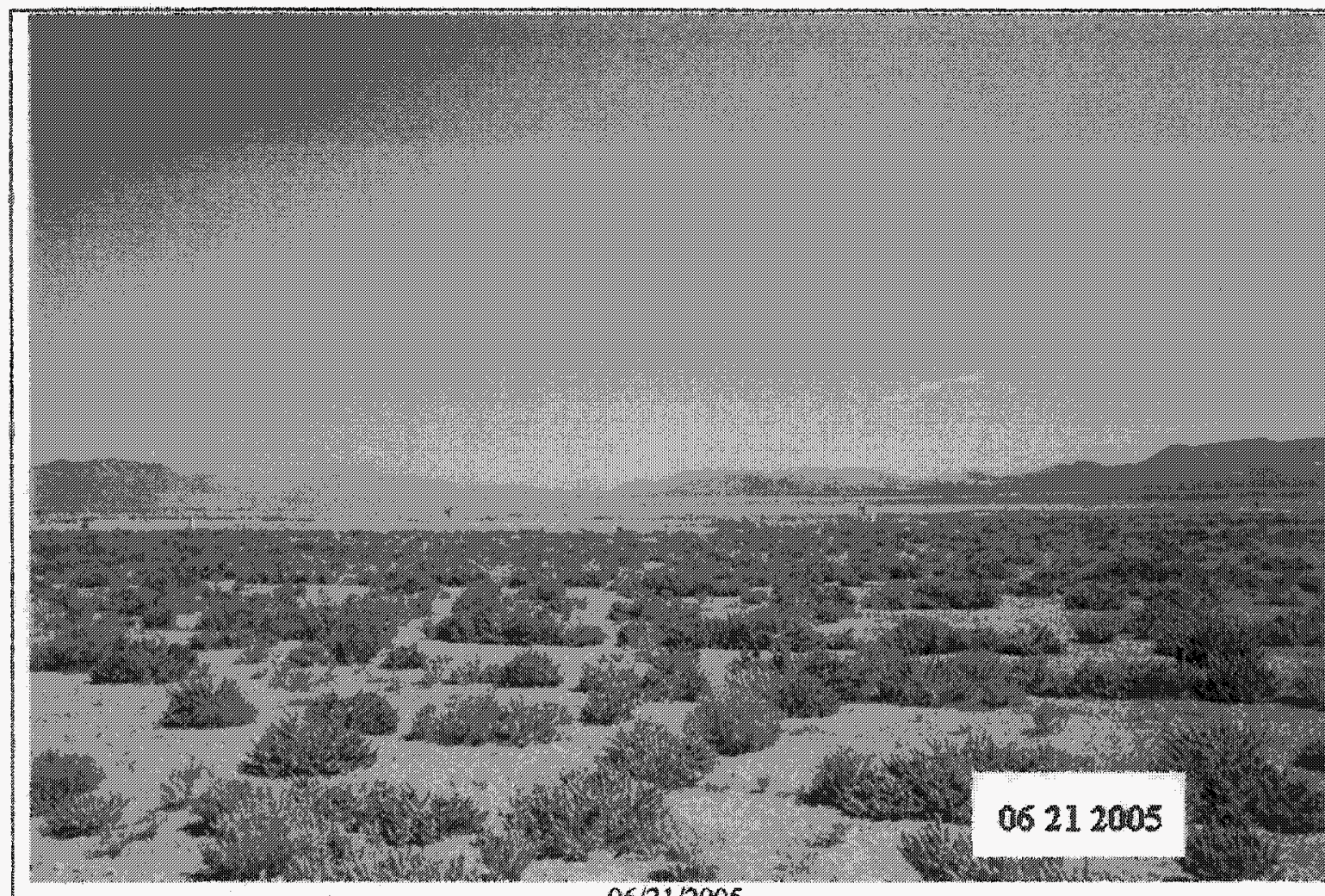

$06 / 21 / 2005$

1. View from center $U-3 \mathrm{ax} / \mathrm{bl}$ cover looking north.

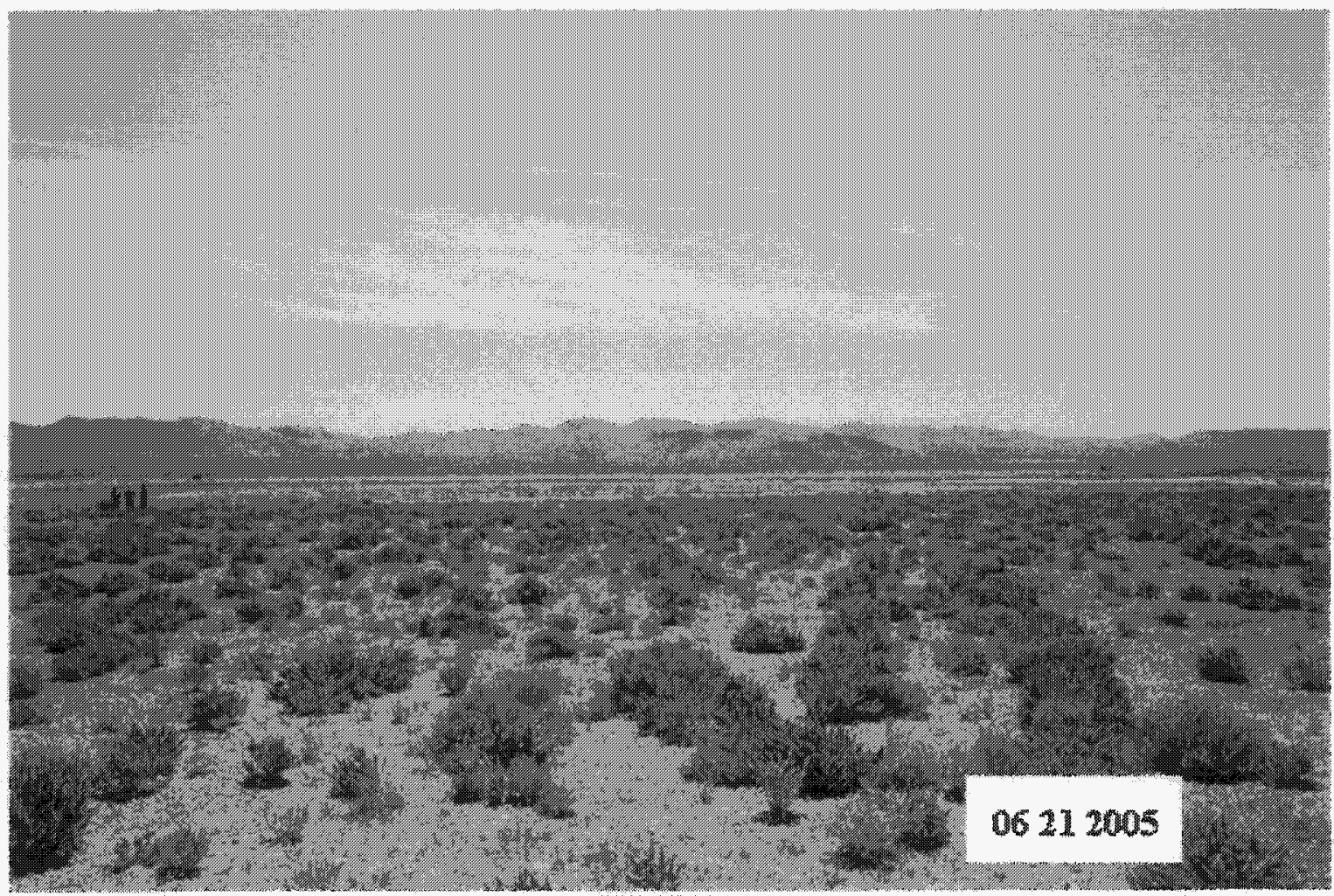

$06 / 21 / 2005$

2. View from center $U-3 a x / b 1$ cover looking east. 


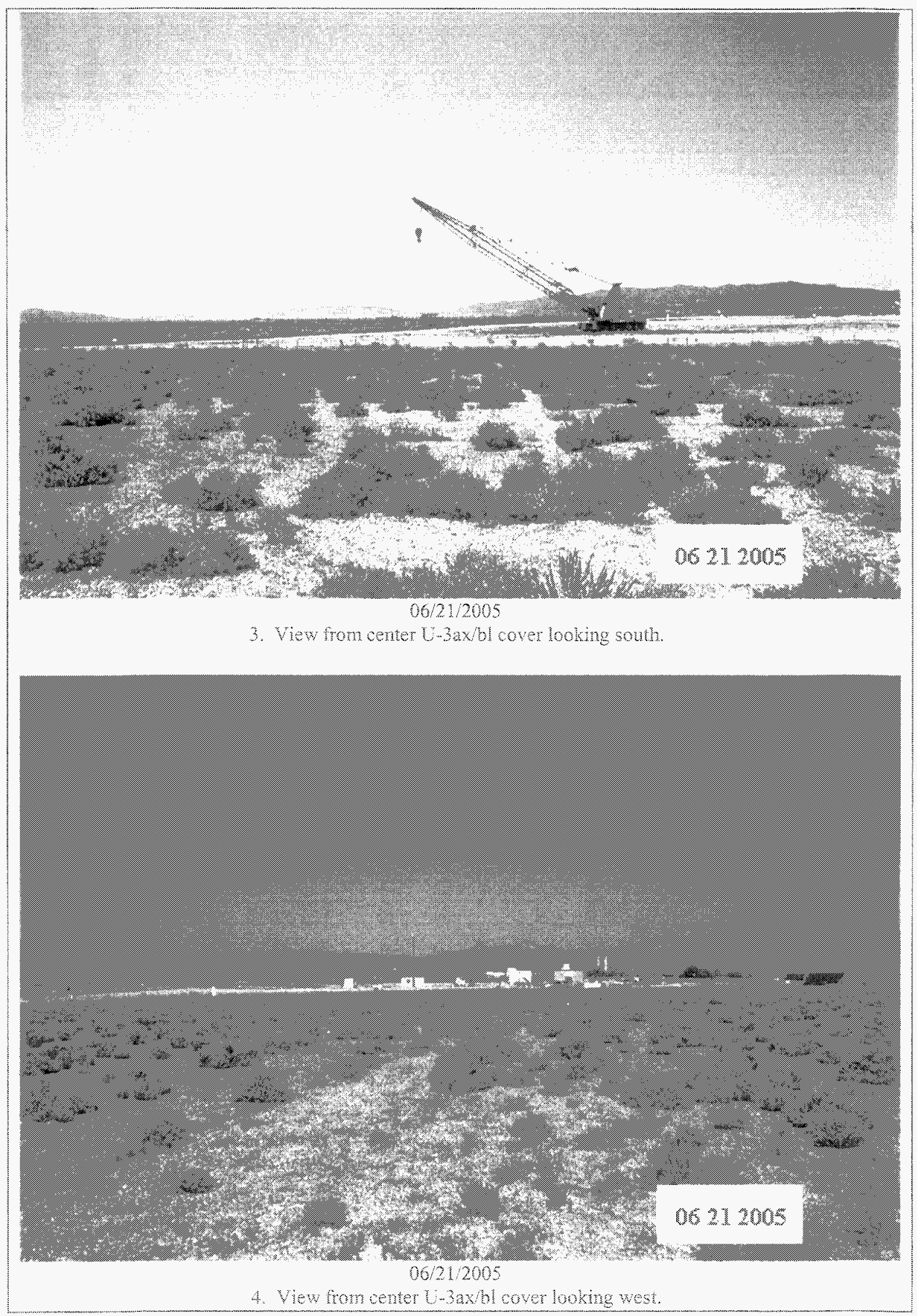




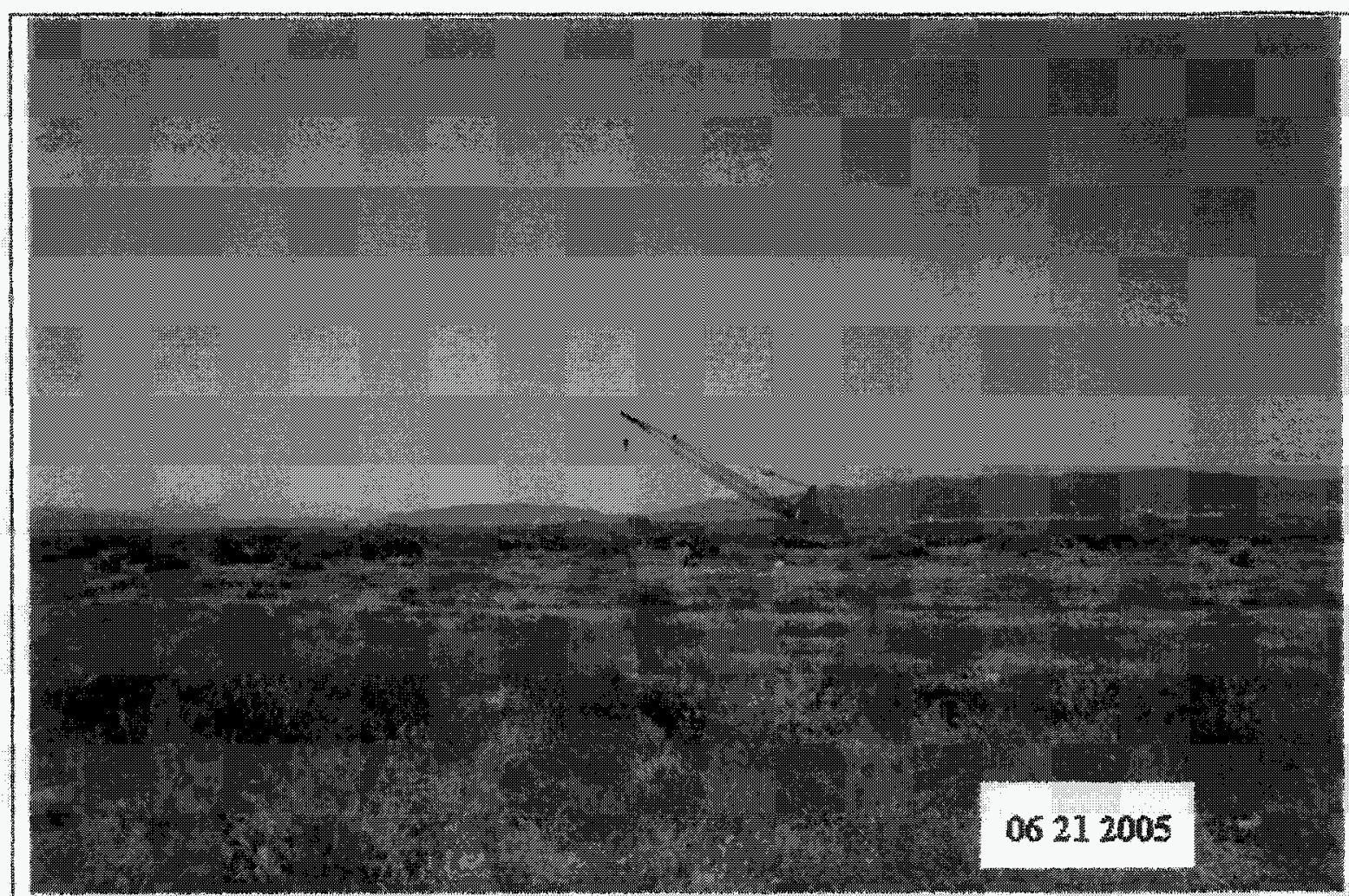

$06 / 21 / 2005$

5. View from north edge U-3ax/bl cover looking south.

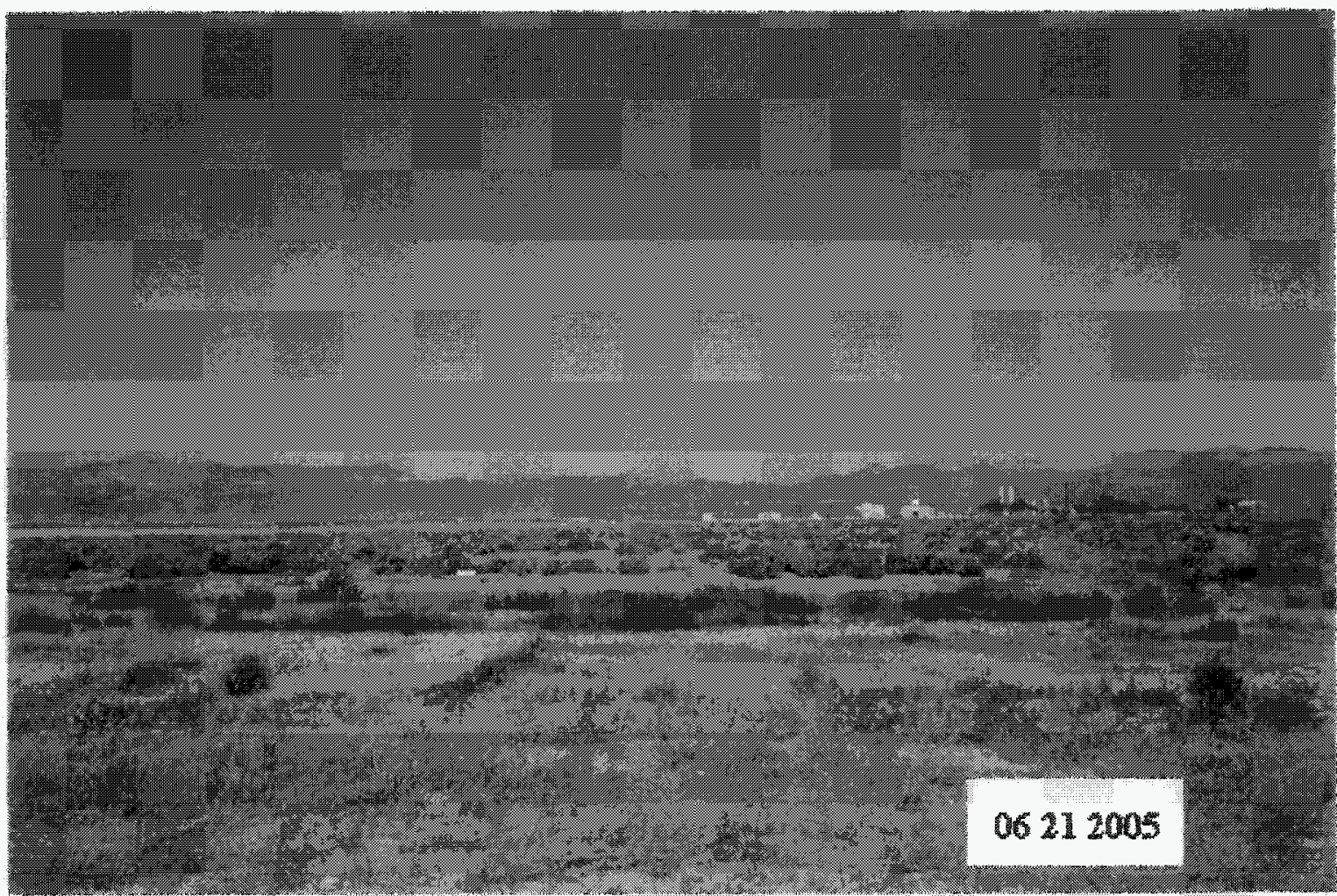




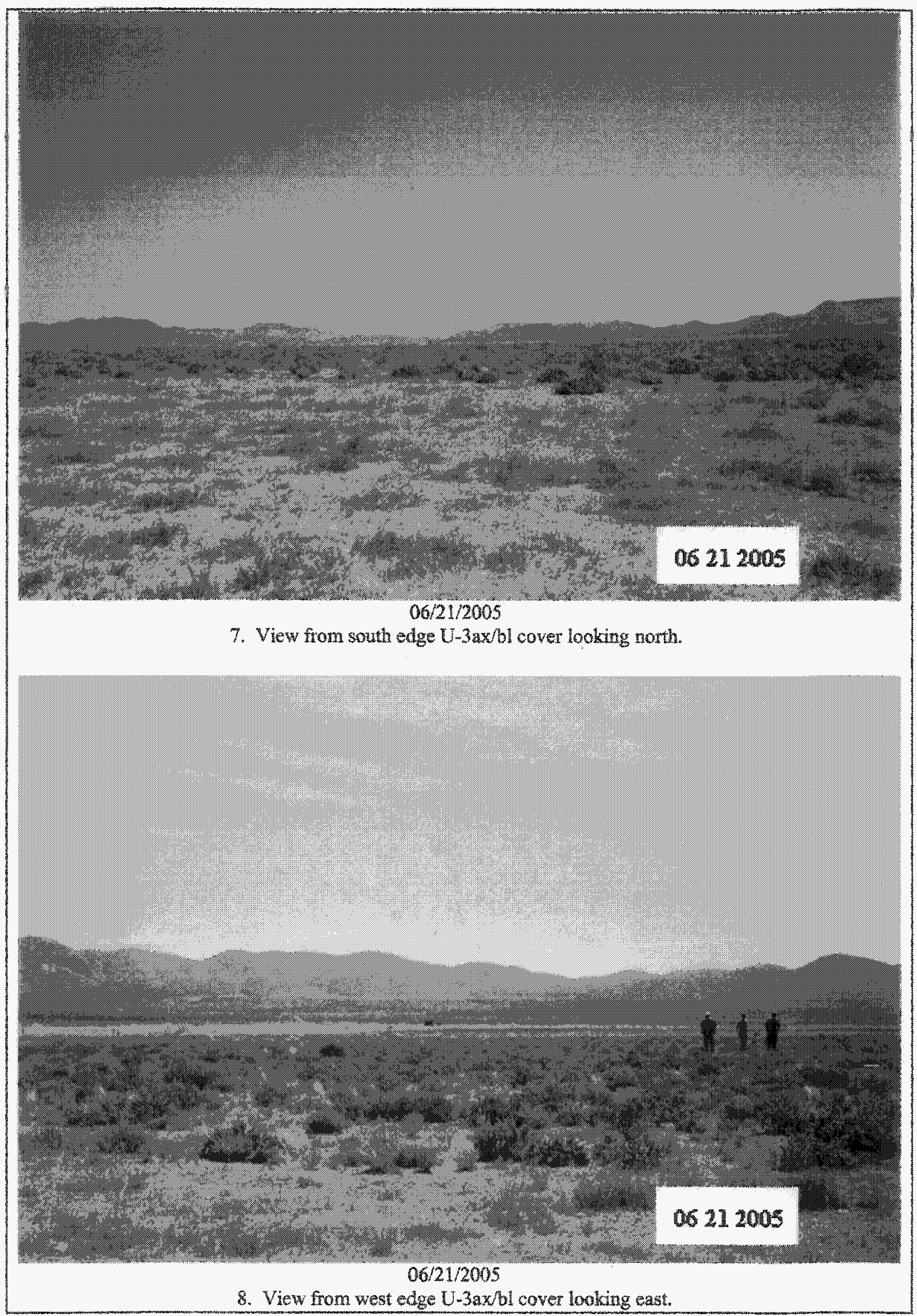


Post-Closure Report - CAU 110 
Post-Closure Report - CAU 110

Revision: 0

Date: August 2005

\section{THIS PAGE INTENTIONALLY LEFT BLANK}




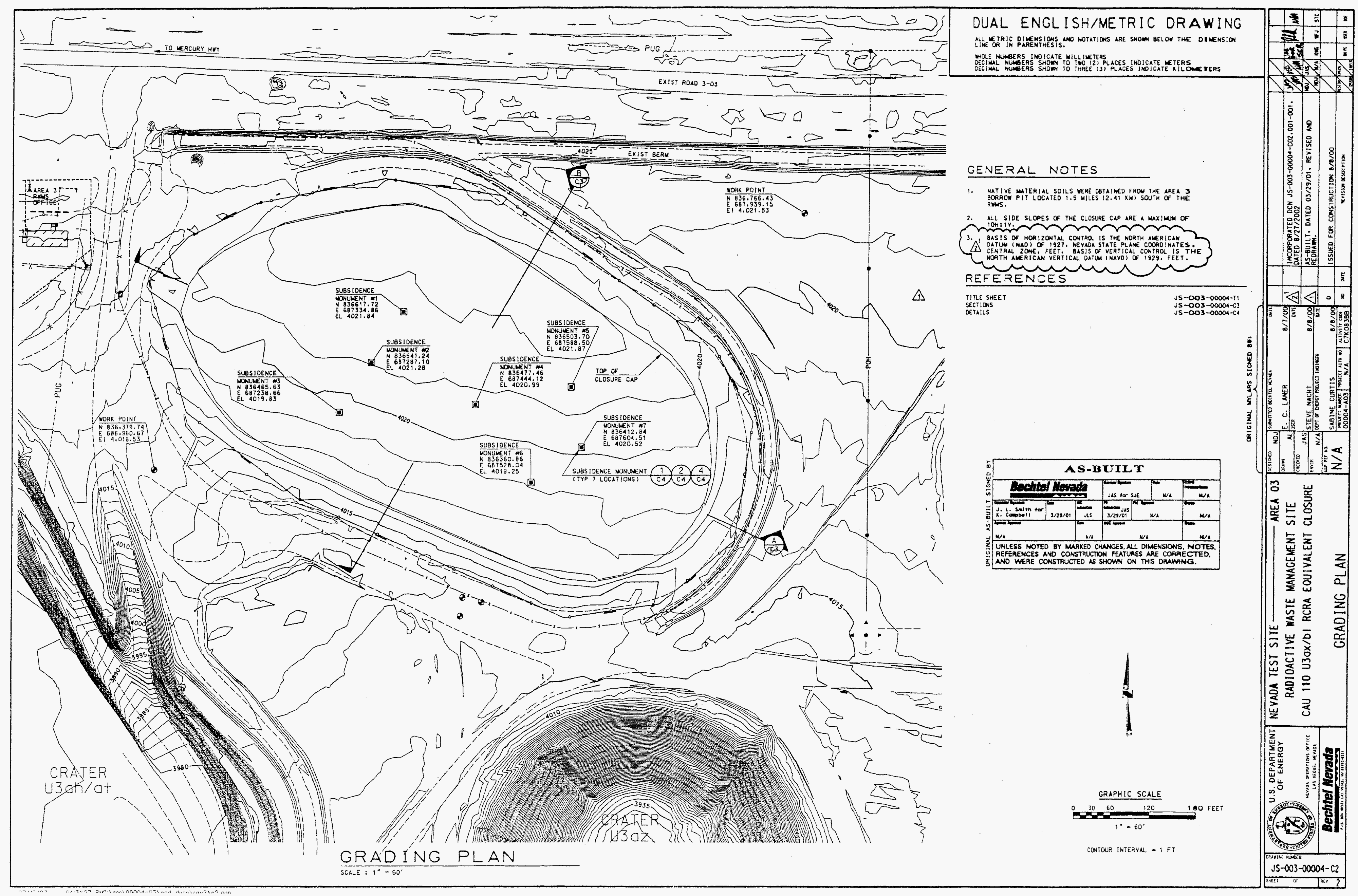


Post-Closure Report - CAU 110

Revision: 0

Date: August 2005

\section{APPENDIX C}

\section{VEGETATION MONITORING REPORT - SPRING 2005}


Post-Closure Report - CAU 110

Revision: 0

Date: August 2005

THIS PAGE INTENTIONALLY LEFT BLANK 


\section{VEGETATION MONITORING \\ CAU 110, U-3ax/bl CLOSURE COVER \\ May 2005}

\section{INTRODUCTION AND BACKGROUND}

A closure cover for the U-3ax/bl disposal unit in Area 3 of the Nevada Test Site was approved and constructed in the fall of 2000 . Immediately after the construction of the closure cover the reestablishment of a cover of native vegetation was initiated by seeding the closure cover. The slopes and the area between the cover and the fence were not seeded. Reseeding was completed in December 2000. The surface of the completed closure cover was ripped to about 6 inches to provide a suitable seedbed. The site was then seeded with a mix of nine native shrub species, two native grasses, and one native forb. All species are typically shallow rooted, which was an important factor in maintaining the integrity of the closure cover.

Natural precipitation is this region is unpredictable and meager. To maximize the potential for seed germination and plant establishment, seeding was followed with supplemental irrigation. Irrigation began the latter part of January 2001 and ended the first week of June 2001, which supplemented natural precipitation during the first growing season. The combination of natural precipitation and supplemental irrigation totaled 8.5 inches of equivalent precipitation during this period. From 1961 to 2004, annual precipitation for this area averaged 6.40 inches. In 2001, average annual precipitation at the Buster Jangle $Y$ weather station, north and west of the closure cover, was 6.1 inches, slightly below average. In 2002, only 1.5 inches of precipitation was received, and in 2003, 5.8 inches was received. Precipitation in 2004 was 10.4 inches, 4.0 inches above normal. About 4.4 inches of the 10.4 inches received in 2004 were received between October and December. During the first four months of 2005, 5.0 inches were received, all of which contributed to current year's plant growth. The 9.4 inches received since October 2004 represents about twice as much rainfall as is normally received during this same period.

The success of the reseeding effort on the closure cover has been evaluated each year since 2001 . Vegetation monitoring occurs during the period of peak vegetative production, usually between late April and mid June. Vegetation monitoring includes estimates of plant density and plant cover on the reseeded closure cover and on unseeded areas peripheral to the closure cover but still inside the fenced area.

\section{METHODS}

The same vegetation monitoring methods have been used each year since sampling began in 2001 . Field sampling was completed on May 17 this year. There are 21 100-meter transects located on the closure cover at 40-meter intervals starting at the western edge and continuing to the eastern edge. Transects are oriented in a north-south direction. Transects 1 and 21 are not sampled because of their proximity to the edge and susceptibility to disturbance. Absolute plant cover has been estimated since 2002 by life form (e.g., shrub, grass, forb) using an ocular point projection device. Five of the 19 transects are randomly selected each year. In 2005, transects 4, 5, 8, 14 and 15 were 
sampled. In addition, one transect, located along the northern edge of the closure cover in an area that was not seeded, was sampled. The ocular projection device is placed at 4-meter intervals along each transect. At each location, four ocular points are projected, and the type of cover (i.e., rock, bare ground, litter, mulch, or plant species) intercepted by the points is recorded. A total of 100 points are sampled per transect for a total of 600 points.

Plant density data are collected each year from meter square quadrats randomly located along the transects. Quadrats are randomly placed along the transects, and the number of individual plants encountered within the quadrat is counted and recorded by species. A minimum of 50 quadrats are sampled each year. In 2005, 53 quadrats on the closure cover and 10 quadrats off the closure cover, in an area not seeded, were sampled.

In April, an initiative to remove burrowing small mammals from the closure cover at $\mathrm{U}-3 \mathrm{ax} / \mathrm{bl}$ began. A total of 52 small mammal traps with trap covers were placed at strategic locations on the closure cover. An additional 44 traps were placed along the peripheral fence where there were an abundance of active small mammal burrows. Traps were placed in clusters and in close proximity to active small mammal burrows. The traps were baited with a custom mixture of bird seed and oats. Traps were opened in the evening and checked the next morning. A total of 6 trapping nights were completed in April: two sessions of three consecutive trap nights each session. Another trapping session of three consecutive nights was completed in June. During the June session, several new small mammal burrows were observed along the fenceline in the southwestern portion of the closure cover. Three additional traps were placed near these burrows increasing the number of traps on the periphery to 47.

\section{VEGETATION MONITORING RESULTS}

\section{Plant Cover}

Perennial plant cover continues to increase on the closure cover. Plant cover was 75 percent higher this year than it was last year (Table 1). The amount of cover contributed by shadscale and Nevada ephedra, the two most common perennial shrubs on the closure cover, almost doubled from 2004 to 2005. Shadscale accounts for over 90 percent of the total perennial plant cover, which it has since cover was first estimated in 2003. In response to above normal precipitation, shadscale plants were very robust and produced an abundant crop of seed (Figure 1). Although Nevada ephedra contributes less to overall perennial plant cover, it has increased significantly each year since 2003. There was a doubling of the amount of Nevada ephedra cover this year compared to last year. Winterfat, the other major component of perennial plant cover, decreased slightly, but it is still higher than it was two years ago. Winterfat plants showed remarkable growth this year (Figure 2) and most were in early seed set when sampling was conducted.

Annual plant cover was not significantly different than 2004 , when about 25 percent of total plant cover was from annuals (Table 1). In 2005, a year of abundant precipitation, annuals only make up 17 percent of the total cover. This is an indication that perennial plants are well established and are out-competing the annuals for nutrients and moisture. Annual buckwheat plants make up a third of the cover, Russian thistle another third, and the remaining third is an assortment of common native annual species. Halogeton, a weedy invader species, did not contribute to overall plant 
cover. At the lime of sampling, both halogeton and Russian thiste plants were bu young seedings. As the season progresses, these plants will muture and increase in size. However, it is noteworthy

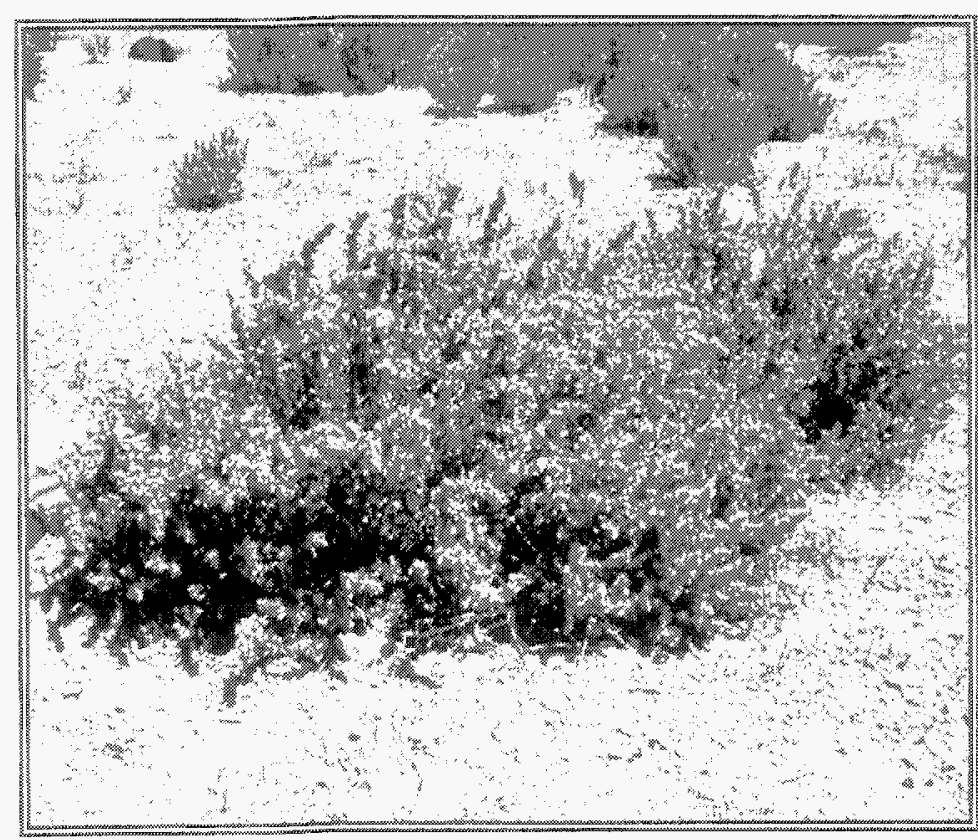

that Russim thistle cover decreased from 3 to 1.2 percent from 2004 to 2005, and halogeton has not contributed to plant cover.

Total plant cover on the edges of the closure cover, which has re-seeded naturally, was 23 percent, slighty higher than on the closure cover. A major diterence is that an of the plint cover on the un-seeded edges is from annual plants (Figure 3). Almost 80 percent of the plant cover on the unseded edges was from Russin thiste and halogeton, wo common invasive weedy species. In comparison, annual plants bardy make up 5 percent of the total plant cover on the closure cover.

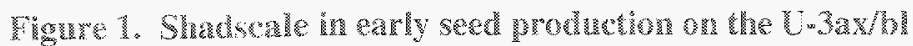
cosure cover: May 17,2005

Table 1. Averame percen phan cover on closure cover from 200 bo 2045.

Perennals

shadscale

Nevada Gundra

Wincerme

Tourwh sathush

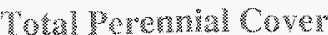

Anumals

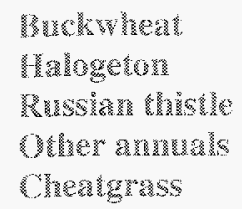

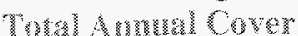

TOMA CONRK

Virter Mulch

Bare Ground

Rock

* Not roconded by spectes

wholded wh bare ground

\section{2004 2005 Unseded}

$\frac{2}{2.6}$

$(8.6)$

$(15,4)$

(0.6) (0.8)

(b)

$(0.2)$

$(0.6)$

$(0,4)$

$\underset{10}{3}$

$\frac{10.2)}{168}$

(1)

0

$\frac{1}{1}$

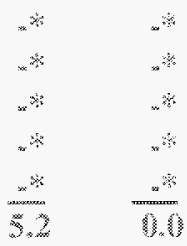

$(0.6)$

b. 2

1.2

40

(iv)

6.0

(10) 3.13

18

12.0

$(0.2)$

$\frac{11}{113}$

n

1.9

$\frac{0}{32}$

$\frac{0.2}{3.6}$

$\frac{11}{23.10}$

$\begin{array}{rr}7.8 & 6.4 \\ 43.6 & 24.1 \\ 48.6 & 69.5 \\ 4.5 & \end{array}$

3.2

12.8

20.2

$2 x^{2} \cdot 0$

28.

14.6

26.2

11.0

$30.4 \quad 38.4$

5.4

23.0

$38.4 \quad 34.2 \quad 48.2 \quad 37.0$




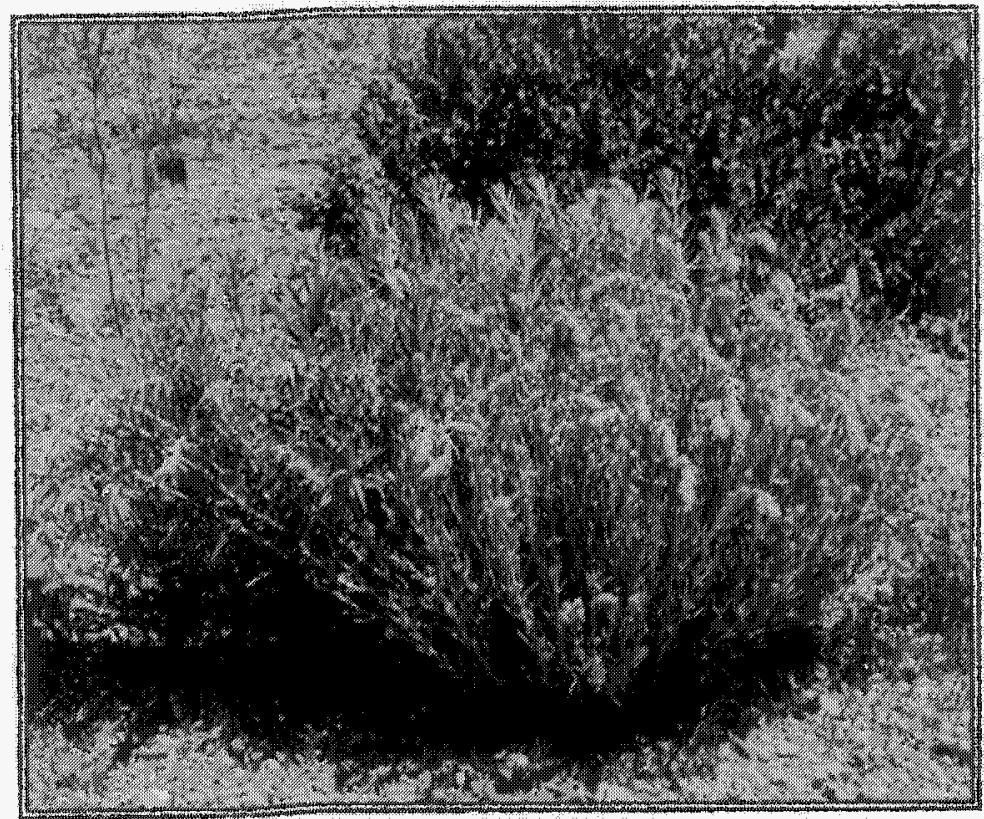

Tigure 2. Winterfat in late flowerfearly seed production on the U-3ax/bl closure cover. May 17, 2005 .
Also of note is the increase in inter on the closure cover. Litter has beclined since the site was reseded in 2001 , and bare ground/rock was approximately $60-70$ percent. This year the increase in litter and bare ground/rock is slightly over 50 percent. The higher amounts of litter the first few years were a result of the straw mulch used during the reseeding process. The mulch has degraded now and the increase in liter this year is most likely a result of increased plant growth with associated leaf drop.
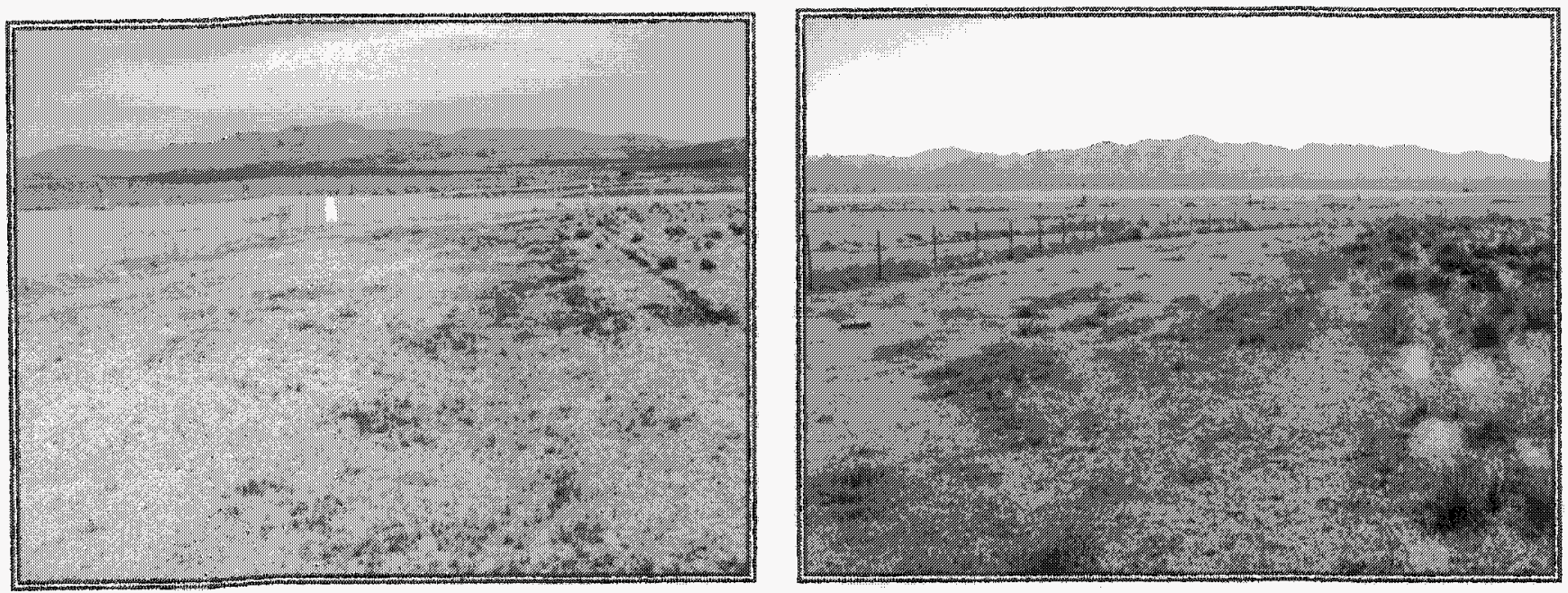

Figure 3. Invasion of weedy annual phants on the periphery of the closure cover. Photograph on left is troma 2004 and skows beginning of invasion of Ruswian thistle and halogeton. The photograph on righe was faken in 2005 and shows larger anunal plants but no perennial plants. 


\section{Ment Density}

Plant density in 2005 was 5.2 phants per square meter (w) which represents a slight increase oser. the last two yeurs (Table 2). The densty of shadscale and Nevada phedm increased shghty hom 2004 to 2005 . There was a shght tectease in densty of winterat and hdran riceyrass, but hke the moreases in phnt density, the changes may be whim sampling onor. Fven though there were insignificant deweases in density of winterfat, cover estmates for the species indicates that athough there may be fewer plans, the ones that have persisted and become estabished are larger than in previots years, thus contributing nore to plant cover.

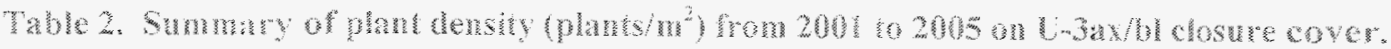

\begin{tabular}{|c|c|c|c|c|c|c|c|}
\hline \multirow{2}{*}{ SHRXE } & common Nane & HE⿰氵 & Aprien & Imese 103 & Mav & $\mathrm{Maz}$ & \multirow{2}{*}{$\frac{\text { Lusedere }}{0}$} \\
\hline & Wudsagr & 1.9 & 0 & 0 & 0 & 0.02 & \\
\hline & Ghadsente & 13.4 & ans & 2.7 & 2.3 & $2 . \$$ & p \\
\hline & 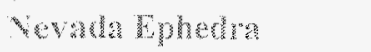 & 6.8 & 6.7 & 1.3 & 1.5 & .8 & 0 \\
\hline & Rubber kabotrum & 11.2 & $\hat{3}^{5}$ & $\theta$ & $\theta$ & O & ? \\
\hline & laredwheres & 11.3 & 4.2 & 0 & 0 & 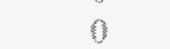 & 1 \\
\hline & mply & 1.8 & U. 1 & G. & 0.62 & 0.12 & 0 \\
\hline & Murorobsh & 9.3 & 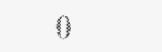 & $n$ & \} & n & 0 \\
\hline & Wintertat & 0.3 & 2.7 & 0.4 & 4.7 & 0.6 & 0 \\
\hline & Deserw thom & $n$ & 0 & 0 & 0 & 0 & 0 \\
\hline & Ponerwng Saltowsh & 0.2 & 0.1 & 0 & 0 & 0 & 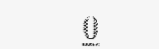 \\
\hline \multicolumn{2}{|c|}{ Toket shrubs } & 56.3 & 24.8 & $4=$ & 4.52 & 4.4 & 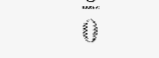 \\
\hline \multirow[t]{2}{*}{ CMASSES } & Muldrul Reograse & 5.8 & 1.3 & 6.3 & 0.6 & $n .3$ & (1) \\
\hline & sgunemon & 3.3 & 02 & 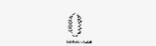 & $\underline{0}$ & 0. & 1 \\
\hline \multicolumn{2}{|c|}{ wotul cinsses } & $\overline{9.1}$ & 1,5 & 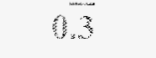 & $\overline{0.4}$ & $\overline{6.4}$ & 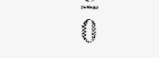 \\
\hline Tolss & Gobemallow & 4,1 & 0 & $y$ & 0 & 0 & U \\
\hline \multicolumn{8}{|c|}{ TOTALPRMMHA } \\
\hline \multicolumn{2}{|c|}{ WANT DESTTY } & $6.5,1$ & 26,3 & 4.8 & $\sqrt{92}$ & 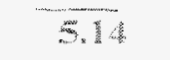 & 0 \\
\hline \multirow[t]{5}{*}{ MNUN紊意S } & Wrokwhen & ж & $\ldots$ & 15. & $\because .8$ & $3,3,7$ & $3 \%$ \\
\hline & Wogcton & $\ldots$ & - & 0.2 & 3,9 & 12.5 & 22.6 \\
\hline & Russianthiste & - & .. & 3.4 & $7 \% .0$ & $7 \mathrm{O}_{3}$ & 182.5 \\
\hline & 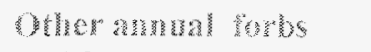 & . & $\therefore$ & his & 0.4 & 2.0 & b.5 \\
\hline & 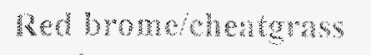 & & $\cdots$ & h. & 0,5 & 19 & $\underline{1.4}$ \\
\hline \multicolumn{2}{|c|}{ Potolnhunds } & & & $\sqrt{9.6}$ & 80.9 & $1 0 \longdiv { 1 0 4 }$ & $2 4 \longdiv { 1 9 }$ \\
\hline \multicolumn{2}{|c|}{ TOALPMAN DESTTY } & 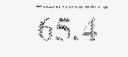 & 263 & 24.4 & 8.82 & $10 \times 64$ & 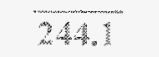 \\
\hline \multicolumn{2}{|c|}{ 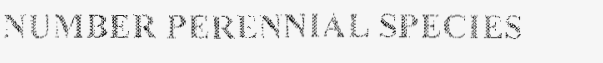 } & 11 & 9 & 6 & 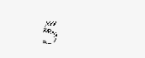 & 7 & 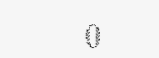 \\
\hline \multicolumn{2}{|c|}{ WUMPRKANEULSPECHEO } & 0 & 0 & 6 & 5 & 3 & $\%$ \\
\hline
\end{tabular}


Numerous sedlings were observed this year, whon would be expected with the favoble amount of precipitation. Of note were seedings of reegrass and budsage. The seed for the vicegrass seedlings could have come from plants that have estabished onsie and ser seed last year. Budsage. however, has not been observed on the closure cover since the first year, and seed most likely came from residual seed in the sol.

The density of shadscale, the most abundant spectes on the closure cover, appears to have stabihed as has the density of winterfat and Indian ricegrass. Density for these thee species has not differed significanty over the last three years. The devity of Nevada ephedra has increased by about 15 percent each year for the last three years.

Spiny hopsage has been present onste since 2001 . This year, lke last year, only one plant was chcomtered. Several other individual spiny hopsage were observed on the closure cover, but hey are uncommon. The other species of note is squmeltail. It has not been observed on the closure cover since 2002. A few indiduals, manly seedings, were observed this year. It will be imponant that the new plants establish, mature and set seed in order for this species to persist on the closure cover.

As observed in previous years, several individual fourwing salbush, although not included in the original seed mix, have established on the closure cover. This species is not a preterred species on the closure cover because of is deep rooting system. Fourwing salbush will be nonitored closely to detect increases in density. The concem is buffered by the fact hat at other revegetation sites on the NTS it has ben observed that fourwing salbush does not persist as well over ime as do oher native specics. With the the presence of this species may not be an issue.

In 2005 , amual plant densily was the highest it has ever been. The 100 plants $/ \mathrm{m}^{2}$ this year represents a 20 percent increase over last year and a fwe fold increase over anmul density estimates in 2003. The species with the most significant increases were buck wheat, halogeton and cheatgrass (Table 2). Interestingly, the density of Russian thiste was slighty lower this year than last year. As was common throughou much of the region this spring, there was an abundance of native ammal forbs. Common natve willowers observed on the closure cover this year included smooth desertandehon, dustymaden. blazingstar, Nevada cateye, bristy fiddeneck, and all nublemustard (Figure 4).

\section{Mand Diwesivy}

During the lins few growng seasons after reseding. there were about ten difterent perennial plant species on the site. By the third growing season and the third year of below nomal precipiation, budsage, rubbet rabbitbush, smubby buckwheat, and squireltail grass, once present, were absent. The number of individual plants of the other species dechned drasticaly durng this period, but the native spectes were able to persist until more fawrable growing conditions occured in 2004 . This year, budsage and squirelal grass, two species not found on the closure cover since 2002, were found on the closure cover (Table 2 ).

The number of anual species more than doubled from 2004 to 2005 (Table 2). This increase is a result of sufficient moisture and the migration of seed of both native and non-native amual plants onto the closure cover. With the addition of about a dozen natve armual species, the closure cover 
vegetation appears much like native plant communites with a mix of perennial shubs and grasses, and native annual plants (Figure 4).

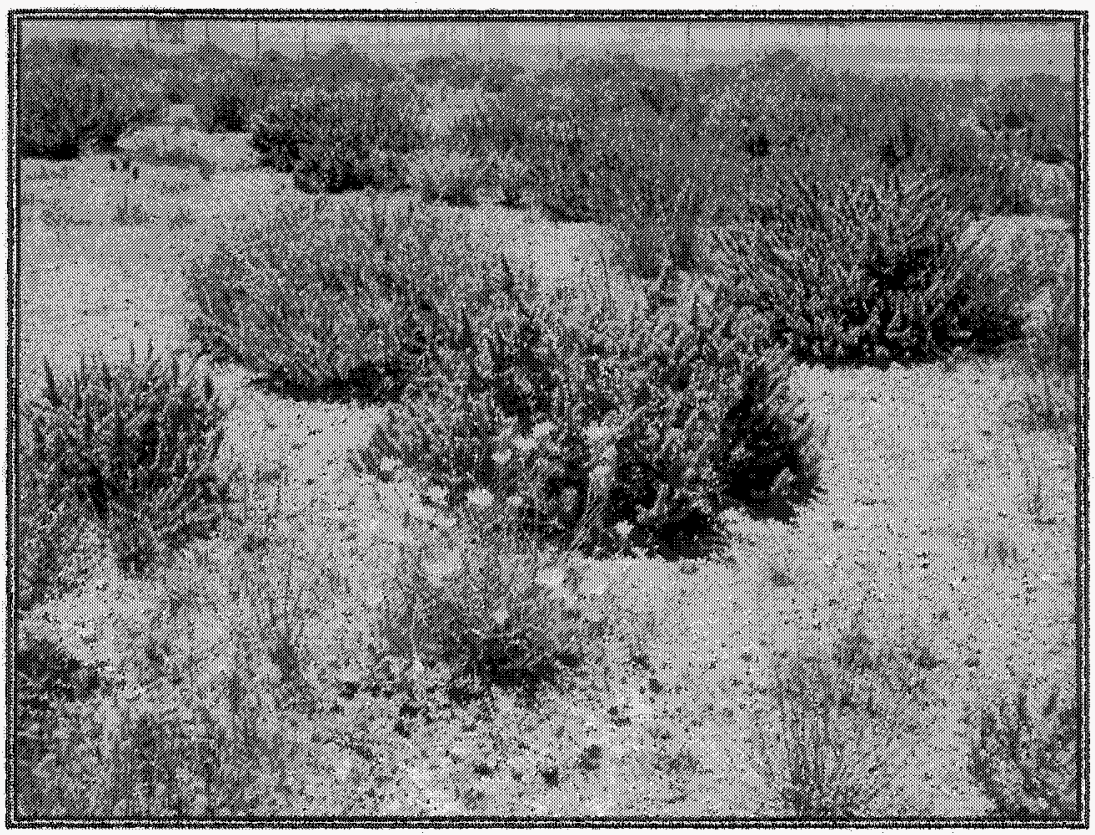

Figure 4. Smovth desertandelion with backgroumd of shadscale plants and Nevada ephedra in foreground on the U.3ax/bl clasure cover. May 17, 2005.

\section{RESULTS OF SMALL MAMMAL TRAPPING AND RELOCATION}

In April and June of 2005 , a rapping task was initiated to remove burrowing animals from the closure cover. Between April 12 and April 21 , wo trapping sessions of three consecutive trap nights per session were conducted. A total of 130 animals were removed from the closure cover and relocated approximately 5 miles from the site. During the week of June 14 , another trapping session of three consecutive nights was conducted, and 26 animals were captured and relocated (Table 3).

Table 3. Results of small mammal trapping sessions on U-3axhlol closure cover in 2005.

\begin{tabular}{|c|c|c|c|c|c|c|c|c|c|}
\hline & \multicolumn{3}{|c|}{ April 12-14, 19-21, 2005 } & \multicolumn{3}{|c|}{ June 14-16,2005 } & \multicolumn{3}{|c|}{ Total } \\
\hline & Corer & Periphery & Total & Corex & Peviphery & Total & Cover & Periphery & Tota \\
\hline $\begin{array}{l}\text { Merriam's } \\
\text { Kangaroo Ret } \\
\text { Longtalled }\end{array}$ & $\$$ & 42 & 99 & $\$$ & 13 & 18 & 62 & 555 & 18 \\
\hline Pocketmouse & 1 & 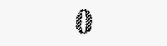 & 1 & 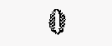 & 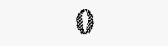 & n & 1 & (n) & 1 \\
\hline Deer Mouse & $\frac{13}{71}$ & $\frac{17}{59}$ & $\frac{30}{1.30}$ & $\frac{8}{13}$ & $\frac{0}{13}$ & $\frac{8}{26}$ & $\frac{21}{84}$ & $\frac{17}{72}$ & $\frac{38}{156}$ \\
\hline
\end{tabular}




\section{SUMMARY}

Total plant cover increased from 12.8 percent in 20041020.2 percent in 2005 . This is a good indication that native plant species on the closure cover have successfully survived the drought conditions that followed reseeding in 2000 . The almost 8 percent increase in plant cover this year is mainly attributable to increases in peremial plant cover. Perennial plant cover is 17 percent this year, a signifle ant increase over the 2 percent just two ycars ago. In contrast, there was only a slight (0.2 percent) increase in annual plant cover from 2004 to 2005 . There was a flush of growth of native anmual plants this spring in adjacent native plant communities. However, only a few of those species have established on the closure cover. Annual plant cover was essentially non-existent the first tew years after reseeding and still accounts for less than 4 percent of the total plant cover, even with near normal and above nomal annual precipiation the last two years. With time, more native amnual species may invade the site and may contribute more to the overall plant cover.

The trend in wotal plant cover over the last 4 years is as would be expected. After an initial flush of growth the second year after reseeding, due primarily to supplemental inigation, plant cover declined in 2003 (Figure 5). Natural precipitation was below normal in 2003, as it had been in 2001 and 2002. Without supplemental irrigation, germination would have been less successful, and total plant cover would probably have been even lower than what was experienced the first three years after reseeding. It is due to the 17 percent plant cover this year that the native plant community on the closure cover is viable and able to endure the fluctuations in precipitation that is more typical than atypical for this region (Figures $8-12$ ). The species of plants used in the revegetation process

\section{PLANT COVER}

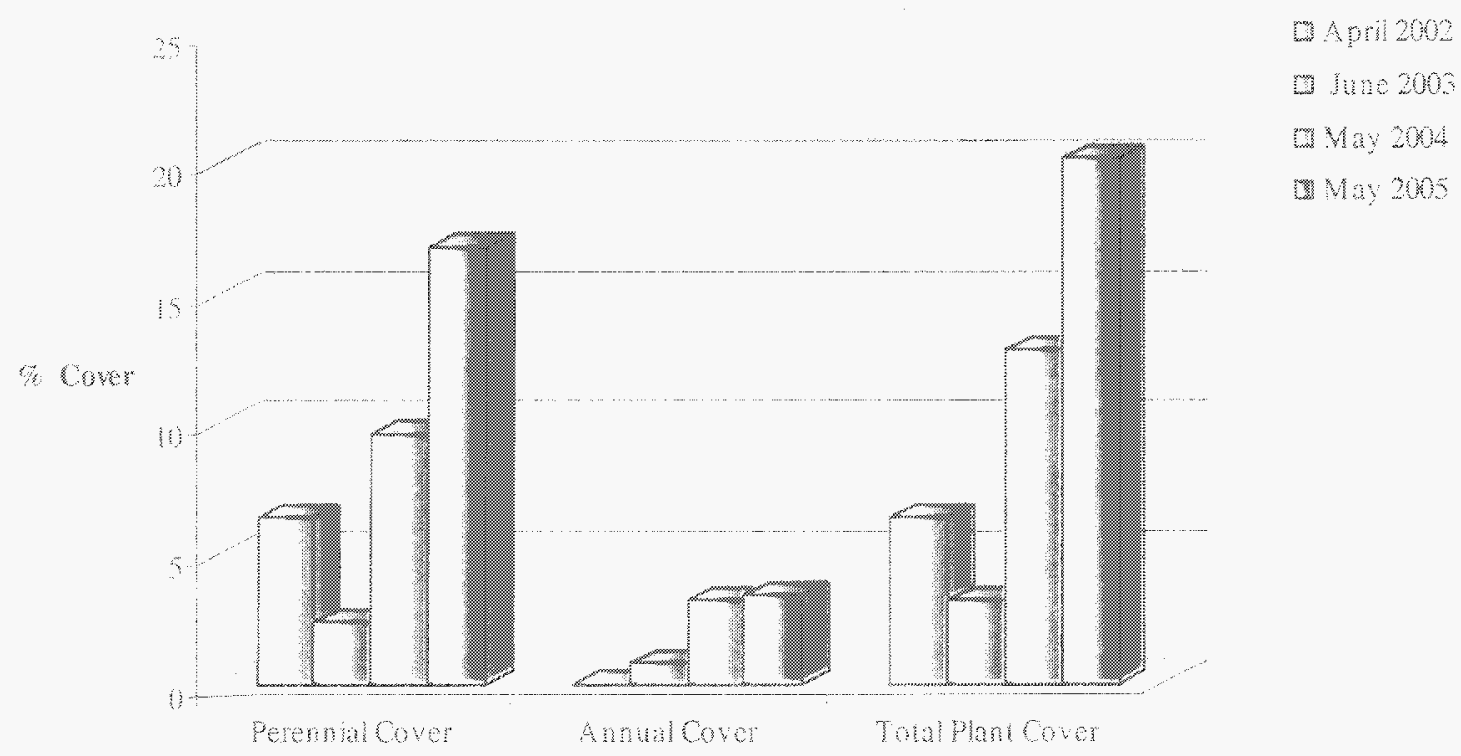

Figure 5. Summary of total plant cever on the U-3axhl closure cover hom april 2002 to May 2005. 
are native to this type of environment and have endured the drought conditons experienced the first several years after reseeding occurred. There may be decreases in plant cover in the future.

However, is is evident from the trend in plant cover (Figure 5) that although plant cover may deche under adverse growing conditions, when growing conditions do improve there is a corresponding response from the native plants present on the closure cover.

Based on revegetation efforts in similar ecoregions, which is a transition between the Mojave desert and Great Basin, a goal of 12 percent plant cover after five years was tastablished. This does not represent the final plant cover expected on the cover cap, but an intermediate stage. The five-year goal was met this year and even exceeded. Actual total plant cover is 20 percent, and the majority (17 percent) is attributable to perennial native plants, plants that are active for much of the year, unlike the 4 to 6 weeks of growth for annul plants. Eventually, plant cover should approach 25 percent bated on the results of cover estimates for similar plant communities on the Nevada Test Site. Sampliny was completed nearly two decades ago, and cover values for a shadscale/winterat plant communty were estimated to range from $16-25$ percent, goal attainable in the near future for U-3ax $/ \mathrm{bl}$.

Data from the unseeded areas along the periphery of the closure cover suggests that if the closure cover had not been seeded the composition of plant cover would have been entirely annual plants, most of them weedy, non-native species (Figure 3). Amual plant cover (Table 1) may be the same or even higher, like this year, but typically cover from annal plants lasts just a few weeks during the year. During periods of drought, as experienced from 2001 to 2003 , there were no annual plants to protect the surface soils or to remove even the smallest amounts of soil moisture.

For the third consecutive year, plant density has not changed significantly and remains at approximately 4.5 plants/m ${ }^{2}$ (Figure 6). Such a trend suggests that the plants on the closure cover are well established and utilization of available resources has been optimized. For the most part the vegetative cover on the closure cover is homogeneous, with shadscale dominating. "There are a few areas, primarily along the westem edge of the closure cover, where the densiny of winterfat, Nevada ephedra, and Indian ricegrass appears higher and shadscale is less dominant.

Shadscale, winterfat, and Indian ricegrass have shown healthy growth this year (Figure 7). Plants are flowering and will eventually set seed. There is evidence of die-of of a few shadscale plants, but it appears the die-off occurred the first or second year after reseeding because the density of this species has not significantly changed over the last three years. The sight decrease in the density of shadscale was offet with equally slght increases in the density of winterfat, Nevada ephedra, and Indian ricegrags:

The densify of annual plants increased to $100 \mathrm{plants} / \mathrm{m}^{2}$ this year, 20 plants $/ \mathrm{m}^{2}$ more than last year. Interestingly, the increase in density is not associated with an increase in cover. Cover increased by less than 1 percent, suggesting that the armual plants are more numerous but smaller. Although annual plants may be smaller, the increase is of some concem because halogeton and cheatgrass account for much of the increase. Both cheatgrass and halogeton are non-native annual plants which quickly invade disturbed sives. Both species experienced a four-fold increased in plant density from 2003 to 2005 . Halogeton is typically a poor competitor, and as native peremial plants become established, halogeton is unable to compete for resources, and densities remain low and 
insignificant. No direct impact due to the increased density of halogeton was observed on the closure cover this year. Cheatgrass, unlike halogeton, can be very competitive and can form dense patches of vegetation. These dense patches use up limited resources (soil moisture and nutrients) choking out native perennial species. In years of abundant growth, such as 2005 , these patches of cheatgrass provide fine fuels for wildland fires.

\section{PLANT DENSITY}

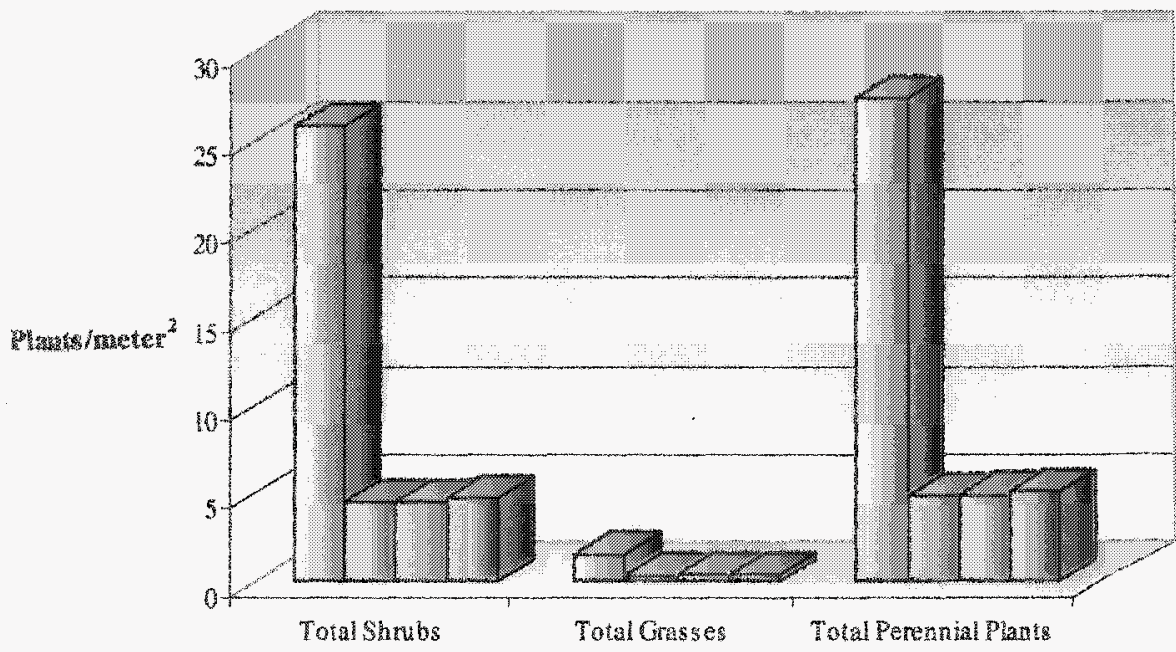

2. Aprin 2002

D. June 2003

May 2004

May 2005

Figure 6. Sumwary of peremial plant density on the U.3as/bl closure cover from April 2002 to May 2005.

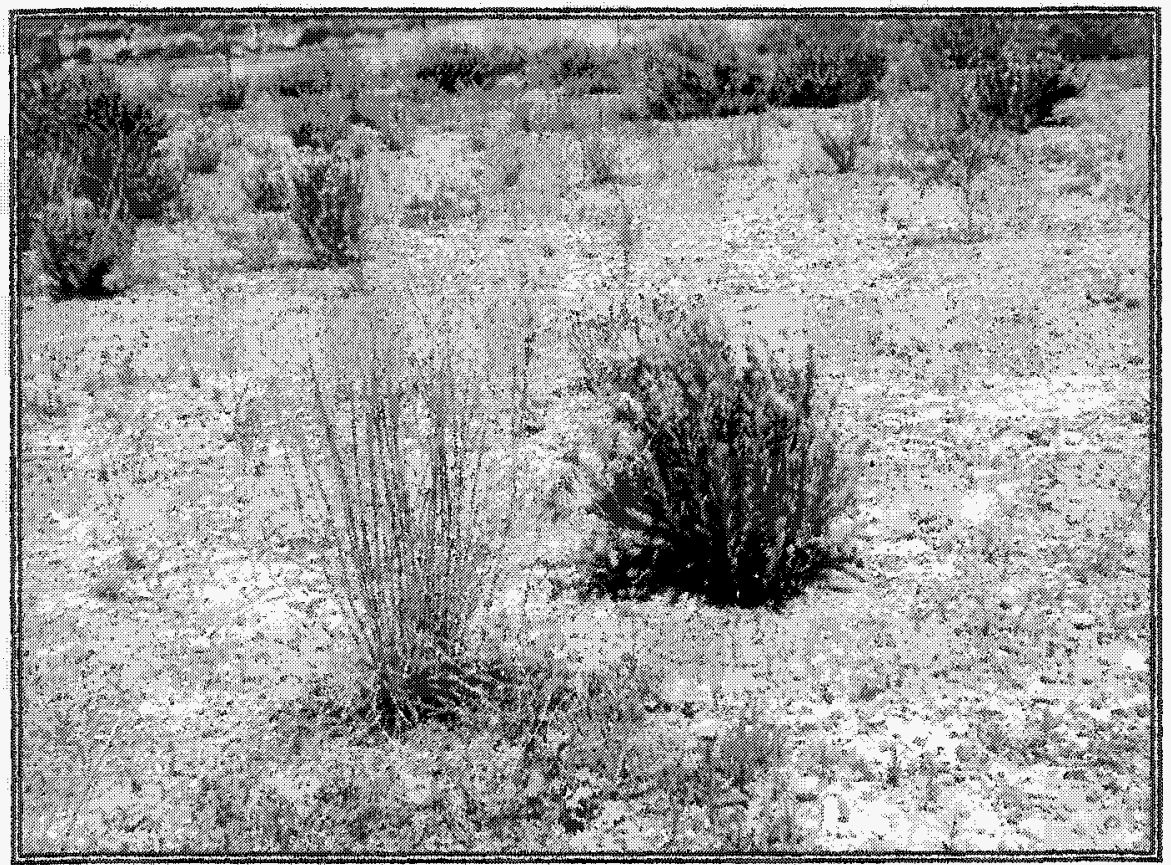

Tigure 7. Indian micegrass, on left, and winter at, on right, in wull how er/early seed. May 17, 2005 
The plant community on the closure cover is becoming well cstablished. The density of perenial plant species has remaned the same over the last thre years. Plan cover has increased to over 20 percent. well above the god of 12 percent. There is no indication that remedial revegetation is necessary. Vegetation monitoring in future years should focus on annual weedy species, specifically hogeton, cheatgrass. and Russian thiste. If these species increase in density and cover, and appear to have a detrimental effect on the permial plant spectes, as evidenced by decreases in prenna plan cover andor densily, some remedial action may be necessary to protect the compositin and stabily of the vegetative cover on the U-3ax/bl closure cover.

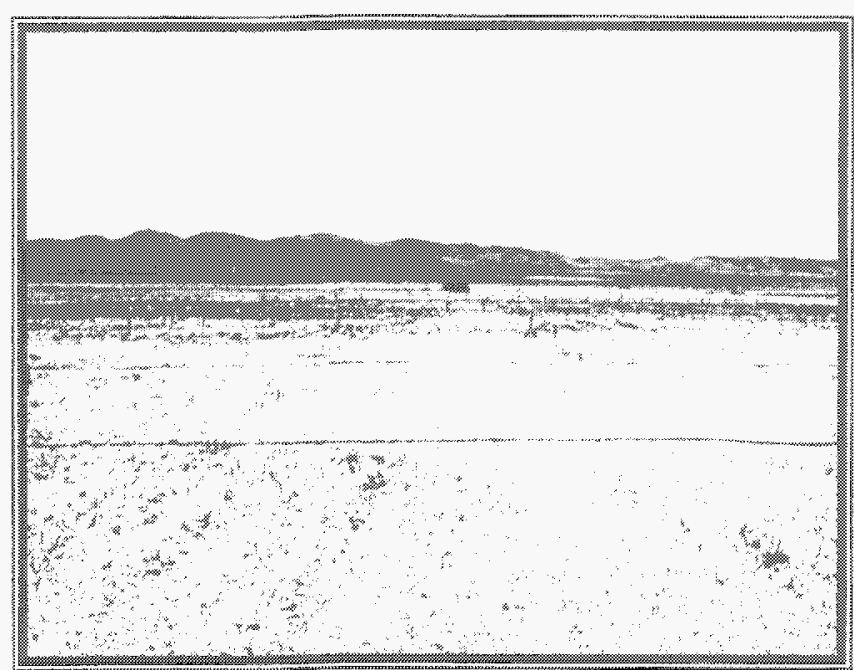

Figure 8. Closure cover: June 2001 , looking east from center of cover.

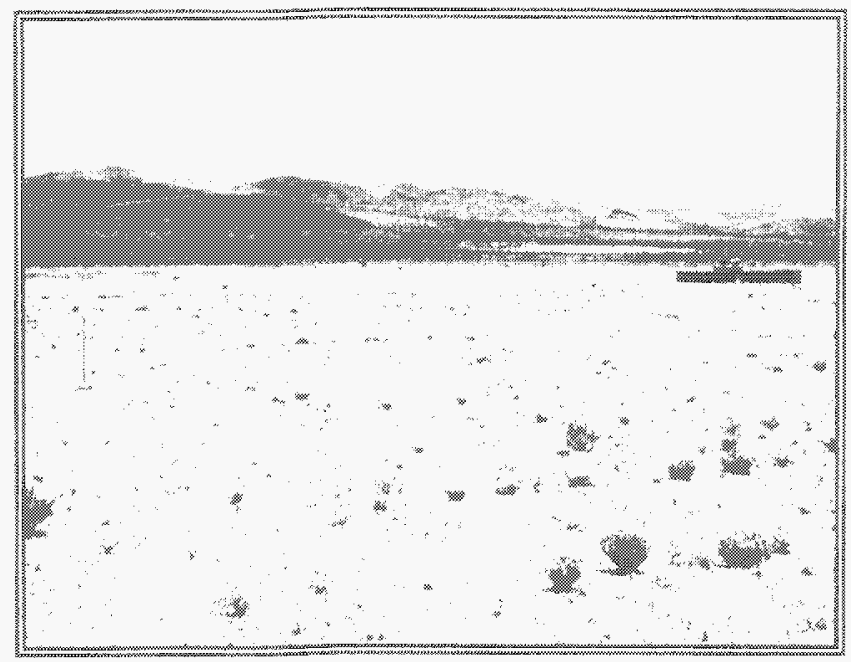

Higure 9. Closure cover: June 2002, looking southeast from center of cover.

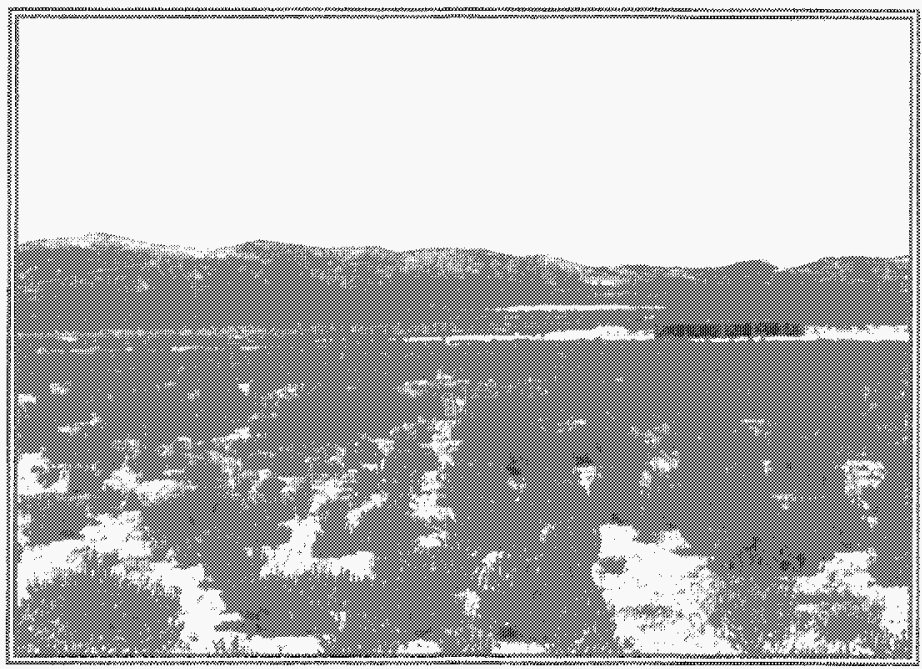

Figure 10. Closure cover: June 2005 , looking southeast frum center of cover. 


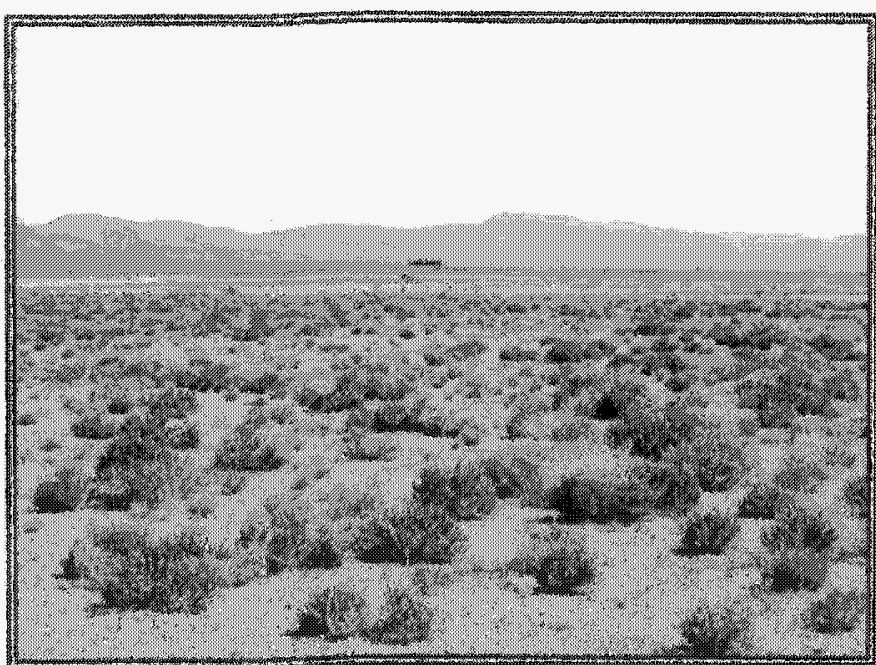

ngure 11. Closure cover: May 2004, looking southeastit from conter of cover.

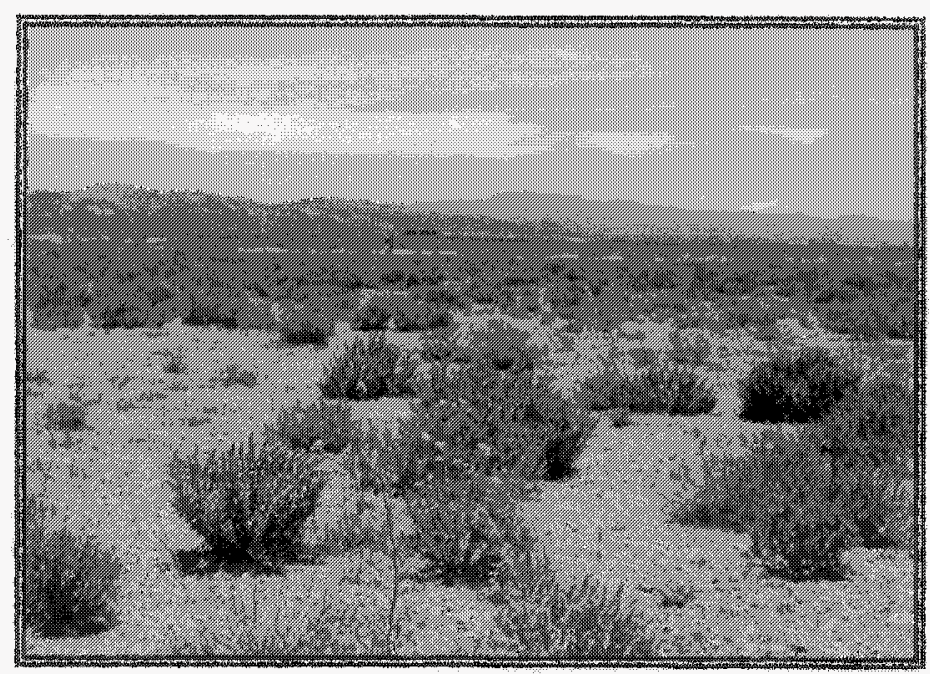

Figure 12. Closume cover: Jume 2005, looking southerast from center of cover. 
Table 4. Scientific and common names of plant species seeded or encountered on the U-3ax/bl closure cover in 2005.

\begin{tabular}{|c|c|c|}
\hline \multirow{10}{*}{$\frac{\text { Lifeform }}{\text { SHRUBS }}$} & Scientific Name & Common Name \\
\hline & $\overline{\text { Artemisia spinescens }}$ & $\overline{\text { Budsage }}$ \\
\hline & Atriplex confertifolia & Shadscale \\
\hline & Ephedra nevadensis & Nevada Ephedra \\
\hline & $\begin{array}{l}\text { Ericameria nauseosa } \\
\text { Eriognum fasciculatum }\end{array}$ & $\begin{array}{l}\text { Rubber Rabbitbrush } \\
\text { Buckwheat }\end{array}$ \\
\hline & Grayia spinosa & Spiny Hopsage \\
\hline & Hymenoclea salsola & Burrobush \\
\hline & Krascheninnikovia lanata & Winterfat \\
\hline & Lycium andersonii & Desert Thorn \\
\hline & Atriplex canescens (not seeded) & Fourwing Saltbush \\
\hline \multirow[t]{2}{*}{ GRASSES } & Achnatherum hymenoides & Indian Ricegrass \\
\hline & Elymus elymoides & Squirreltail \\
\hline FORBS & Sphaeralcea ambigua & Globemallow \\
\hline \multirow[t]{16}{*}{ ANNUALS } & Grasses & \\
\hline & Bromus rubens & Red Brome \\
\hline & Bromus tectorum & Cheatgrass \\
\hline & Schimus arabicus & Mediterranean grass \\
\hline & Forbs & \\
\hline & Amsinckia tessellata & Bristly fiddleneck \\
\hline & Chaenactis stevioides & Steve's dustymaiden \\
\hline & Cryptantha nevadensis & Nevada cateyes \\
\hline & Descurania pinnata & Tansymustard \\
\hline & Eriogonum species & Buckwheat \\
\hline & Eriogonum nidularium & Birdnest buckwheat \\
\hline & Halogeton glomerata & Halogeton \\
\hline & Malacothrix glabrata & Smooth desertdandelion \\
\hline & Mentzelia species & Blazingstar \\
\hline & Salsola tragus & Prickly Russian Thistle \\
\hline & Sisymbrium altissimum & Tall tumblemustard \\
\hline
\end{tabular}



Post-Closure Report - CAU 110

Revision: 0

Date: August 2005

\section{APPENDIX D}

\section{PRECIPITATION RECORDS}


Post-Closure Report - CAU 110

Revision: 0

Date: August 2005

THIS PAGE INTENTIONALLY LEFT BLANK 


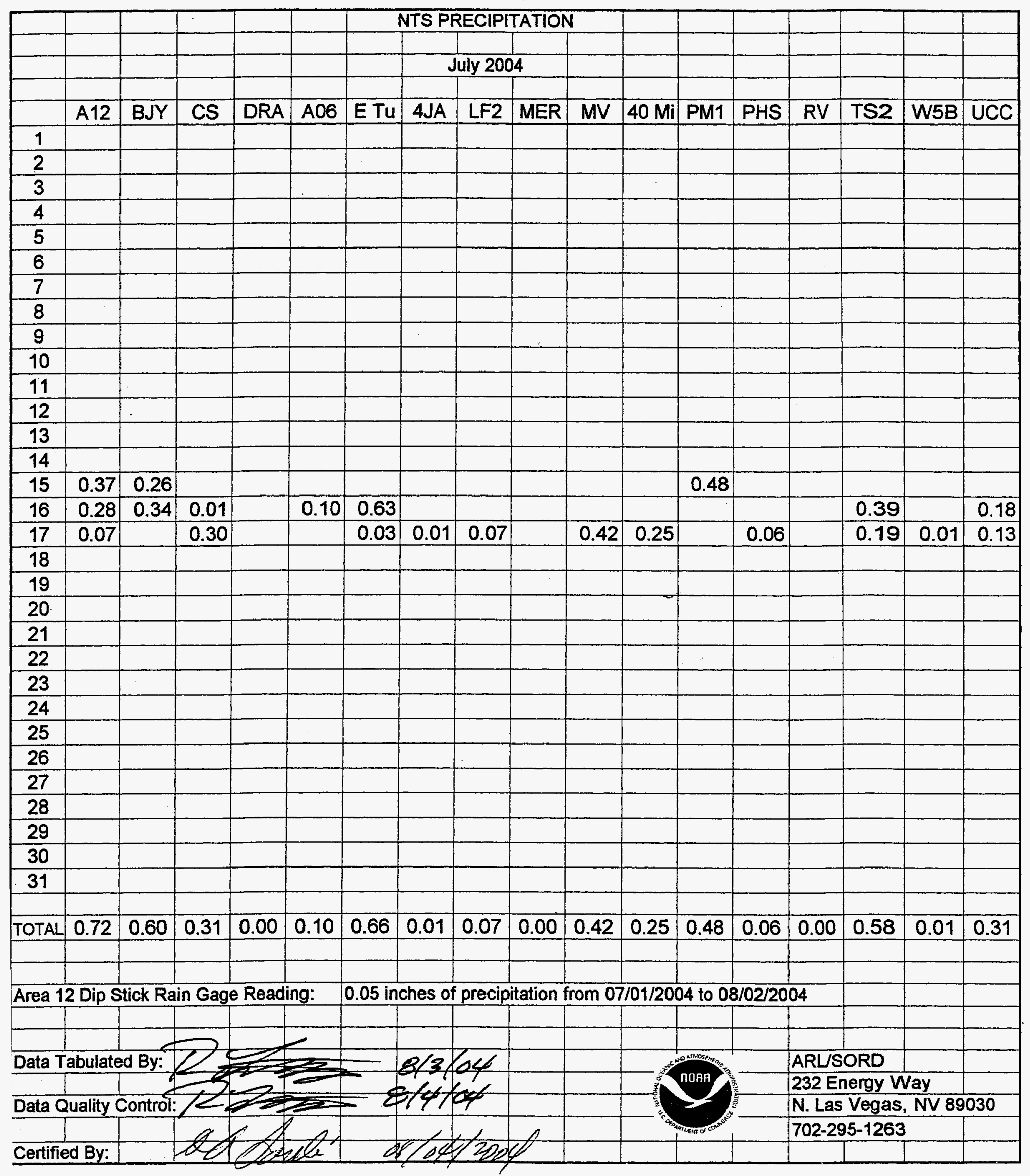




\begin{tabular}{|c|c|c|c|c|c|c|c|c|c|c|c|c|c|c|c|c|c|}
\hline & & & & & & \multicolumn{5}{|c|}{ NTS PRECIPITATION } & & & & & & & \\
\hline & & & & & & & & & & & & & & & & & \\
\hline & & & & & & & \multicolumn{3}{|c|}{ August 2004} & & & & & & & & \\
\hline & & & & & & & & & & & & & 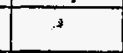 & & & & \\
\hline & $\mathrm{A} 12$ & BJY & CS & DRA & A06 & ETu & 4JA & LF2 & MER & MV & $40 \mathrm{Mi}$ & PM1 & PHS & RV & TS2 & W5B & UCC \\
\hline 1 & 0.03 & 0.06 & 0.05 & $T$ & 0.12 & 0.02 & 0.19 & 0.04 & 0.03 & 0.07 & & 0.08 & 0.04 & 0.01 & 0.11 & 0.02 & 0.05 \\
\hline 2 & 0.01 & 0.26 & 0.05 & & 0.04 & 0.01 & 0.01 & 0.01 & 0.01 & 0.01 & 0.03 & & 0.08 & 0.08 & 0.03 & 0.05 & 0.07 \\
\hline 3 & & & & & & & & & & & & & & & & & \\
\hline 4 & & & & & & & & & & & & & & & & & \\
\hline 5 & & & & & & & & & & & & & & & & & \\
\hline 6 & & & & & & & & & & & & & & & & & \\
\hline 7 & & & & & & & & & & & & & & & & & \\
\hline 8 & & & & & & & & & & & & & & & & & \\
\hline 9 & & & & & & & & & & & & & & & & & \\
\hline 10 & & & & & & & & & & & & & & & & & \\
\hline 11 & & & & & & & & & & & & & & & & & \\
\hline 12 & & & & $\mathrm{~T}$ & & & & & 0.01 & \begin{tabular}{|l|} 
\\
\end{tabular} & & & & & & & \\
\hline 13 & & & & $T$ & & & & & 0.03 & 0.17 & & 0.10 & & & & & \\
\hline 14 & 0.32 & 0.25 & 0.06 & & 0.05 & 0.12 & 0.44 & 0.18 & 0.32 & 0.25 & 0.16 & 0.05 & & 0.16 & 0.01 & & 0.05 \\
\hline 15 & 0.43 & 0.37 & 0.79 & 1.80 & 0.93 & 0.36 & 0.28 & 0.22 & 0.88 & 0.47 & 0.21 & 1.38 & 0.30 & 0.93 & 0.21 & 0.58 & 0.33 \\
\hline 16 & & & & 0.08 & & 0.01 & 0.02 & 0.01 & & 0.01 & 0.01 & 0.01 & 0.08 & & 0.06 & 0.02 & 0.02 \\
\hline 17 & & & & & & & & & & & & & & & & & \\
\hline 18 & 0.41 & 0.36 & & $\mathrm{~T}$ & & 0.39 & & & & 0.09 & 0.43 & & 0.08 & & 0.05 & & 0.17 \\
\hline 19 & & & & & & & & & & & & & & & & & \\
\hline 20 & & & & & & & & & & & & & & & & & \\
\hline 21 & 0.08 & & & & & 0.05 & & & & & & & & & & & \\
\hline 22 & & & & & & & & & & & & & & & & & \\
\hline 23 & & & & & & & & & & & & & & & & & \\
\hline 24 & & & & & & & & & & & & & & & & & \\
\hline 25 & & & & & & & & & & & & & & & & & \\
\hline 26 & & & & & & & & & & & & & & & & & \\
\hline 27 & & & & & & & & & & & & & & & & & \\
\hline 28 & & & & & & & & & & & & & & & & & \\
\hline 29 & & & & & & & & & & & & & & & & & \\
\hline 30 & & & & & & & & & & & & & & & & & \\
\hline 31 & & & & & & & & & & & & & & & & & \\
\hline & & & & & & & & & & & & & & & & & \\
\hline TOTAL & 1.28 & 1.30 & 0.95 & 1.88 & 1.14 & 0.96 & 0.94 & 0.46 & 1.28 & 1.08 & 0.84 & 1.62 & 0.58 & 1.18 & 0.47 & 0.67 & 0.69 \\
\hline & & & & & & & & & & & & & & & & & \\
\hline Area 1 & 2 Dip S & tick Ra & in Gage & e Readit & ing: & $0.80 \mathrm{inc}$ & ches of & f precipi & itation $\mathrm{f}$ & from 08 & $5 / 02 / 200$ & 24 to $0 s$ & $9 / 02 / 200$ & & & & \\
\hline & & & & & & & & & & & & & & & & & \\
\hline & & & & & & & & & & & & & & & & & \\
\hline Data T & abulate & d By: & Kag & & & & & $09 / 0$ & $3 / 200$ & & & & & & & & \\
\hline & & & & & & & & & & & & & & & & & \\
\hline Data C & uality & Sontrol: & $\mathrm{Ka}$ & & 2.0 & & & $09 / 03$ & $3 / 2004$ & & & & & & & & \\
\hline & & & & & & & & & & & & & & & & & \\
\hline Certific & d By: & & $\Delta A$ & $\mathrm{CAN}_{\triangle}$ & $m \&$ & & & $99-$ & $33-31$ & 354 & & & & & & & \\
\hline
\end{tabular}




\begin{tabular}{|c|c|c|c|c|c|c|c|c|c|c|c|c|c|c|c|c|c|}
\hline & & & & & & \multicolumn{5}{|c|}{ NTS PRECIPITATION } & & & & & & & \\
\hline & & & & & & & & & & & & & & ; & & & \\
\hline & & & & & & & \multicolumn{3}{|c|}{ September 2004} & & & & & & & & \\
\hline & A12 & BJY & CS & DRA & A06 & ETu & 4JA & LF2 & MER & MV & $40 \mathrm{Mi}$ & PM1 & PHS & RV & TS2 & W5B & UCC \\
\hline 1 & & & & & & & & & & & & & & & & & \\
\hline 2 & & & & & & & & & & & & & & & & & \\
\hline 3 & & & & 0.01 & & & & & & & & & & & & & \\
\hline 4 & & & & & & & & & & & & & & & & & \\
\hline 5 & & & & & & & & & & & & & & & & & \\
\hline 6 & & & & & & & & & & & & & & & & & \\
\hline 7 & & & & & & & & & & & & & & & & & \\
\hline 8 & & & & & & & & & & & & & & & & & \\
\hline 9 & 0.15 & 0.02 & & 0.21 & & 0.09 & & & 0.02 & & & & 0.31 & & & & \\
\hline 10 & & & & & & & & & & & & & & & & & \\
\hline 11 & 0.03 & & & 0.26 & 0.02 & 0.15 & 0.23 & & & & 0.06 & & 0.15 & 0.86 & & & 0.10 \\
\hline 12 & & & 0.03 & & 0.02 & & 0.12 & & 0.02 & & & & & 0.07 & & 0.06 & 0.02 \\
\hline 13 & & & & & & & & & & & & & & & & & \\
\hline 14 & & & & & & & & & & & & & & & & & \\
\hline 15 & & & & & & & & & & & & & & & & & \\
\hline 16 & & & & & & & & & & & & & & & & & \\
\hline 17 & & & & & & & & & & & & & & & & & \\
\hline 18 & & & & & & & & & & & & & & & & & \\
\hline 19 & & & & & & & & & & & & & & & & & \\
\hline 20 & & & & & & & & & & & & & & & & & \\
\hline 21 & & & & & & & & & & & & & & & & & \\
\hline 22 & & & & & & & & & & & & & & & & & \\
\hline 23 & & & & & & & & & & & & & & & & & \\
\hline 24 & & & & & & & & & & & & & & & & & \\
\hline 25 & & & & & & & & & & & & & & & & & \\
\hline 26 & & & & & & & & & & & & & & & & & \\
\hline 27 & & & & & & & & & & & & & & & & & \\
\hline 28 & & & & & & & & & & & & & & & & & \\
\hline 29 & 0.13 & & & & & 0.05 & & & & 0.28 & 0.02 & & & & & & 0.19 \\
\hline 30 & 0.02 & & & $\mathrm{~T}$ & 0.01 & 0.03 & & 0.04 & & 0.03 & 0.08 & & 0.12 & & 0.08 & & 0.02 \\
\hline & & & & & & & & & & & & & & & & & \\
\hline TOTAL & 0.33 & 0.02 & 0.03 & 0.48 & 0.05 & 0.32 & 0.35 & 0.04 & 0.04 & 0.31 & 0.16 & 0.00 & 0.58 & 0.93 & 0.08 & 0.06 & 0.33 \\
\hline & & & & & & & & & & & & & & & & & \\
\hline Area 1 & 2 Dip $s$ & tick Rai & in Gag & e Readir & & 0.00 inc & nches of & frecipi & itation $\mathrm{ff}$ & from 09 & $3 / 02 / 200$ & 04 to 10 & $0 / 01 / 200$ & & & & \\
\hline & & & & & & & & & & & & & & & & & \\
\hline & & & & & & & & & & & & & & & & & \\
\hline Data T & abulat & By: & & & 20 & zan & min & $10 / \mathrm{k}$ & $64 / 04$ & & & & & & & & \\
\hline & & & & & & & & & & & & & & & & & \\
\hline Data C & Quality & Control: & & & 10 & Len & mini & 101 & 10410 & & & & & & & & \\
\hline & & & & $n^{2}$ & & & & $(9)$ & $\operatorname{kit}$ & 0 & & & & & & & \\
\hline Certifie & By: & & & & & & & 2074 & & 007 & & & & & & & \\
\hline
\end{tabular}




\begin{tabular}{|c|c|c|c|c|c|c|c|c|c|c|c|c|c|c|c|c|c|}
\hline & & & & & & \multicolumn{5}{|c|}{ NTS PRECIPITATION } & & & & & & & \\
\hline & & & & & & & & & & & & & & , & & & \\
\hline & & & & & & & \multicolumn{3}{|c|}{ October 2004} & & & & & & & & \\
\hline & & & & & & & & & & & & & & & & & \\
\hline & $\mathrm{A} 12$ & BJY & CS & DRA & A06 & E Tu & 4JA & LF2 & MER & MV & $40 \mathrm{Mi}$ & PM1 & PHS & RV & TS2 & W5B & UCC \\
\hline 1 & 0.04 & & & & & & & 0.01 & & & 0.02 & & 0.02 & & & & \\
\hline 2 & & & & & & & & & & & & & & & & & \\
\hline 3 & & & & & & & & & & & & & & & & & \\
\hline 4 & & & & & & & & & & & & & & & & & \\
\hline 5 & & & & & & & & & & & & & & & & & \\
\hline 6 & & & & & & & & & & & & & & & & & \\
\hline 7 & & & & & & & & & & & & & & & & & \\
\hline 8 & & & & & & & & & & & & & & & & & \\
\hline 9 & & & & & & & & & & & & & & & & & \\
\hline 10 & & & & & 0.03 & & & & & & & & & & & & \\
\hline 11 & & & & 0.01 & & & & & & & & & & & & & \\
\hline 12 & & & & & & & & & & & & & & & & & \\
\hline 13 & & & & & & & & & & & & & & & & & \\
\hline 14 & & & & & & & & & & & & & & & & & \\
\hline 15 & & & & & & & & & & & & & & & & & \\
\hline 16 & & & & & & & & & & & & & & & & & \\
\hline 17 & & & & & & & & & & & & & & & 0.02 & & \\
\hline 18 & & & & & & & & & & & & & & & 0.01 & & \\
\hline 19 & 0.78 & 0.76 & 1.43 & 0.21 & 0.47 & 1.00 & 0.65 & 0.57 & 0.38 & 2.13 & 1.54 & 0.50 & 0.56 & 1.15 & 1.38 & 0.46 & 0.48 \\
\hline 20 & 0.65 & 0.56 & 1.37 & 1.40 & 1.31 & 1.00 & 1.04 & 0.75 & 1.07 & \begin{tabular}{|l|}
1.59 \\
\end{tabular} & 1.32 & 0.05 & 1.00 & 1.25 & 0.99 & 0.72 & 1.25 \\
\hline 21 & 0.21 & 0.03 & 0.10 & 0.17 & & 0.22 & 0.17 & 0.10 & 0.17 & 0.13 & 0.08 & 0.11 & 0.14 & 0.17 & 0.09 & 0.11 & 0.11 \\
\hline 22 & 0.02 & & 0.01 & & & 0.01 & & 0.01 & & & 0.02 & & & & 0.10 & & 0.02 \\
\hline 23 & & & & & & & & & & & & & & & & & \\
\hline 24 & 0.16 & 0.01 & 0.19 & & 0.27 & 0.07 & 0.01 & 0.09 & & & & 0.20 & & 0.26 & & & \\
\hline 25 & & 0.02 & 0.10 & $T$ & & 0.02 & 0.04 & 0.02 & & & & 0.02 & 0.06 & & & 0.02 & 0.16 \\
\hline 26 & 0.11 & 0.27 & 0.19 & & 0.04 & & 0.25 & 0.10 & & & 0.58 & 0.20 & 0.04 & 0.48 & 0.22 & 0.20 & \\
\hline 27 & 1.07 & 0.63 & 0.74 & 0.68 & 0,62 & 1.19 & 0.42 & 1.13 & 0.54 & 0.68 & 0.75 & 0.37 & 0.96 & 0.42 & 0.66 & 0.34 & 0.82 \\
\hline 28 & 0.11 & 0.02 & 0.12 & 0.02 & 0.01 & 0.19 & 0.01 & 0.22 & 0.03 & 0.07 & 0.15 & 0.05 & 0.22 & & 0.04 & & 0.03 \\
\hline 29 & & & 0.01 & & & & 0.01 & & & & 0.03 & & & & & 0.01 & \\
\hline 30 & 0.01 & & 0.01 & & & & 0.01 & & & & & & & & & & \\
\hline 31 & 0.01 & & & & & & & & & & & & & & & & \\
\hline TOTAL & 3.17 & 2.30 & 4.27 & 2.49 & 2.75 & 3.70 & 2.61 & 3.00 & 2.19 & 4.60 & 4.49 & 1.50 & 3.00 & 3.73 & 3.51 & 1.86 & 2.87 \\
\hline & & & & & & & & & & & & & & & & & \\
\hline & & & & & & & choc & & & & & & & & & & \\
\hline Area 1 & 2 Dips & tick Rai & in Gage & e Readi & & $3.10 \mathrm{inc}$ & iches of & precipi & itation $f$ & from 10 & $101 / 200$ & 04 to 11 & $1 / 01 / 200$ & & & & \\
\hline & & & & & & & & & & & & & & & & & \\
\hline Data T & abulate & d By: & & & & & & 12 & 1031 & 2004 & & & & & & & \\
\hline & & & & & & & & & & & & & & & & & \\
\hline Data Q & uality & Eontrol: & then & 2 & & & & $12 / c$ & $03 / 2$ & 004 & & & & & & & \\
\hline & & & & & & & & & & & & & & & & & \\
\hline Certifie & d By: & & Leng & $\cos 5$ & 1. $d v$ & mél & & $12 t$ & $z z-1$ & 4 & & & & & & & \\
\hline
\end{tabular}




\begin{tabular}{|c|c|c|c|c|c|c|c|c|c|c|c|c|c|c|c|c|c|}
\hline & & & & & & \multicolumn{5}{|c|}{ NTS PRECIPITATION } & & & & & & & \\
\hline & & & & & & & & & & & & & & & & & \\
\hline & & & & & & & \multicolumn{3}{|c|}{ November 2004} & & & & & & & & \\
\hline & A12 & BJY & CS & DRA & A06 & ETu & $4 \mathrm{JA}$ & LF2 & MER & MV & $40 \mathrm{Mi}$ & PM1 & PHS & RV & TS2 & W5B & UCC \\
\hline 1 & 0.02 & & & & & & & & & & & & & & & & \\
\hline 2 & & & & & & & & & & & & & & & & & \\
\hline 3 & & & & & & & & & & & & & & & & & \\
\hline 4 & & & & & & & & & & & & & & & & & \\
\hline 5 & & & & & & & & & & & & & & & & & \\
\hline 6 & & & & & & & & & & & & & & & & & \\
\hline 7 & 1.08 & 0.36 & 0.21 & 0.32 & 0.23 & 1.26 & 1.20 & 0.46 & 0.30 & 0.55 & 0.74 & 0.19 & 0.42 & 0.85 & 0.75 & 0.08 & 0.24 \\
\hline 8 & 0.82 & 0.30 & 0.19 & 0.10 & 0.29 & 0.40 & 0.05 & 0.28 & 0.04 & 0.30 & 0.42 & 0.18 & 0.12 & 0.46 & 0.35 & 0.10 & 0.46 \\
\hline 9 & & & & & & & & & & & 0.01 & & & & 0.01 & & \\
\hline 10 & & & & & & & & & & & 0.01 & & & & 0.01 & & \\
\hline 11 & & & & & & & & & & & & & & & & & \\
\hline 12 & & & & & & & & & & & & & & & & & \\
\hline 13 & & & & & & & & & & & & & & & & & \\
\hline 14 & & & & & & & & & & & & & & & & & \\
\hline 15 & & & & & & & & & & & & & & & & & \\
\hline 16 & & & & & & & & & & & & & & & & & \\
\hline 17 & & & & & & & & & & & & & & & & & \\
\hline 18 & & & & & & & & & & & & & & & & & \\
\hline 19 & & & & & & & & & & & & & & & & 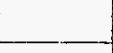 & \\
\hline 20 & 0.01 & & & & & & & & & & & & & & & & \\
\hline 21 & 0.05 & & & $T$ & & & & & & & & & & 0.02 & & & \\
\hline 22 & 0.01 & & 0.01 & 0.04 & & & 0.01 & 0.02 & 0.05 & 0.04 & 0.02 & & 0.02 & 0.02 & & 0.01 & \\
\hline 23 & & & & & & & & & & & & & & & & & \\
\hline 24 & & & & & & & & & & & & & & & & & \\
\hline 25 & 0.01 & & & & & & & & & & & 0.01 & & & & & \\
\hline 26 & 0.02 & & & & & & & & & & & & & & & & \\
\hline 27 & 0.08 & 0.02 & & 0.02 & 0.02 & 0.04 & 0.01 & 0.01 & & & & 0.01 & 0.05 & & & & \\
\hline 28 & & & & & & 0.02 & & & & & & 0.02 & & & & & \\
\hline 29 & & & & & & & & & & & & & & & & & \\
\hline 30 & & & & & & & & & & & & & & & & & \\
\hline & & & & & & & & & & & & & & & & & \\
\hline TOTAL & 2.10 & 0.68 & 0.41 & 0.48 & 0.54 & 1.72 & 1.27 & 0.77 & 0.39 & 0.89 & 1.20 & 0.41 & 0.61 & 1.35 & 1.12 & 0.19 & 0.70 \\
\hline & & & & & & & & & & & & & & & & & \\
\hline & & & & & & & & & & & & & & & & & \\
\hline Area 1 & 2 Dip $s$ & tick Ra & in Gage & e Readi & & $1.90 \mathrm{inc}$ & ches of & f precipi & itation $\mathrm{f}$ & from 11 & $1 / 01 / 200$ & 24 to 12 & $2 / 01 / 20$ & & & & \\
\hline & & & & & & & & & & & & & & & & & \\
\hline Data T & abulate & d By: & & & 016 & ennt & & $12 / 03$ & $\operatorname{Loy}$ & & & & & & & & \\
\hline & & & & & & & & & & & & & & & & & \\
\hline Data Q & uality & Control: & 12 & & 2 & emm & & 2103 & 104 & & & & & & & & \\
\hline & & & & & & & & & & & & & & & & & \\
\hline Certifie & d By: & & Ees & 11 & $\ln \theta$ & $y a^{\prime}$ & & $1=23$ & $\Delta \psi$ & & & & & & & & \\
\hline
\end{tabular}




\begin{tabular}{|c|c|c|c|c|c|c|c|c|c|c|c|c|c|c|c|c|c|}
\hline & & & & & & \multicolumn{5}{|c|}{ NTS PRECIPITATION } & & & & & & & \\
\hline & & & & & & & & & & & & & & & & & \\
\hline & & & & & & & \multicolumn{3}{|c|}{ December 2004} & & & & & & & & \\
\hline & A12 & BJY & CS & DRA & A06 & ETu & 4JA & LF2 & MER & MV & $40 \mathrm{Mi}$ & PM1 & PHS & RV & TS2 & W5B & UCC \\
\hline 1 & & & & & & & & & & & & & & & 0.02 & & \\
\hline 2 & & & & & & & & & & & & & & & 0.01 & & \\
\hline 3 & & & & & & & & & & & & & & & & & \\
\hline 4 & & & & & & & & & & & & & & & & & \\
\hline 5 & & & & & & & & & & & & & & & & & \\
\hline 6 & & & & & & 0.01 & & 0.01 & & & & & & & & & \\
\hline 7 & 0.05 & & 0.02 & $T$ & 0.01 & 0.02 & 0.01 & 0.02 & & & & & 0.03 & 0.03 & 0.02 & & \\
\hline 8 & 0.03 & & & & & 0.02 & & 0.01 & & & & & & & & & \\
\hline 9 & & & & & & 0.01 & & & & & 0.02 & & & & & & \\
\hline 10 & & & & & & & & & & & & & & & & & \\
\hline 11 & & & & & & & & & & & & & & & & & \\
\hline 12 & & & & & & & & & & & & & & & & & \\
\hline 13 & & & & & & & & & & & & & & & & & \\
\hline 14 & & & & & & & & & & & & & & & & & \\
\hline 15 & & & & & & & & & & & & & & & & & \\
\hline 16 & & & & & & & & & & & & & & & & & \\
\hline 17 & & & & & & & & & & & & & & & & & \\
\hline 18 & & & & & & & & & & & & & & & & & \\
\hline 19 & & & & & & & & & & & & & & & & & \\
\hline 20 & & & & & & & & & & & & & & & & & \\
\hline 21 & & & & & & & & & & & & & & & & & \\
\hline 22 & & & & & & & & & & & & & & & & & \\
\hline 23 & & & & & & & & & & & & & & & & & \\
\hline 24 & & & & & & & & & & & & & & & & & \\
\hline 25 & & & & & & & & & & & & & & & & & \\
\hline 26 & 0.01 & & & & & & & & & & & & & & & & \\
\hline 27 & 0.01 & 0.01 & & & & & & & & & & & & 0.01 & & & 0.01 \\
\hline 28 & 2.07 & 1.31 & 1.72 & 0.59 & 1.27 & 1.64 & 1.57 & 1.72 & 1.27 & 1.81 & 1.91 & 0.18 & 1.48 & 1.67 & 2.00 & 0.60 & 0.74 \\
\hline 29 & 0.40 & 0.08 & 0.05 & 0.97 & 0.03 & 1.36 & & 0.30 & 0.01 & 0.43 & 0.14 & 0.21 & 0.33 & 0.03 & 0.20 & 0.52 & 0.86 \\
\hline 30 & 0.01 & & & & & & & 0.02 & & 0.02 & 0.02 & & 0.01 & & 0.01 & & \\
\hline 31 & 0.16 & 0.03 & 0.07 & $T$ & 0.06 & 0.08 & 0.01 & 0.12 & 0.02 & 0.06 & 0.14 & & 0.06 & 0.02 & 0.17 & 0.02 & 0.03 \\
\hline & & & & & & & & & & & & & & & & & \\
\hline TOTAL & 2.74 & 1.43 & 1.86 & 1.56 & 1.37 & 3.14 & 1.59 & 2.20 & 1.30 & 2.32 & 2.23 & 0.39 & 1.91 & 1.76 & 2.43 & 1.14 & 1.64 \\
\hline & & & & & & & & & & & & & & & & & \\
\hline Area 1 & $2 \mathrm{Dip} S$ & tick $\mathrm{Ra}$ & in Gag & e Readi & ing: & $7.20 \mathrm{in}$ & ches of & precipi & itation $f$ & from 12 & $2 / 01 / 200$ & 04 to 01 & $1 / 20 / 200$ & & & & \\
\hline & & & & & & & & & & & & & & & & & \\
\hline & hulat & $D_{*}$ & & & & 10 & & & & & & & & & & & \\
\hline Dald I & avulate & $0 \mathrm{ay}$. & & & 20 & we & $\sim$ & & $2 / 6.4$ & $y=5$ & & & & & & & \\
\hline Data C & uality & Control: & & & 20.2 & Qen & $i$ & & 2104 & 105 & & & & & & & \\
\hline & & & & & & & & & & & & & & & & & \\
\hline Certifit & d By: & & & 11 & $S_{2}$ & & & 3 & $2 / 48$ & 200 & & & & & & & \\
\hline
\end{tabular}




\begin{tabular}{|c|c|c|c|c|c|c|c|c|c|c|c|c|c|c|c|c|c|}
\hline & & & & & & & \multicolumn{5}{|c|}{ NTS PRECIPITATION } & & & & & & \\
\hline & & & & & & & & & & & & & & & & & \\
\hline & & & & & & & & \multicolumn{3}{|c|}{ January 2005} & & & & & & & \\
\hline & & & & & & & & & & & & & & & & & \\
\hline & A12 & BJY & CS & A06 & DRA & ETu & 4JA & $40 \mathrm{Mi}$ & LF2 & MER & MV & PM1 & PHS & $\mathrm{RV}$ & TS2 & W5B & UCC \\
\hline 1 & & & & 0.01 & & 0.02 & & 0.04 & 0.04 & 0.02 & 0.01 & & 0.02 & & 0.02 & 0.02 & 0.03 \\
\hline 2 & & & & 0.01 & & & 0.01 & & & 0.01 & & & 0.01 & & 0.01 & 0.01 & 0.02 \\
\hline 3 & 1.18 & 0.37 & 0.55 & 0.54 & 0.31 & 0.60 & 0.58 & 0.43 & 0.20 & 0.35 & 0.40 & 0.11 & 0.29 & 0.57 & 0.62 & 0.02 & 0.35 \\
\hline 4 & 0.05 & 0.30 & 0.14 & 0.01 & 0.25 & 0.07 & 0.08 & 0.25 & 0.18 & 0.07 & 0.21 & 0.17 & 0.44 & 0.12 & 0.22 & 0.23 & 0.27 \\
\hline 5 & 0.02 & & 0.02 & & 0.05 & & & 0.04 & 0.03 & & & & & & 0.02 & & \\
\hline 6 & & & & & 0.01 & & & 0.25 & 0.03 & & & & & & 0.05 & & \\
\hline 7 & 0.79 & 0.52 & 0.62 & 0.37 & 0.23 & 0.55 & 0.35 & & 0.52 & 0.29 & 0.87 & & 0.65 & 0.38 & 0.93 & 0.22 & 0.39 \\
\hline 8 & 0.85 & 0.01 & 0.28 & 0.09 & 0.04 & 0.10 & 0.05 & 0.10 & 0.39 & 0.11 & 0.05 & 0.12 & 0.24 & 0.10 & 0.15 & 0.02 & 0.09 \\
\hline 9 & 1.05 & 0.22 & & 0.05 & 0.15 & 0.43 & 0.13 & 0.27 & 0.34 & 0.11 & 0.72 & 0.03 & 0.16 & 0.17 & 0.17 & & 0.02 \\
\hline 10 & 0.80 & 0.10 & 0.90 & 0.21 & 0.17 & 0.50 & 0.09 & 0.22 & 0.34 & 0.44 & 0.49 & 0.40 & 0.15 & 0.21 & 0.26 & 0.20 & 0.16 \\
\hline 11 & 0.33 & & 0.02 & 0.01 & 0.08 & 0.15 & & 0.05 & 0.23 & & 0.02 & 0.17 & 0.05 & & 0.01 & 0.02 & 0.04 \\
\hline 12 & & & & & & & & & & & & & & & & & \\
\hline 13 & & & & & & & & & & & & & & & & & \\
\hline 14 & & & & & & & & & & & & & & & & & \\
\hline 15 & & & & & & & & & & & & & & & & & \\
\hline 16 & & & & & & & & & & & & & & & & & \\
\hline 17 & & & & & & & & & & & & & & & & & \\
\hline 18 & & & & & & & & & & & & & & & & & \\
\hline 19 & & & & & & & & & & & & & & & & & \\
\hline 20 & & & & & & & & & & & & & & & & & \\
\hline 21 & & & & & & & & & & & & & & & & & \\
\hline 22 & & & & & & & & & & & & & & & & & \\
\hline 23 & & & & & & & & & & & & & & & & & \\
\hline 24 & 0.02 & & & & & 0.02 & & & 0.20 & & & 0.10 & & & 0.04 & & \\
\hline 25 & 0.01 & & & & $T$ & 0.03 & & 0.17 & 0.10 & & 0.01 & 0.05 & & & & & \\
\hline 26 & 0.70 & 0.40 & 0.48 & 0.33 & 0.27 & 0.80 & 0.65 & 0.47 & 0.69 & 0.19 & 0.57 & 0.53 & 0.53 & 0.33 & 0.90 & 0.26 & 0.32 \\
\hline 27 & 0.05 & & 0.02 & & 0.01 & 0.02 & 0.01 & 0.03 & 0.03 & 0.01 & 0.02 & 0.12 & 0.02 & 0.02 & 0.02 & 0.02 & 0.20 \\
\hline 28 & 0.27 & 0.14 & 0.07 & 0.01 & 0.01 & 0.15 & 0.08 & 0.17 & 0.21 & & 0.06 & & 0.07 & 0.15 & 0.12 & 0.03 & 0.11 \\
\hline 29 & 0.05 & & 0.02 & & 0.05 & 0.01 & & 0.08 & 0.06 & 0.09 & 0.01 & 0.11 & 0.01 & & 0.02 & & 0.03 \\
\hline 30 & & & & 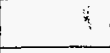 & & & & & & & 0.03 & & & & & & \\
\hline 31 & & & & & & & & & & & & & & & & & \\
\hline & & & & & & & & & & & & & & & & & \\
\hline TOTAL & 6.17 & 2.06 & 3.12 & 1.64 & 1.63 & 3.45 & 2.03 & 2.57 & 3.59 & 1.69 & 3.47 & 1.91 & 2.64 & 2.05 & 3.56 & 1.05 & 2.03 \\
\hline & & & & & & & & & & & & & & & & & \\
\hline & & & & & & & & & & & & & & & & & \\
\hline Area 1 & $2 \mathrm{Dip} s$ & tick Ra & in $\mathrm{Gag}$ & e Read & ing: & 1.30 in & ches of & f precip & itation $f$ & from 0 & $120 / 20$ & 05 to 0 & $2 / 01 / 20$ & & & & \\
\hline & & & & & & & & & & & & & & & & & \\
\hline \begin{tabular}{|l|} 
Data T \\
\end{tabular} & abulate & d By: & & & 00. & be & & 02 & 1041 & 0,5 & & & & & & & \\
\hline & Luality & Control: & & & & & & $\sigma_{2}$ & $\sqrt{0410}$ & & & & & & & & \\
\hline & & & & & & & & & & & & & & & & & \\
\hline Certifie & By: & & & $\pm a$ & $D 2$ & $12^{7}$ & & 021 & 1627 & $20 x$ & & & & & & & \\
\hline
\end{tabular}




\begin{tabular}{|c|c|c|c|c|c|c|c|c|c|c|c|c|c|c|c|c|c|}
\hline & & & & & & & \multicolumn{5}{|c|}{ NTS PRECIPITATION } & & & & & & \\
\hline & & & & & & & & & & & & & & & & & \\
\hline & & & & & & & & \multicolumn{3}{|c|}{ February 2005} & & & & & & & \\
\hline & & & & & & & & & & & & & & & & & \\
\hline & A12 & BJY & CS & $\mathrm{A} 06$ & DRA & E Tu & $4 \mathrm{JA}$ & $40 \mathrm{Mi}$ & LF2 & MER & MV & PM1 & PHS & RV & TS2 & W5B & UCC \\
\hline 1 & & & & & $T$ & & & & & & & & & & & & \\
\hline 2 & & & & & & & & & & & & & & & & & \\
\hline 3 & & & & & & & & & & & & & & & & & \\
\hline 4 & & & & & & & & & & & & & & & & & \\
\hline 5 & 0.01 & & & & & & & & & & & & & & & & \\
\hline 6 & 0.01 & & & & & & & & & & & 0.1 & & & & & \\
\hline 7 & & 0.06 & & & & 0.03 & & & & & & 0.02 & 0.05 & & & 0.02 & \\
\hline 8 & & & & & & & & & & & & & & & & & \\
\hline 9 & & & & & & & & & & & & & & & & & \\
\hline 10 & & & & & & & & & & & & & & & & & \\
\hline 11 & 0.50 & 0.30 & 0.38 & 0.33 & 0.19 & 0.63 & 0.43 & 0.16 & 0.25 & 0.22 & 0.55 & 0.27 & 0.46 & 0.33 & 0.60 & 0.18 & 0.34 \\
\hline 12 & 0.06 & 0.05 & 0.02 & & 0.04 & 0.04 & 0.08 & 0.02 & 0.03 & & 0.03 & 0.04 & & 0.08 & 0.04 & & 0.06 \\
\hline 13 & & & & & & & & & & & & & & & & & \\
\hline 14 & & & & & & & & & & & & & & & & & \\
\hline 15 & 0.02 & & & & & 0.01 & & & & & & & & & & & \\
\hline 16 & & & & & & 0.01 & & & & & & & & & & & \\
\hline 17 & 0.05 & & & & $T$ & & 0.04 & & & 0.02 & & & 0.04 & & & & \\
\hline 18 & 0.65 & 0.44 & 0.64 & 0.48 & 0.63 & 0.96 & 0.41 & 0.41 & 0.55 & 0.57 & 0.55 & 0.29 & 0.82 & 0.61 & 0.60 & 0.55 & 0.52 \\
\hline 19 & 0.67 & 0.06 & 0.21 & 0.07 & 0.19 & 0.45 & 0.25 & 0.15 & 0.34 & 0.23 & 0.30 & 0.16 & 0.31 & 0.26 & 0.35 & 0.13 & 0.18 \\
\hline 20 & 0.45 & 0.01 & 0.02 & 0.14 & & 0.43 & 0.23 & 0.07 & 0.06 & 0.10 & 0.14 & 0.02 & 0.13 & & 0.19 & & 0.02 \\
\hline 21 & 1.24 & 0.82 & 0.99 & 0.51 & 0.69 & 1.53 & 0.80 & 0.97 & 1.02 & 0.39 & 1.08 & 0.26 & 1.09 & 1.29 & 1.12 & 0.41 & 0.66 \\
\hline 22 & 0.51 & 0.43 & 0.21 & 0.13 & 0.15 & 0.43 & 0.18 & 0.13 & 0.22 & 0.27 & 0.16 & 0.27 & 0.47 & 0.22 & 0.21 & 0.25 & 0.29 \\
\hline 23 & 0.41 & 0.04 & 0.13 & 0.15 & 0.06 & 0.33 & 0.09 & 0.05 & \begin{tabular}{|l|}
0.12 \\
\end{tabular} & 0.05 & 0.39 & 0.05 & 0.14 & 0.06 & 0.44 & 0.10 & 0.26 \\
\hline 24 & & 0.02 & 0.01 & 0.05 & $T$ & 0.02 & 0.03 & 0.02 & 0.01 & & 0.04 & 0.03 & & & 0.05 & 0.01 & \\
\hline 25 & 0.02 & 0.01 & & & & & 0.08 & & & & & 0.02 & & & & 0.01 & \\
\hline 26 & 0.06 & & & & 0.03 & & & & & & & & & 0.01 & & & \\
\hline 27 & & & & & & & & & & & & & & & & & \\
\hline 28 & 0.05 & & & & & 0.01 & & & & & & 0.05 & & & & & \\
\hline 29 & & & & & & & & & & & & & & & & & \\
\hline & & & & & & & & & & & & & & & & & \\
\hline & & & & & & & & & & & & & & & & & \\
\hline TOTAL & 4.71 & 2.24 & 2.61 & 1.86 & 1.98 & 4.88 & 2.62 & 1.98 & 2.60 & 1.85 & 3.24 & 1.58 & 3.51 & 2.86 & 3.60 & 1.66 & 2.33 \\
\hline & & & & & & & & & & & & & & & & & \\
\hline & & & & & & & & & & & & & & & & & \\
\hline Area 1 & $2 \operatorname{Dip} S$ & tick Rai & in Gage & e Readi & ing: & $4.50 \mathrm{in}$ & ches of & f precipi & itation $\mathrm{f}$ & rom 02 & $101 / 200$ & 55 to 03 & $3 / 01 / 200$ & & & & \\
\hline & & & & & & & & & & & & & & & & & \\
\hline Data T & abulate & d By: & & & & & & $3 / 031$ & 2005 & & & & & & & & \\
\hline & & & 0 & & & & & & & & & & & & & & \\
\hline & uality & trol: & $\leq$ & & & & & 31036 & $\sqrt{2005}$ & & & & & & & & \\
\hline & & & & & & & & & & & & & & & & & \\
\hline Certifie & $\mathrm{d} \mathrm{By}:$ & & $B Q$ & mast & & An & 4 & $93-07$ & {$[-3000$} & & & & & & & & \\
\hline
\end{tabular}




\begin{tabular}{|c|c|c|c|c|c|c|c|c|c|c|c|c|c|c|c|c|c|}
\hline & & & & & & & & NTS PF & RECIPI & TATION & & & & & & & \\
\hline & & & & & & & & & & & & & & & & & \\
\hline & & & & & & & & & $\operatorname{arch} 20$ & & & & & & & & \\
\hline & & & & & & & & & & & & & & & & & \\
\hline & $\mathrm{A} 12$ & BJY & CS & A06 & DRA & ETu & $4 \mathrm{JA}$ & $40 \mathrm{Mi}$ & LF2 & MER & $\mathrm{MV}$ & PM1 & PHS & RV & TS2 & W5B & UCC \\
\hline 1 & & & & & & & & & & & & & & & & & \\
\hline 2 & 0.02 & 0.02 & & & 0.01 & 0.05 & & 0.01 & 0.03 & & & 0.05 & 0.02 & & 0.01 & & \\
\hline 3 & & & & & & & & & & & & & & & & & \\
\hline 4 & & & & & & & & & & & & & & & & & \\
\hline 5 & & & & & & & & & & & & & & & & & \\
\hline 6 & & & & & & & & & & & & & & & & & \\
\hline 7 & & & & & & & & & & & & & & & & & \\
\hline 8 & & & & & & & & & & & & & & & & & \\
\hline 9 & & & & & & & & & & & & & & & & & \\
\hline 10 & & & & & & & & & & & & & & & & & \\
\hline 11 & & & & & & & & & & & & & & & - & & \\
\hline 12 & & & & & & & & & & & & & & & & & \\
\hline 13 & & & & & & & & & & & & & & & & & \\
\hline 14 & & & & & & & & & & & & & & & & & \\
\hline 15 & & & & & & & & & & & & & & & & & \\
\hline 16 & & & & & & & & & & & & & & & & & \\
\hline 17 & & & & & & & & & & & & & & & & & \\
\hline 18 & & & & & & & & & & & & & & & & & \\
\hline 19 & 0.09 & 0.02 & 0.02 & 0.02 & 0.02 & 0.08 & & 0.03 & 0.02 & & 0.05 & 0.02 & 0.12 & & 0.02 & 0.02 & \\
\hline 20 & & & & & & & & & & & & & & & & & \\
\hline 21 & & & & & & & & & & & & & & & & & \\
\hline 22 & 0.38 & & 0.14 & 0.04 & 0.02 & 0.37 & 0.05 & 0.10 & 0.13 & 0.05 & 0.20 & 0.35 & 0.16 & 0.05 & 0.09 & 0.01 & \\
\hline 23 & 0.12 & & & & & 0.12 & & 0.06 & 0.05 & & 0.02 & 0.08 & 0.02 & & 0.05 & 0.02 & \\
\hline 24 & 0.44 & 0.13 & 0.08 & 0.10 & 0.06 & 0.30 & & 0.16 & 0.30 & 0.21 & 0.09 & 0.31 & 0.20 & 0.15 & 0.17 & 0.06 & 0.10 \\
\hline 25 & 0.01 & & & & & 0.12 & 0.02 & 0.04 & 0.02 & & 0.02 & 0.01 & & & 0.03 & & \\
\hline 26 & & & & & & & & & & 0.04 & & & & & & & \\
\hline 27 & & & & & & & & & & & & 0.02 & & & & & \\
\hline 28 & 0.09 & 0.13 & 0.13 & 0.20 & 0.09 & 0.14 & 0.20 & 0.33 & 0.20 & 0.05 & 0.20 & 0.11 & 0.18 & 0.20 & 0.30 & 0.30 & 0.10 \\
\hline 29 & & & & & & & & & & 0.02 & & 0.01 & & & & & \\
\hline 30 & & & & & & & & & & & & & & & & & \\
\hline 31 & & & & & & & & & & & & & & & & & \\
\hline & & & & & & & & & & & & & & 0 & 007 & 014 & 070 \\
\hline TOTAL & 1.15 & 0.30 & 0.37 & 0.36 & 0.20 & 1.18 & 0.27 & 0.73 & 0.75 & 0.37 & 0.58 & 0.96 & 0.70 & 0.40 & 0.67 & 0.41 & 0.20 \\
\hline & & & & & & & & & & & & & & & & & \\
\hline Area 1 & 2 Dips & tick Ra & in $\mathrm{Gag}$ & e Read & & $1.20 \mathrm{ine}$ & ches of & f precipi & itation & from 03 & $3 / 01 / 20$ & 05 to 04 & $4 / 01 / 200$ & & & & \\
\hline & & & & & & & & & & & & & & & & & \\
\hline & & & & & & & & & & & & & & & & & \\
\hline Data T & abulate & ed By: & & & & 2 & & & $4 / 6$ & 4105 & & & & & & & \\
\hline$\overline{\text { Data C }}$ & uality & Control & & & & 20 & & L: & & 105 & & & & & & & \\
\hline & & & & & & & & & & & & & & & & & \\
\hline Certifit & d By: & & & Losa & $\operatorname{Exs} A$ & $6 \pi$ & rela 1 & & 478 & $i / 2 e s$ & $\rho$ & & & & & & \\
\hline
\end{tabular}




\begin{tabular}{|c|c|c|c|c|c|c|c|c|c|c|c|c|c|c|c|c|c|}
\hline & & & & & & & \multicolumn{5}{|c|}{ NTS PRECIPITATION } & & & & & & \\
\hline & & & & & & & & & & & & & & & & & \\
\hline & & & & & & & & \multicolumn{3}{|c|}{ April 2005} & & & & & & & \\
\hline & & & & & & & & & & & & & & & & & \\
\hline & A12 & BJY & CS & DRA & A06 & ETu & $4 \mathrm{JA}$ & LF2 & MER & MV & $40 \mathrm{Mi}$ & PM1 & PHS & RV & TS2 & W5B & UCC \\
\hline 1 & & & & & & & & & & & & & & & & & \\
\hline 2 & & & & & & & & & & & & & & & & & \\
\hline 3 & & & & & & & & & & & & & & & & & \\
\hline 4 & & 0.02 & 0.02 & 0.05 & 0.04 & & 0.04 & & & & 0.02 & & & & & & 0.02 \\
\hline 5 & & & & & & & & & & & & & & & & & \\
\hline 6 & & & & & & & & & & & & & & & & & \\
\hline 7 & & & & & & 0.02 & & & & & & & & & & & \\
\hline 8 & & 0.07 & 0.12 & 0.26 & 0.26 & 0.01 & & 0.03 & 0.40 & 0.17 & 0.06 & 0.12 & 0.08 & 0.18 & 0.05 & 0.32 & 0.29 \\
\hline 9 & 0.09 & & & & & 0.03 & & 0.01 & & & & 0.04 & & & & & \\
\hline 10 & & & & & & & & & & & & & & & & & \\
\hline 11 & & & & & & & & & & & & & & & & & \\
\hline 12 & & & & & & & & & & & & & & & & & \\
\hline 13 & & & & & & & & & & & & & & & & & \\
\hline 14 & & & & & & & & & & & & & & & & & \\
\hline 15 & & & & & & & & & & & & & & & & & \\
\hline 16 & & & & & & & & & & & & & & & & & \\
\hline 17 & & & & & & & & & & & & & & & & & \\
\hline 18 & & & & & & 0.01 & & & & & & 0.03 & & & & & \\
\hline 19 & & & 0.02 & $T$ & 0.02 & 0.01 & & & & 0.05 & 0.01 & 0.19 & 0.02 & 0.02 & & & \\
\hline 20 & & & & & & & & & & & & & & & & & \\
\hline 21 & & & & & & & & & & & & & & & & & \\
\hline 22 & & & & & & & & & & & & & & & & & \\
\hline 23 & 0.01 & 0.02 & 0.02 & & 0.02 & 0.02 & 0.02 & & & & & 0.01 & 0.02 & 0.01 & & & \\
\hline 24 & 0.02 & 0.02 & 0.02 & & 0.16 & 0.03 & 0.01 & 0.01 & & 0.14 & 0.01 & 0.01 & 0.01 & & 0.02 & 0.08 & 0.17 \\
\hline 25 & & & & & & 0.02 & & & & & & & & & & & \\
\hline 26 & & & & & & 0.07 & & & & & & & & & & & \\
\hline 27 & 0.03 & & & $T$ & & 0.01 & 0.02 & & & & & & & & & & \\
\hline 28 & 0.22 & 0.26 & 0.98 & 0.04 & 0.50 & 0.16 & 0.20 & 0.18 & 0.02 & 0.50 & 0.24 & 0.07 & 0.06 & 0.12 & 0.43 & 0.66 & 0.28 \\
\hline 29 & & & & & & & & & & & & & & & & & \\
\hline 30 & & & & & & & & & & & & & & & & & \\
\hline & & & & & & & & & & & & & & & & & \\
\hline TOTAL & 0.37 & 0.39 & 1.18 & 0.35 & 1.00 & 0.39 & 0.29 & 0.23 & 0.42 & 0.86 & 0.34 & 0.47 & 0.19 & 0.33 & 0.50 & 1.06 & 0.76 \\
\hline & & & & & & & & & & & & & & & & & \\
\hline & & & & & & & & & & & & & & & & & \\
\hline Area 1 & 2 Dip S & tick $R a$ & in $\mathrm{Gag}$ & Readi & ing: & $0.40 \mathrm{in}$ & ches of & precipi & itation $\mathrm{f}$ & from 04 & $101 / 200$ & 55 to 05 & $102 / 200$ & & & & \\
\hline & & & & & & & & & & & & & & & & & \\
\hline Data T & abulate & By: & & Rom & $2 x$ & 6. De & & 05 & 10610 & 5 & & & & & & & \\
\hline & & & & & & & & & & & & & & & & & \\
\hline Data $Q$ & uality $c$ & Control: & & Rिaym & $\operatorname{mon} v$ & 2.2 & mis & 05 & 1061 & 105 & & & & & & & \\
\hline & & & & $n$ & & & & & & & & & & & & & \\
\hline Eertifie & $\mathrm{d} B \mathrm{y}:$ & & & Q & $\operatorname{ces}$ & 21 & $2 n$ & $5 x$ & 2061 & DOS & & & & & & & \\
\hline
\end{tabular}




\begin{tabular}{|c|c|c|c|c|c|c|c|c|c|c|c|c|c|c|c|c|c|}
\hline & & & & & & & \multicolumn{5}{|c|}{ NTS PRECIPITATION } & & & & & & \\
\hline & & & & & & & & & & & & & & & & & \\
\hline & & & & & & & & \multicolumn{3}{|c|}{ May 2005} & & & & & & & \\
\hline & & & & & & & & & & & & & & & & & \\
\hline & A12 & BJY & CS & DRA & A06 & E Tu & 4JA & LF2 & MER & MV & $40 \mathrm{Mi}$ & PM1 & PHS & $\mathrm{RV}$ & TS2 & W5B & UCC \\
\hline 1 & & & & & & & & & & & & & & & & & \\
\hline 2 & 0.02 & 0.14 & 0.05 & $T$ & & 0.33 & 0.07 & & & & & 0.03 & 0.27 & 0.05 & 0.09 & 0.05 & \\
\hline 3 & & & & & & & & & & & & & & & & & \\
\hline 4 & & & & & & & & & & & & & & & & & \\
\hline 5 & 0.02 & 0.05 & 0.03 & 0.07 & 0.06 & 0.05 & 0.06 & 0.01 & 0.06 & 0.06 & 0.01 & 0.13 & 0.05 & 0.04 & 0.21 & 0.06 & 0.04 \\
\hline 6 & 0.41 & 0.27 & 0.28 & 0.19 & 0.21 & 0.51 & 0.04 & 0.50 & 0.17 & 0.23 & 0.51 & 0.43 & 0.26 & 0.07 & 0.65 & 0.17 & 0.20 \\
\hline 7 & & & & & & & & 0.01 & & & 0.01 & & & & & 0.01 & \\
\hline 8 & & & & & & & & & & & & & & & & & \\
\hline 9 & & & & & & & & & & & & & & & & & \\
\hline 10 & & & & & & & & & & & & & & & & & \\
\hline 11. & & & & & & & & & & & & & & & & & \\
\hline 12 & & & & & & & & & & & & & & & & & \\
\hline 13 & & & & & & & & & & & & & & & & & \\
\hline 14 & & & & & & & & & & & & & & & & & \\
\hline 15 & & & & & & & & & & & & & & & & & \\
\hline 16 & 0.03 & 0.03 & & & 0.04 & 0.02 & & 0.03 & & & 0.01 & & 0.17 & & & & \\
\hline 17 & & & & & & & & 0.01 & & & 0.01 & & & & & & \\
\hline 18 & & & & & & & & & & & & & & & & & \\
\hline 19 & & & & & & & & & & & & & & & & & \\
\hline 20 & & & & & & & & & & & & & & & & & \\
\hline 21 & & & & & & & & & & & & & & & & & \\
\hline 22 & & & & & & & & & & & & & & & & & \\
\hline 23 & & & & & & & & & & & & & & & & & \\
\hline 24 & & & & & & & & & & & & & & & & & \\
\hline 25 & & & & & & & & & & & & & & & & & \\
\hline 26 & & & & & & & & & & & & & & & & & \\
\hline 27 & & & & & & & & & & & & & & & & & \\
\hline 28 & & & & & & & & & & & & & & & & & \\
\hline 29 & & & & & & & & & & & & & & & & & \\
\hline 30 & & & & & & & & & & & & & & & & & \\
\hline 31 & & & & & & & & & & & & & & & & & \\
\hline & & & & & & & & & & & & & 075 & 016 & 095 & 029 & 024 \\
\hline TOTAL & 0.48 & 0.49 & 0.36 & 0.26 & 0.31 & 0.91 & 0.17 & 0.56 & 0.23 & 0.29 & 0.55 & 0.59 & 0.15 & 0.10 & 0.80 & 0.29 & 0.24 \\
\hline & & & & & & & & & & & & & & & & & \\
\hline Area 1 & 2 Dips & tick Ra & in Gage & e Read & ing: & 1.10 in & ches of & f precip & itation $f$ & rom 01 & $1 / 02 / 200$ & 55 to 02 & $2 / 02 / 20$ & & & & \\
\hline & & & & & & & & & & & & & & & & & \\
\hline & & & 1 & & & & & & & & & & & & & & \\
\hline Data T & abulat & $\mathrm{d} \mathrm{By} / \mathrm{f}$ & 16 & (a) & $Z$ & 6 & $3-05$ & & & & & & & & & & \\
\hline & & 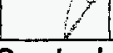 & & & & & & & & & & & & & & & \\
\hline Data Q & uaality & Control: & Rang & $m 4$ & d) & 2) 2 in & $\therefore<4$ & $\mid-03$ & -05 & & & & & & & & \\
\hline & & & & & & & & & & & & & & & & & \\
\hline Certifie & $\mathrm{By}$ : & & 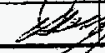 & 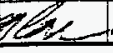 & A., & ste & of & $\log 2 x$ & 200.5 & & & & & & & & \\
\hline
\end{tabular}




\begin{tabular}{|c|c|c|c|c|c|c|c|c|c|c|c|c|c|c|c|c|c|}
\hline & & & & & & & \multicolumn{5}{|c|}{ NTS PRECIPITATION } & & & & & & \\
\hline & & & & & & & & & & & & & & & & & \\
\hline & & & & & & & & \multicolumn{3}{|c|}{ June 2005} & & & & & & & \\
\hline & & & & & & & & & & & & & & & & & \\
\hline & A12 & BJY & CS & DRA & A06 & ETu & $4 \mathrm{JA}$ & LF2 & MER & MV & $40 \mathrm{Mi}$ & PM1 & PHS & RV & TS2 & W5B & UCC \\
\hline 1 & & & & & & & & & & & & & & & & & \\
\hline 2 & & 0.05 & & & 0.02 & 0.02 & & & & 0.07 & 0.09 & 0.02 & $0: 02$ & & 0.04 & & \\
\hline 3 & & & & & & & & & & & & & & & & & \\
\hline 4 & & & & & & & & & & & & & & & & & \\
\hline 5 & & & & & & & & & & & & & & & & & \\
\hline 6 & & & & & & & & & & & & & & & & & \\
\hline 7 & & & & & & & & & & & & & & & & & \\
\hline 8 & & & & & & & & & & & & & & & & & \\
\hline 9 & 0.10 & & & & & 0.05 & & 0.15 & & 0.03 & 0.04 & 0.15 & 0.02 & & 0.03 & & \\
\hline 10 & 0.25 & 0.04 & & & & 0.20 & & 0.02 & & & 0.01 & 0.08 & 0.27 & 0.03 & 0.02 & & \\
\hline 11 & & & & & & & & & & & & & & & & & \\
\hline 12 & & & & & & & & & & & & & & & & & \\
\hline 13 & & & & & & & & & & & & & & & & & \\
\hline 14 & & & & & & & & & & & & & & & & & \\
\hline 15 & & & & & & & & & & & & & & & & & \\
\hline 16 & & & & & & & & & & & & & & & & & \\
\hline 17 & & & & & & & & & & & & & & & & & \\
\hline 18 & & & & & & & & & & & & & & & & & \\
\hline 19 & & & & & & 0.03 & & & & & & & & & & & \\
\hline 20 & & & & & & & & & & & & & & & & & \\
\hline 21 & & & & & & & & & & & & & & & & & \\
\hline 22 & & & & 0.02 & 0.06 & & & & 0.02 & & & & & & 0.02 & 0.02 & \\
\hline 23 & & & & & & & & & & & & & & & & & \\
\hline 24 & & & & & & & & & & & & & & & & & \\
\hline 25 & & & & & & & & & & & & & & & & & \\
\hline 26 & & & & & & & & & & & & & & & & & \\
\hline 27 & & & & & & & & & & & & & & & & & \\
\hline 28 & & & & & & & & & & & & & & & - & & \\
\hline 29 & & & & & & & & & & & & & & & & & \\
\hline 30 & & & & & & & & & & & & & & & & & \\
\hline & & & & & & & & & & & & & & & & & \\
\hline TOTAL & 0.35 & 0.09 & 0.00 & 0.02 & 0.08 & 0.30 & 0.00 & 0.17 & 0.02 & 0.10 & 0.14 & 0.25 & 0.31 & 0.03 & 0.11 & 0.02 & 0.00 \\
\hline & & & & & & & & & & & & & & & & & \\
\hline & & & & & & & & & & & & & & & & & \\
\hline Area 1 & 2 Dips & tick Ra & in Gag & Readi & & 0.30 in & ches of & precipi & itation $f$ & from 01 & $102 / 200$ & 55 to 0 & $2 / 02 / 200$ & & & & \\
\hline & & & & & & & & & & & & & & & & & \\
\hline Data T & abulate & By: & & & 00 & () & & & 2105 & $5 / 200$ & & & & & & & \\
\hline & 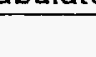 & & & & & & & & & & & & & & & & \\
\hline Data Q & uality & Control: & 62 & & 20 & Xen & $m i$ & O) & $2 / 05$ & L2005 & & & & & & & \\
\hline & & & & & & & & & & & & & & & & & \\
\hline Certifie & d By: & & $\sqrt{3}$ & ze & $\mathbb{A}$ & $d=$ & 21 & 9 & 306 & 2000t & & & & & & & \\
\hline
\end{tabular}


Post-Closure Report - CAU 110

Revision: 0

Date: August 2005

\section{LIBRARY DISTRIBUTION LIST}


Post-Closure Report - CAU 110

Revision: 0

Date: August 2005

\section{THIS PAGE INTENTIONALLY LEFT BLANK}




\section{LIBRARY DISTRIBUTION LIST}

U.S. Department of Energy

National Nuclear Security Administration

Nevada Site Office

Technical Library

P.O. Box 98518, M/S 505

Las Vegas, NV 89193-8518

U.S. Department of Energy

Office of Scientific and Technical Information

P.O. Box 62

Oak Ridge, TN 37831-0062

Southern Nevada Public Reading Facility

c/o Nuclear Testing Archive

P.O. Box $98521, \mathrm{M} / \mathrm{S} 400$

Las Vegas, NV 89193-8521

Manager, Northern Nevada FFACO

Public Reading Facility

c/o Nevada State Library \& Archives

Carson City, NV 89701-4285
1 (Uncontrolled)

1 (Uncontrolled, electronic copy)

1 (Controlled)

1 (Uncontrolled)

1 (Uncontrolled) 
Post-Closure Report - CAU 110

Revision: 0

Date: August 2005

THIS PAGE INTENTIONALLY LEFT BLANK 